
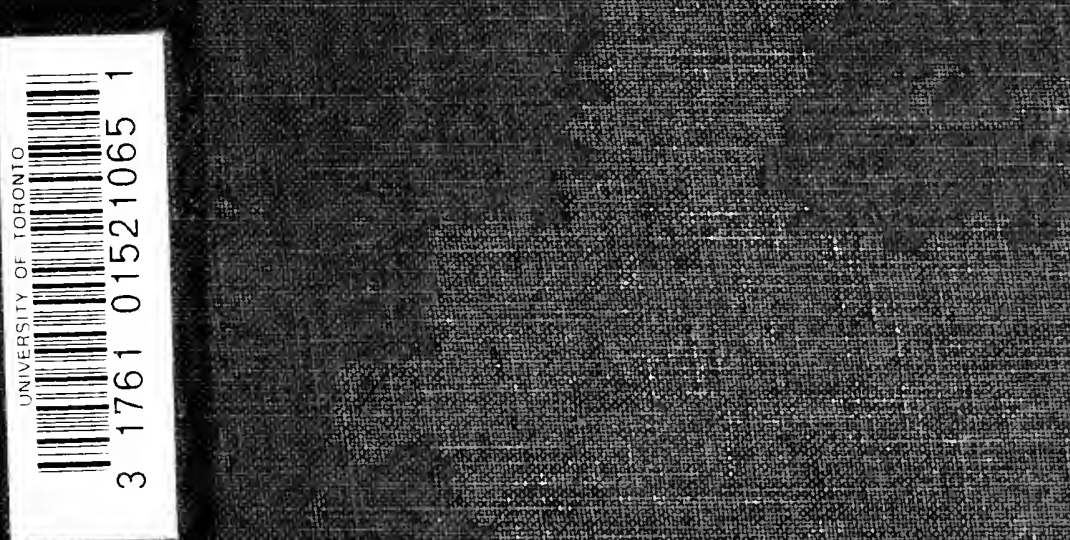

xis

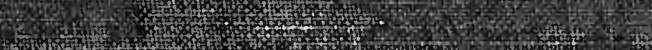
Now

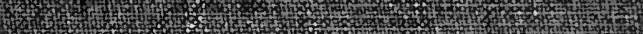

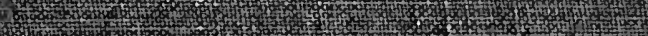
(5. A (1) A

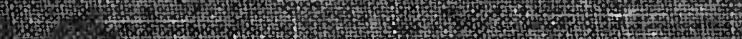
7. 20 Q

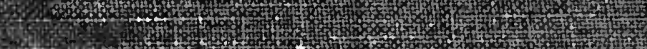
(1) 20 N 19.

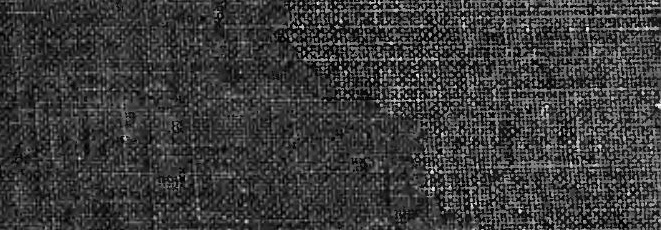

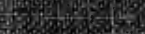
(1) (1) 896 S. 



\section{NIETZSCHE AND THE IDEALS OF MODERN GERMANY}

BY

\section{HERBERT LESLIE STEWART \\ M.A. (Oxon.), D.PH.}

PROFESSOR OF PHILOSOPHY IN DALHOUSIE UNIVERSITY, HALIFAX, NOVA SCOTIA FORMERLY JOHN LOCKE SCHOLAR IN MENTAL PHILOSOPHV, UNIVERSITV OF OXFORD LATE JUNIOR FELLOW IN MENTAL AND MORAL SCIENCE, ROVAL UNIVERSITY OF IRELAND AUTHOR OF "QUESTIONS OF THE DAY IN PHILOSOPHY AND I'SYCHOLOGY"

\section{LONDON}

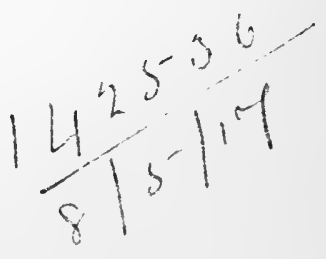

EDWARD ARNOLD

I9I 5

All rights reserved 


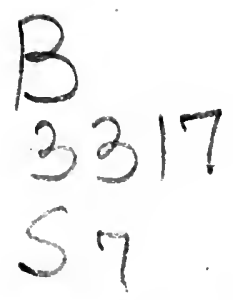

Digitized by the Internet Archive in 2006 with funding from

Microsoft Corporation 


\section{PIREFACE}

SiNce the war began Friedrich Nietzsche has been widely discussed, and the question has been asked how far his "Neue Moral" explains the attitude of the Germans in international affairs. Newspapers and magazines have been filled with estimates which may well bewilder the public. One critic declares that chapter and verse may be quoted from Zarathustra to justify every step which Germany has taken; another finds that no philosopher has spoken out more boldly against the spirit of racial aggressiveness-that, in short, Nietzsche is the champion of the German Geist, not as embodied in, but as contrasted with, the German Reich. In the heated language of the moment there is, of course, much exaggeration and much misunderstanding; unfortunately, the truth on the subject is somewhat difficult of access to the British reader. Most people are deterred from investigating at first hand when they find that some twenty volumes are to be consulted, and the available handbooks are unsatisfactory. Our competent teachers of ethics have, for the most part, passed Nietzsche by, and the work of expounding him has fallen largely to the zealots of his own school.

This series of lectures is the expansion of a short 
course which I delivered last winter to the students of Dalhousie University. They make no pretence to be an adequate appreciation of Nietzsche's place in the history of thought; I have confined myself to those aspects of his work which may cast light upon the social policy and ideals of Germany as these have been revealed in the present war. Much thatisvaluable in his teaching-for example, his suggestions towards a new theory of knowledge-it has been necessary to leave unnoticed. But to explain his ethical position I have had to include a fairly wide analysis of the anthropological and psychological basis upon which the whole has been made to rest. Hence this is neither a book on the war nor a book on Nietzsche's philosophy; it is an effort to assist those who wish to correlate the moral outlook of Germany with one personal influence by which, beyond doubt, it has been in part directed. And for those who believe that Nietzsche, properly understood, has been a force making towards cosmopolitan peace, I have set forth in detail the grounds upon which I believe the opposite.

We have lately had a revelation of character in German leaders by which not only we of the British Empire, who may well be prejudiced, but neutral nations which ought to be impartial, have been astonished and shocked. It is now needless to dwell upon the extent of that great exposure; I shall only say of it that the indignation of mankind has been roused less by what any outsider has said than by what the 
German representatives have said themselves-less by the reproaches of Germany's critics than by the candid avowals of her own statesmen. And not the least damning evidence has been supplied in those pamphlets by which her university professors have sought to conciliate neutral opinion. One manifesto after another has been issued by these eminent men, presenting the case for Germany with all the force which ingenuity can devise, and all the warmth which patriotism can inspire. These statements we have tried to read with whatever patience and whatever dispassionateness were under the circumstances possible. Two things are specially conspicuous in them-the disregard of facts which we think crucial, and the emphasizing of points which we think irrelevant. They are intended, of course, not for us, but for America; their authors begin with profuse courtesy about the fairness of the American mind, but after months of literary campaigning they are chagrined to discover that the Americans remain overwhelmingly on the side of the Allies.

The reason is not obscure. They have been conducting a " moral" argument in categories of good and evil which are entirely foreign to the conscience of their public. America wants an answer to some questions that are perfectly direct and perfectly unambiguous. She wants to know how the murder of the Archduke can have been the cause of a war which was contemplated a year before that murder took place; she wants to know with what purpose a 
strategic railway, of no commercial advantage, was built long ago right up to the Belgian frontier; she wants to know how this consorts with the claim that the assault on Belgium was a forced move at the last moment to anticipate a similar move by France; she wants above all to know why, when Russia and Austria were on the point of coming to terms, Germany-an outsider to the main quarrel-should have declared war. And America's reason for persisting in such inquiries is that she believes in the faith of treaties, in the rights of a small State, in the awful guilt of drawing the sword unprovoked. The German apologist evades her questions, or answers them in terms that are plainly false, or offers a multitude of answers that are mutually inconsistent. These are usual methods of a debater that is in the wrong; but an exceptional feature in the German defence is that it turns aside from such vital issues to propound a case clothed in moral phraseology but resting upon a thoroughly immoral postulate. The contrast between Teutonic culture and Russian or Slavonic barbarism is pressed incessantly upon the notice of Americans, and the implication is that this contrast should determine America's decision. When she wants to hear a plain unvarnished tale about justice and equal rights, but is offered instead a panegyric on the cultural eminence of one side as compared with the other: when she wants to know why a treaty was outraged, and is told that no treaty can be allowed to hinder the imperative strategy of war: when she wants 
to be shown why the Austro-Serbian difficulty was beyond diplomatic methods, and is told that Austria, with Germany's concurrence, had made up her mind to teach the Serbs a blood-stained lesson, and that after all the battle-field is not such a shocking thing as is commonly supposed-then America draws her own conclusion. She concludes that she is not hearing a defence within the terms of the morality which she reveres, but the avowal of a new morality manufactured to support a particular statecraft.

One key to the enigma of Germany is, undoubtedly, to be found in this sinister aberration of thought on ethical questions, especially on the issues of international conduct. There has been a current of such thinking in that country for the last thirty years, and by several noted litterateurs that current has been given expression. To the English observer it seemed too monstrous to be important, but we see to-day how far we were mistaken. We are forced to revert to it, if we would find the principles which make a systematic whole, clear in its shameful consistency, of the German programme from beginning to end.

In this book I have selected one representative of such thought for special study. That the prophet of Zarathustra " made the war" few persons will be foolish enough to believe. But that he enforced with singular effectiveness just those doctrines of immoralism which Prussia has put into execution, the following pages endeavour to show. No effort is made to hide those elements in Nietzsche's Evangel 
which tended another way; on the contrary, the reader will find these systematically set forth. But Nietzsche's points of agreement with militarism are, in my view, far more significant than his points of dissent. I take him, not as the originator of any policy, but as typical of a mood which has had fearful consequences for mankind; a study of his Weltanschauung may thus cast some incidental light upon the present tragic situation of Europe.

The references in the foot-notes throughout this book are to the authorized English translation of Nietzsche, edited by Dr. Oscar Levy. I have to thank two colleagues-Dr. A. MacMechan, Professor of English Literature, and Dr. H. P. Jones, Professor of Modern Languages-for much valuable help in the revision of proofs.

H. L. S.

DALHOUSIE UNIVERSITY,

HaLifax,

Nova Scotia, August, 1915. 


\section{CON'TEN'TS}

\section{LECTURE I}

THE RECOIL FROM PESSIMISM

Interest of Nietzsche's teaching-His life-His style-Dependence on Schopenhauer-Schopenhauer's conflict with Hegel-The world as will-Pessimism and the denial of "will to live,"-Nietzsche's criticism-Pessimism as a form of Nihilism, and both as products of decadence"Valuing" as "creating"-Decadent types in Zarathustra-The sources of Greek optimism-Birth of Tragedy-The "Apollonian" versus the "Dionysian" spirit-Nietzsche's affirmation of life as a whole

\section{LECTURE II ।}

THE "WILL TO POWER" AND "MORALITY AS DECADENCE"

Pessimism in the end a moral issue, hence to be solved by inquiry into origin of ideas "good" and "evil"Nietzsche's demand for an inductive method of ethicsAntithesis "good and bad" prior to "good and evil "Its origin traced philologically to the values of an aristocratic caste-All moral estimates rooted in will to powerBirth of asceticism in rivalry of noble and priest- "Evil " originated in plebeian resentment and the values of the herd-Social character of early morals-Source of ideas of obligation, conscience, guilt, punishment-Current values favourable to low racial type, and involving a denial of life-Criticism of Nietzsche's view-His inadequate equipment as an historian of morality-His anthropological and psychological blundering-Points of value in his account 


\section{LECTURE III}

\section{THE TRANSVALUATION OF VALUES}

Transition from will to power as psychological fact, to will to power as moral rule-Decadence a normal phenomenon of social old age-Need for a renewal of the values of youth, especially for a changed attitude towards sympathy and egoism - Nietzsche's attack on sympathy - The pitiful man defeats his own end, and favours the preservation of all that ought to perish-Was Nietzsche opposed to sympathy in its essence, or only in its less enlightened forms?-The hypothesis of "Eternal Return"-Reinstatement of egoism-A completely altruistic society impossible-Selfishness as the duty of those who are fit for it-Intrinsic value of great men-The "bestowing virtue "-Criticism of the Golden Rule-Assertion of a double morality, for masters and for slaves-Estimate of Nietzsche's revaluation-Prejudice created by his manner -Merits and defects in his treatment of sympathy and egoism-The problem, in the end, one of ethical axiomsNietzsche's inconsistency

- $58-90$

\section{$\checkmark$ LECTURe IV $\checkmark$}

\section{SUPERMAN}

Nietzsche and Darwin-The evolutionist formula of struggle -How Nietzsche applies this to eugenics-His view of womanhood-Nietzsche's dissent from Darwinism-His. insistence on purposive rather than natural selectionThe selective value of war-The Superman as goalLineaments of this ideal-Its possibility as the answer to Pessimism - Criticisms - Darwinism and ethics Nietzsche's eugenics-His inconsistency with his own earlier positions-Superman the negation of morality in any objective sense

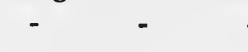




\section{ECT URE V}

\section{ARISTOCRACY}

Nietzsche's definition of an aristocrat-Contrast between the "objective" man of science or the "productive" man of art and the "creative" man of the higher order-Lineaments of aristocracy-A proud self-respect and self-confidence-Distinction between pride and vanity -The aristocrat as an instrument of progress-His truthfulness and his magnanimity-His instinct for rank -His isolation-The nobility of caste-Historical opposition of oligarch and democrat-The religious reinforcement of " herd values "-Elements of value in Nietzsche's analysis-Some virtues characteristic of high social strata, but these, in so far as they spring from caste feeling, hardly above the instinctive level-Limitations of democracy-Special circumstances in which oligarchy makes for progress-The exaggerations in Nietzsche's picture

$-$

$-$

$-$

- 118-148

\section{LECTURE VI}

\section{NIETZSCHE'S INFLUENCE UPON MODERN GERMANY}

Difficulties in such an estimate-The analogous cases of Treitschke and Bernhardi-Popular exaggeration of the influence of individuals-Nietzsche neither intimately known nor greatly cared about by general public, and much discounted by German philosophers-The view that he was an "individualist" and consequently against race-aggression-His attacks upon militarism, upon the régime of Bismarck, and upon the German hostility to culture-His cosmopolitan outlook-Do these features indicate that he was a pacific force?-His "individualism " worthless as a barrier against the Prussian spirit - His antithesis between culture and civilization-His cosmopolitanism based on the dominance of a casteNietzsche foresaw and welcomed an international Arma- 
geddon-He despised the "petty-State system"His indirect influence much stronger than his positive precepts-Justification of will to power meant an endorsement of Prussian policy in the past-Defence of military imperialism laid the basis for modern " exploiting rights of culture "-His emphasis on the value of war for war's sake-How these principles have been expressed in Prussian statecraft-Nietzsche both gave positive encouragement to selfishness and weakened every moral guarantee for the maintenance of peace

- 149-188

\section{LECTURE VII}

\section{NIETZSOHE AND CHRISTIANITY}

Nietzsche's religious training in youth-His subsequent attitude-Theory of religious origins in the psychology of primitive man-Influence of dreams and ecstasiesA deceitful priesthood-The "holy lie "-Weakness of Nietzsche's account-Special problem of ChristianityHis attack upon Strauss-Theory that the Christian morality was fundamental, and that dogma was but its intellectual reinforcement-Elements of truth in thisNietzsche's dislike of "half-measures"-His objections to Christianity as favouring pessimism, equality, and race decay-Can these charges be made out ?-Nietzsche's want of historical sympathy-His ignorance of modern interpretations of Christianity-His revival of the crudities of Deism-The present war as a crucial test of morale -Its relation to Christian principles-Is it a revelation of religious breakdown, or a conflict on a great scale between the Christian and the Nietzschean values?

- $189-232$ 


\section{NIETZSCHE AND THE IDEALS OF MODERN GERMANY}

\section{LECTURE I}

THE RECOIL FROM PESSIMISM

THE choice of Nietzsche as subject for a short course of Sunday afternoon lectures can be justified, I think, at present both on general and on special grounds. I speak under the auspices of an Association which exists to infuse Christian ideals of character into our University life. This is a fitting aim only for those who believe that these ideals are supremely valuable; if anyone has found elsewhere a worthier or a more fruitful stimulus, ours is an aim which he will not cherish, and may even oppose. Now, Friedrich Nietzsche is the writer who, above all others, has based his aversion to Christianity upon moral grounds. His was no mere scepticism regarding that view of God and the world which we call religious dogma; he looked upon this as already beyond the need of refutation, as a myth already exploded for wellinformed minds. But the axe, he tells us, has not yet been laid with real thoroughness to the very root of the tree. Amid all the negative criticism directed against theology, a tender regard has been paid to the Christian conception of virtue and obligation. Mankind has still to be taught that Christianity did 
not improve but rather corrupted to the very core the morale of Europe, that it has been the great counteractive of culture, that wherever it exists to-day-and just to that degree in which it is influential-low types of character flourish, contemptible qualities are encouraged, the higher impulses of man are strangled at the birth.

This challenge proceeds from a rare, though not a unique, point of view. As we examine, I trust in a perfectly impartial spirit, the grounds upon which it rests, we shall be forced to state to ourselves in an unusually explicit and discriminating way what we believe to be involved in the Christian ideal of life; when we set this in contrast with the principle which Nietzsche would substitute, we shall perhaps discover in it aspects and consequences which only such a process of contrasting can reveal.

But there is a special reason for the attention which has of late been fixed upon the work of this German thinker. The war which is desolating Europe may be looked at on many sides and interpreted in many ways; on one point, however, there is widespread agreement amongst all who consider it impartially. It has become clear that the opponents hold very different views about international obligation. The divergence is not simply one of practice; it is a divergence in the principles which are held with all honesty of mind by the contending parties. When one asks for the reason of this, one is met by a variety of answers; amongst them is the claim that certain historians, certain philosophers, certain journalists, have inoculated the German conscience with a moral perversion. Those who deal in picturesque 
exaggeration have tried to saddle the blame upon some individual writer. It is, of course, extravagant to suppose that one or two literary men have been so potent in turning the tide of an Empire's policy; yet one cannot help being impressed by the fact that the theories of life which a few German thinkers of high popularity have commended are very similar to those which German politicians and German generals have been translating into practice. Amongst these thinkers I am persuaded that Nietzsche has been one, although, for reasons to which I shall draw your attention, his part is specially difficult to define. When we have seen what his moral and social message amounted to, we shall try to estimate how far it contained the germ of the things which we have watched with horrified astonishment since last July.

Nietzsche's work is unlike almost anything else that has been known in the multiform course of ethical speculation. It is not the founding of a new school, offering a different interpretation of moral facts; by this time it would be difficult to originate such a school except as a fresh combination of old ones. Tennyson, you remember, writes in his poem, The Two Voices :

I know that age to age succeeds, Blowing a noise of tongues and deeds, A dust of systems and of creeds.

It seems scarcely possible that a complete novelty in the way of moral system should at this time of day arise, however violently the dust might be stirred. And yet that way of looking at the life of men and communities which we connect with the name of 
Nietzsche is not a revival of something propounded before. It has been called a renaissance of paganism, and that it is in essence pagan no one will deny. But neither can we deny that it is in its own fashion original. We shall put it best by saying that it is not, like other systems, an attempt to explain the phenomena of the moral consciousness of man; it is rather a titanic effort to transform that consciousness itself.

Nietzsche was born in the year 1844 at a village near Leipzig, in which his father was the Lutheran pastor. He showed very early a remarkable aptitude for classical learning, so much so that while still an undergraduate he was chosen to fill a Professorship of Classical Philology in the University of Bâle. This Chair he retained for only a few years, until his health broke down, owing to an affection of the eyes, which was afterwards traced to a brain lesion. After a period of sick-leave, which produced little improvement, he was pensioned by the University in 1879 . For a melancholy decade he passed from one health resort to another, working incessantly under the most adverse circumstances, publishing volume after volume in which he developed those ideas for which he has become famous. In 1889 came the tragic sequel; he was declared incurably deranged, and the next twelve years were passed in an asylum. The end came mercifully in 1900 .

An expounder of his views has certain serious difficulties to overcome. Nietzsche was no systembuilder-never attempted to articulate his thought into a harmonious whole, after the fashion which German philosophers above all other men affect. 
He aimed to be consistent, yet no man is a clearer, if an unconscious, illustration of Emerson's contempt for consistency, "that hobgoblin of little minds"; he chose just that epigrammatic and aphoristic style which makes consistency impossible. Fierce paradoxes abound, conflicting not only with common opinion, but with equally fierce paradoxes, which our author has fulminated elsewhere. It would, of course, be absurd to bind down a writer of this sort to anything like literal exactness: he is a stupid pedant indeed who would interpret the words of a poet as if they were legal formulæ. On the other hand, if we are to interpret Nietzsche at all, we must extract some definite teaching from what he has written; he took himself very seriously indeed, and has been very seriously taken by his countrymen; we could not dishonour his memory more than by looking upon him as a mere purveyor of bold, amusing cynicisms. But he has written in that manner which makes it most difficult to do justice to a man's opinions; one reader is charmed by the form and overestimates the content; another is provoked by the inevitable exaggerations, and cannot examine with patience the underlying thought. Nietzsche's German is brilliant indeed-perhaps, with the exception of that of Schopenhauer, the most striking German prose in existence; almost every page has its terse, arresting phrase; we are delighted by his virulent assaults upon convention; he has an intense hatred of cant, and where he is dealing with real cant he cuts wide and deep. If all the truth must be spoken, he appeals with force to that element in all of us which theologians have called the " natural 
man." But an author has not always written truly because he has written cleverly; there are few seductions more subtle than the seductions of style. On the other hand, such critics as von Hartmann, irritated beyond endurance by a philosopher who will not set forth his ideas in a system, have been, I think, less than fair to Nietzsche. ${ }^{1}$ At the least we must concede that he has given us a succession of striking and suggestive points of view, which we must assume and abandon in turn, but from each of which, while we keep to it, a very thought-provoking reconstruction of man and of society is disclosed.

We shall approach his central idea best if we think of him as brought up in the school of Schopenhauer; discipleship in that school was his first philosophic faith; reaction against it gave the impulse to his independent inquiry. Hence I have entitled this lecture The Recoil from Pessimism. We must begin with a brief statement of Schopenhauer's condemnation of life, and of the grounds on which that condemnation rested.

The influence of Hegel had become dominant in German speculation. Men everywhere had caught up the great idealistic creed, that the world is intelligible through and through, that Reality " contains no principle which can permanently resist the pressure of thought." The universe was described as Objective Reason, decipherable in every part, if reflection were sufficiently profound and sufficiently patient. Ultimate discord between mind and its material was a groundless fear; all things were in their essence spirit. Where philosophy had failed ${ }^{1}$ Cf. von Hartmann's Ethische Studien, pp. 35, 36. 
the error was one of application; inadequate or hasty thinking must be cured by thinking that was more thorough and more cautious. Thus, Hegel taught a boundless faith in intellect; he refused to recognize any limits to understanding such as those which, in Kant's view, understanding itself prescribes. And side by side with this confidence he inspired a fervent optimism, an assurance that the world of things would in the end be brought under the mastery of mind, that the great human values would be eternally vindicated when Reason without should have completely responded to reason within.

Schopenhauer, on grounds which I have not space to set forth, had challenged this whole scheme of interpretation. Its faith in reason was to him mere naïveté, its optimistic outlook a dishonesty of the intellect. Returning to Kant's doctrine of the Thingin-itself, he declared that thought is confined within the bounds of phenomena, that all argument from phenomena to their ultimate ground transgresses the limits within which argument must move, that the Reality behind all that we can see is impenetrable by reflection. The mind's incompetence was thus not accidental, but necessary and permanent. There was no such correspondence as Hegel had affirmed between the external order and the inward dialectic; one must rather conceive thought itself as an instrument of narrow range, the slave-as Hume put itof our passions and appetites. As such it was practically serviceable, but its limits were set by biological utility; it could read no speculative riddles; to think of Reality as " mirrored" in mind was mere assumption dictated by religious bias, a suborning of philoso- 
phy in defence of theism. What one could actually discern in nature was a process antithetical to design, a mere working of force, a struggle on the part of everything, good and bad, to maintain itself in existence. This was best put analogically as " blind, irrational will "; if any purpose could be assigned, it was merely that of the organism which resists dissolution, or of the matter which is indestructible; there was a ubiquitous " will to live," but there was no rational guidance of life, no specific goal to which things tend.

On such a basis Schopenhauer turned to face the problem of human values. Existence being such, is it for man really worth while? Does it justify itself as desirable? He replies that it is our nature to pursue the everlasting quest for what we cannot attain. Our suffering far exceeds our pleasure; pleasure itself is chiefly negative; it is the name we give to relief from discomfort. Intellectual advance brings only a greater refinement of discontent; we thus realize all the more clearly how deep is the gulf between aim and performance. It is the finest nature that feels disappointment most; but whether on a low or on an elevated plane, experience is at bottom identical, a round of baffled energy, unsatisfied desire, blasted hopes. Yet we never draw the moral by denying life; and in this circumstance one may see confirmation of the view that reason is the weakest force by which we are ruled; only such creatures as were goaded on by an irrational will to live could have survived the long process of disillusionment. We even argue that existence is "on the whole good"; but it is the blind cosmic impulse which prescribes to 
us this very falsification of thought, using as its tool that cajolery of the intellect which is called philosophic optimism.

What, then, is the remedy? Not the so-called "progress" of the Hegelian school, not the attempt to make reasoning more adequate or to rid experience of its failures. Inadequacy and failure belong to the very essence of will. Desire grows by what it feeds upon; if we seek to satisfy it we merely palliate, in the end we even intensify, the disease. One must, so far as possible, withdraw from the whole process; in æsthetic contemplation this is partially achieved, for we become disinterested spectators, not actors, in the drama. ${ }^{1}$ But to achieve complete redemption we. must starve desire, we must negate life, we must produce through ascetic discipline a spirit which no longer wills to live. The celibate should be esteemed a benefactor of his race, for he refuses to join in perpetuating a species doomed to pain. And, in general, all the virtues may be summed up under sympathya sense of pitifulness toward all who are, like ourselves, being broken upon the wheel, a feeling of oneness in pain with the whole sentient world. Neminem loede, immo omnes quantum potes iuva: the rational goal for humanity becomes something like the Nirwana of Buddhism, a paradise reached through extinction.

Schopenhauer was the idol of Nietzsche's early period, and we shall have to notice many points in which, strangely enough, the apostle of Superman has borrowed from the apostle of Nirwana. He

${ }^{1}$ Cf. The World as Will and Idea, i. 231: "We are then set free from the gross pressure of will, we keep the Sabbath of the will's hard labour, the wheel of Ixion stops." 
accepted fully all that his master had said about life's intrinsic pain; he repudiated with the same warmth Hegel's confidence in intellect; he thrust from him with scorn and even with hatred all suggestions of a guiding Providence, all notions of a future state in which the sufferers of the present should be " eternally indemnified." And yet Nietzsche recoiled from pessimism with all the intensity of a religious devotee. "World-contemners," "World-deniers," "Men faithless to earth, of whom the earth is weary-away with them !"- these became the expressions of his most bitter mood." "There was a time," he exclaims, "when the greatest sin was blasphemy against God; the greatest sin now is blasphemy against earth." How, then, having apparently admitted all that the pessimist affirms, and having scouted all the mitigations which either theistic or non-theistic philosophy has suggested, does he carve out for himself any way of escape? He does so in a manner that is truly original.

Pessimism, he points out, rests upon a certain assumption, taken for granted on one side and childishly conceded on the other, in complete ignorance that any prior question can be raised. The moment it is raised one can see that the thing presupposed is not only disputable, but outrageously false.

It is assumed that if the world can be proved to contain more pain than pleasure, and especially if it can be proved that this excess of suffering is permanent, life is eo ipso condemned. Hedonistic values are taken as decisive. What if it should turn out

${ }^{1}$ Cf. Zarathustra, i. 3, 4.

${ }^{2}$ Ibid., i. 3. 
that the scheme of things has some better purpose than to minister to my enjoyment and to assuage my inconveniences? What if it should be found that even for me there is some higher object than any that can be expressed in such terms of feeling ? 1 The worth of existence had been denied because it was examined in the light of certain categories whose validity no one dared to dispute. Suppose we can deprive these categories of their value $?^{2}$

To this point Nietzsche again and again recurs. What an ignoble conception one has of the universe if one looks upon it as bound to vindicate itself by the pleasure it gives to individuals! How grotesquely one exaggerates the importance of comfort! " People meet an invalid or an old man or a corpse-and immediately they say Life is refuted; but they only are refuted, and their eye which seeth only one side of existence." "I tell you there are higher problems than the pleasure-pain problem." And even from the point of view of man himself it is the weakest or shallowest of our species who see a goal in the elimination of suffering. " The discipline of suffering, of great suffering, know ye not that it is only this discipline that has produced all the elevations of humanity hitherto." 4 Thus, for Nietzsche, the great question comes to be this: Which of the valuing codes do you mean to adopt as highest? Suppose it should appear that the world is approved by the test of virtue though condemned by the test of pleasure? Suppose it should be neither virtuous nor pleasant and yet should be vindicated by the criterion of beauty? It

1 Will to Power, 35.

2 Ibid., 12.

${ }^{3}$ Zarathustra, i. 9 ; $c f$. i. 2.

4 Beyond Good and Evil, 225. 
is plain that we must begin by settling on some principle to which primacy belongs.

But, he goes on, the world-despising temper of our age has a deeper basis than even Schopenhauer was aware; pessimism is but one variety of that general attitude for which life, tried by every test, seems equally condemned. To this radical condemnation Nietzsche gives the name Nihilism. It is the assurance that "life is absurd in the light of the highest values yet discovered"; $;$ it is "disbelief in all values." "The most gruesome of all guests is at our door." Reason could no longer stay itself upon the objects of a transcendental world, upon God, upon Paradise, upon a redeeming plan; since it was just these which in the past had preserved life's confidence in itself, their dissolution had been followed by a complete failure of nerve. ' Purpose, Unity, Truththese were once guaranteed by theological metaphysic; they had fallen, and with them the values which they had supported. ${ }^{4}$ But the situation might yet be saved if we could only revalue the valuations themselves, if we could see other and better ideals of worth than any which the decayed dogmas had been invented to sustain.

Nietzsche was bred a philologist; and of one striking metaphor, drawn from his early studies, he makes frequent use. Such and such a picture of the world, he repeatedly exclaims, is " interpretation, not text." He means that so many marginal glosses have been inscribed on the book of nature that one can now

1 Will to Power, 3.

2 loc. cit.

3 Will to Power, 1.

4 Ibid., 12.

${ }^{5}$ Beyond Good and Evil, 22; cf. 38, 230. 
scarcely recover the original amid the mass of commentary. Not facts in their nakedness, but facts overlaid by criticism, above all by moral criticism, were offered to him who aimed at independent valuation. What were the so-called systems of thought but so many confessions of their originators, "a species of unconscious biography" ?1 ${ }^{1}$ One should always ask about a metaphysician: "What moral doctrine is he aiming at?" or "What sort of man was it who reflected thus?" If we examine Nihilism with this principle in our minds, do we not, he asks, become aware that the thing before us is far more a symptom than a problem $?^{2}$ A man does not think nihilistically because he has passed through a certain chain of reasoning; rather does this reasoning appeal to him in virtue of his being the sort of man he is. If an age is nihilistic it is because that age was first decadent.

Is not the question "To be or not to be?" a sign of sickness in him who raises it? Just as a morbid creature will keep examining his own arteries and feeling his own pulse, so it is anything rather than a virile, buoyant society which dwells upon "social problems," which substitutes the scrutiny of life for

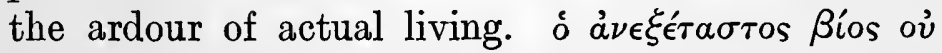
$\beta \iota \omega \tau o ̀ s ~ a ̉ \nu \theta \rho \omega \pi \omega$ : so said the Platonic Socrates, and, in Nietzsche's view, the man who said so certified himself a decadent. ${ }^{3}$ It was Socrates who initiated that period when energy became weak just in proportion as thought became minute. The Greeks had given us much, but we owed least to the philosophers among them, to the men who invented

1 Beyond Good and Evil, 6.

2 Will to Power, 38.

${ }^{3}$ Cf. Joyful Science, p. 34; Twilight of the Idols : "Socrates." 
systems of valuation, who taught us to sit in judgment upon nature, who interposed artificial barriers between man and the life that was his own-who, in a word, made us all ashamed of our instincts. Our debt was to the portrayers of Greek culture, to men like Thucydides-no sickly moralists, no nerveless calculators about right and wrong-men who have shown us how the greatest of all races lived when the world was young. Lowered vitality was not produced by the woes of existence which Schopenhauer had described. These were the effects, not the causes, of decadence. ${ }^{1}$ Vice, crime, alcoholism, hysteriathey were all present in every age; but they were made to bulk more largely, to assume terrifying aspects, because mankind had grown old, had lost the elastic spring of the past; we had received these things like microbes of disease into a frame of impaired vigour and lowered resistance. Mr. Schiller has put Nietzsche's point with great succinctness in the question: "What difference is made to the "facts" by our attitude towards them ?"

This decadence of modern Europe is embodied in figure after figure of Zarathustra, figures marked by world-weariness, by disbelief in values, by enfeeblement of will. Quietist philosophy is burlesqued in the professor who confided to his class that the summum bonum is really sleep, that the goodness of all good things and the evil of all evil things are to be measured by their effect upon calm, unbroken slumber. ${ }^{3}$ There is the vision of the "last of the Popes,"

${ }^{1}$ Will to Power, 42.

- ${ }^{2}$ In Quarterly Review, January, 1913, p. 153.

${ }^{3}$ Zarathustra: "The Academic Chairs of Virtue." 
the man " out of service," because the God he served has died; his old vocation is gone and he is unfit for any other. ${ }^{1}$ We have the minute scientific specialist who spends his strength over the dissection of a leech's brain-devotion, forsooth, to truth for its own sake-a devotion which any society with a purpose would have scorned, but which wins applause from degenerates in whom the spring of real life has snapped." The "voluntary beggar" turns his back, in blase revolt, upon civilization, seeks rather the company of the cud-chewing beasts, declaring that except ye be converted and become as kine, ye shall not enter into the kingdom of heaven. ${ }^{3}$ The climax is reached in the scornful picture of the "last man"; when the soil of humanity shall have become exhausted, when the arrow of longing shall no longer be launched, the world will be at a loss even to understand what strength of impulse once meant; the coming decadent will "love his neighbour and rub against him, for he needs warmth"; he will have the persistent vitality of the ground-fleas, and will be satisfied; "the last man liveth longest; we have discovered happiness; so saith the last man and blinketh."4

This seems to give us the key to Nietzsche's first book, The Birth of Tragedy. He thought of the Greeks as feeling from a very early time the problematic character of life, especially its disappointments, its sadness, its frustrated will. Silenus' reply to King Midas was almost an anticipation of the creed of

1 Zarathustra, iv. 66.

${ }^{2}$ Ibid., iv. 64. Cf. Beyond Good and Evil, 207.

${ }^{3}$ Ibid., iv. $68 . \quad{ }^{4}$ Zarathustra: Prologue, 5. 
Schopenhauer: "The happiest destiny, for ever beyond thy reach, is never to have been born; and the next best by far, is to return as swiftly as may be, to the bourne whence we came." Thus, if the Greek spirit was essentially joyous, a spirit that said "Yea" to existence, it was not because the poignancy of things had not been felt; theirs was a profound, not a superficial, optimism. How was it reached? Nietzsche indicated three ways.

There was first the creation of the bright and beauteous Olympian gods; they were a foil against everything sordid; even this world might be approved when thought of as their workmanship, under their governance, embodying their purposes. Man might in thought detach himself from the welter of struggle, might place himself at the point of view of the divine artists, and while he could feel himself a sort of disinterested spectator, he might share the joy of the gods themselves. "Only as an æsthetic phenomenon can the world be justified." This attitude Nietzsche called the Apollonian spirit; its products were especially those of painting, sculpture, epic poetry. Homer, Pheidias, Polygnotus-such as these were the first opponents of Greek pessimism.

Later than this came the method of rationalistic discussion, the method of him who would rise to the height of a great argument, that he might "justify the ways of God to men." Science, philosophy, the arraignment of everything before the bar of reason; the search for canons and principles-this was the movement best called Socratic, a movement which had never since been allowed to pause, and to which, 
just because the world cannot be logically vindicated, a great deal of European Nihilism was due. But intermediate between the spirit of Apollo and the spirit of Socrates we could discern the spirit of Dionysus, and its deathless expression had been found in tragic drama. Aristotle was entirely wrong when he looked for the motive of tragedy in a $\kappa a ́ \theta a \rho \sigma \iota s$ of the emotions; this was but a moralist's misunderstanding: Greek drama had its root in an age far too robust for morality. In the mythic struggle between Zeus and the Titans one ought to see a symbol of the war between nature and restraint, between instinct and conventional order. Dionysus with his satyrs was the type of passion that refused a bridle, of a will that would not mask its impulses under the thin veneer of law. The satyr-play was the germ from which tragic art arose; and the thing which drew highly civilized Athenians to witness this sort of orgiastic revel was the chance of returning again in thought to the elemental forces of life, of looking at it unexpurgated, unrefined, undisguised, with its intoxications not less than its sanities, its ruthlessness equally with its controls. The moral that it brought home to him was one that could not be articulated by logic, but could be felt with an ardour beyond anything that logic ever knew; it was the thought of the eternity of will, of the world-forces as sweeping on though the individual may be engulfed; it was the reckless affirmation of life, not in spite of, but even because of its fulness of passion, of suffering, even of cruelty. Hence there was no "poetic justice" in the great tragedies; an Edipus or a Prometheus does not end in an exhibition of the good man's final triumph 
or the motto that virtue is its own reward; Aschylus and Sophocles were no artists of Esopic fable. And if we could not to-day enter into the Dionysian spirit, it was because we had been taught artificial valuations, because we had been brought up in a school half decadent with moralizing, half besotted with philosophizing.

We are not concerned with the philological merits or demerits of all this; as a contribution to our knowledge of Greek culture it has received scanty respect from those best competent to judge. A piece of literary history written in such disregard of historical evidence, and relying so much upon the author's a priori insight, could not find favour with scholars. One cannot wonder at the severe handling of Nietzsche by so eminent a Grecian as Willamowitz-Moellendorf, or at the pained disappointment of his own friend Ritschl. But the spiritual attitude taken up in the Birth of Tragedy was maintained by Nietzsche to the last. He reverts to the subject in his Twitight of the Idols, summarizing it thus:

"The affirmation of life carried even into its most formidable problems, the Will to Live exulting in the knowledge of its inexhaustible fecundity, in the presence of the destruction of the finest types of humanity, that is what I call the Dionysian spirit; and it is there that I found the key to the soul of the tragic poet. The tragic soul does not wish to get rid of pity and terror, it does not wish to purify itself from a dangerous passion by means of a violent explosion of this passion-which was what Aristotle understood by it--no; it wishes, far above pity and terror, to be itself the eternal joy of the future, the joy which also understands the joy of annihilating."

1 Twilight of the Idols : "What I owe to the Ancients." 
This tragic attitude was the thing which Nietzsche wished to reinstate as the Weltanschauung of Europe. But he has no hope that the prevailing morbid outlook will be quickly dispelled. His account of Nihilism begins with the remark, "What I am going to relate is the history of the next two centuries." The omens, he held, were clear; Europe must be nihilistic for generations to come. Nor did he wholly deplore this, for decadence was an inevitable stage in the life of a society; it must grow old and decay; it must have its autumn and winter if it is to reach its spring. Socialism, full of schemes for improving the world, for charming the pain out of it, was mere naïveté it was one long administration of anæsthetics to dull the symptoms of disease. Decadence had no radical cure; indeed, men must get worse before they could get better; the essential point was to prevent the decayed elements from infecting the elements that remained healthy. Perhaps a colossal war would be the best instrument for surgical cure, a suggestion to which we shall have to return as we trace Nietzsche's influence upon current events.

One is disposed at first sight to underrate the importance of this view. We may sympathize with the judgment that pessimism and Nihilism are morbid products; we may agree that they are signs of decadence. But we feel that something more must be said. One may discount the illnesses of a hypochondriac; but one does so because his symptoms can be shown to be subjective. Must we not similarly take note of what a "world-despiser" has got to say? Must we not satisfy ourselves that the values which he thinks lost are really preserved, or that the things he 
values are not really the most important? So far as we have yet followed him, Nietzsche appears to substitute dogmatic assertion for reasoned inquiry; his wholesale acceptance of life as it stands, his refusal to admit that anything in it is other than as it should be, his attitude of "saying yea" to the whole panorama of crime and suffering and disorder, ${ }^{1}$ all strike us as senseless paradox. But such a decision would be hasty. We have yet to see the grounds on which he declines just that standpoint of valuation which the modern man adopts; we have to grasp the argument in which he assigns to this an origin such as will rob it of its validity; and we have to consider in what respect he found in man the promise of higher things if his age of stupor could be made to pass.

${ }^{1}$ Cf. Will to Power, 881: "We recognize ... that with every growth of man his other side must grow as well; that the highest man, if such a concept be allowed, would be that man who would represent the antagonistic character of existence most strikingly, and would be its glory and its only justification." 


\title{
LECTURE II
}

\author{
THE “WILL TO POWER,” AND “ MORALITY AS \\ DECADENCE"
}

Nietzsche's reply to pessimism was, as we have seen, a direct negative; his denial was aimed, not against the pessimist's facts, but against the pessimist's valua- $v$ tions. He refused point-blank to see any serious evil in those features of life upon which Schopenhauer had rested his gloomy argument. This raises the problem, "How is it possible for men to value thus differently in such a sphere?" There is, of course, an arbitrariness in matters of taste, but it is, above all, in the light of moral values that the world's worth has been doubted; is there legitimate difference of moral standard among different critics of life? Is it a question of individual temperament, or is one view true and another false? Is there an objective rule which all should apply? The solution must come from a radical inquiry into the source and justification of moral valuing.

For the sake of clearness, I shall divide this lecture into parts. We shall first trace, following so far as possible Nietzsche's own language, the way in which he conceived the ideas "good" and " evil " as having historically arisen. Then we shall see how he accounts for that other moral standpoint which employs the idea of obligation rather than the idea of value, 
which rests upon the Kantian " ought" rather than upon the Aristotelian "good "; it will be found that this way of thinking, though distinct from the method of valuation, arose naturally from that method, and we shall examine what Nietzsche means by depicting it as a source of racial decadence. In the third section I shall attempt to estimate how far our author's genetic account of morality will bear criticism.

I.

Nietzsche claims that ethical inquiry ought to have been inductive, but that - to the shame of moralists be it said-induction in this sphere was almost unknown. The first step should have been a "comprehensive survey and classification of an immense domain of delicate sentiments of worth and distinctions of worth, which live, grow, propagate, and perish "; ${ }^{1}$ but philosophers had disdained this wholesome drudgery, they had preferred the " high priori road " which, in this case, could lead only to a begging of the question. "They wanted to give a basis to morality -and every philosopher hitherto has believed that he has given it a basis:" "How far from their awkward pride was the seemingly insignificant problem-left in dust and decay-of a description of the forms of morality, notwithstanding that the finest hands and senses could hardly be fine enough for it !"2

It is characteristic of Nietzsche that he ascribes this waywardness of method to wilful dishonesty. Academic teachers were in the pay of the State; they

1 Beyond Good and Evil, 186.

2 loc. cit. 
pretended to settle a question which they dared not even raise; they had taken a bribe to buttress up the existing order, or they were so filled with Christian fanaticism that they would falsify science to preserve dogma. ${ }^{1}$ In any case, they discussed their subject within the limits of an assumption; current approvals and disapprovals were taken for granted. Instead of guiding the world as to the truth or falsity of its ideas, these were accepted at their face value; philosophers had confined themselves to the ignoble task of putting in order an edifice which others had built. English writers had not sinned quite so deeply as the rest; they had at least faced the genetic problem; but their blind confidence in Association Psychology had misled them into seeking the springs of valuation just where these could not be found-in a fortuitous mechanism, in the vis inertice of habit and forgetfulness. ${ }^{2}$

Nietzsche's own basal proposition on the matter is this: (A moral value is not something which we find and which we must necessarily accept; it is something which we create, and which to the best of our power we induce or compel others to acknowledge.) Philologically, he says, the antithesis "good and bad" has quite a different origin from the antithesis " good and evil." The former was primary; if one examined the word for "good" in the chief European languages, one found that it denoted at first the qualities of a noble as contrasted with the qualities of a plebeian. ${ }^{3}$ It took its rise in the epoch of warrior chiefs; consider the Latin bonus derived from an earlier duonus, like

1 Cf. Joyful Science, p. 345; Rosy Dawn, Preface, sect. 3.

${ }^{2}$ Genealogy of Morals, i. 1.

${ }^{3}$ Ibid., i. 4. Cf. Beyond Good and Evil, 260. 
bellum from an earlier duellum ; ${ }^{1}$ or take the Greek

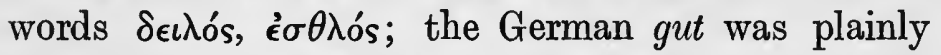
synonymous with godlike, pointing back to the upper order among the Goths; it was only as late as the Thirty Years' War that schlecht lost its first sense of "groundling" and became specialized in a moral direction. Everywhere the aristocratic caste was found applying to its own characteristics the epithet good; everywhere this originally meant a distinction of rank. Nor was it difficult to see how the transition in meaning had been effected; one might compare the ambiguity in the word "noble." For the ruling order was marked especially by high courage, truthfulness, a pride that scorned disguise or deceit, a spirit too contemptuous to be revengeful. In short, there was for Nietzsche no moral affirmation so profound or so original as Noblesse oblige. But the obligation which the aristocrat acknowledged was solely to his own nature and to his equals in whom he saw that same nature exemplified. To the common herd he had no duties; they existed as material for his " exploitation "; he had no bad conscience for any treatment, however harsh, to which he might subject them; they were beasts of burden, he was the "blonde beast of prey." Hence the exultation, unmixed with any tinge of remorse, with which the old Teutonic conquerors would return from a carnival of rapine and lust. Even after some thought for the mob had begun to affect a chieftain's mind, it was marked by scorn not less than by sympathy; “" ' Bad,, ' low,' never ceased to ring in the Greek ear with a tone in which "unhappy' is the predominant note;" "Let philolo-

1 Genealogy of Morals, i. 5. 


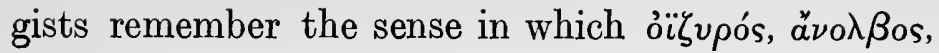
$\tau \lambda \eta \dot{\eta} \mu \nu, \delta v \sigma \tau v \chi \epsilon \hat{\imath} \nu, \xi \nu \mu \phi o \rho a ́$, used to be employed."1

Linguists, I understand, have not thought Nietzsche's etymologizing on this matter worthy of any great attention; but we must remember that he himself did not rest his ethical position upon any precarious theory about the original meaning of words. This was but the clue which suggested to him the track along which the basis of moral differences might be reached; the guarantee that he was right came, like so many other things to Nietzsche, by a flash of intuition. It was to him beyond question that every man values or tends to value as good the qualities which he himself possesses; as the most influential people were at first warrior chiefs, and as these were at the same time the only persons who were at all reflective, the aristocratic values were primary among mankind. This is what is meant by the statement, "The concept good did not originate among those to whom goodness was shown, but among those by whom it was shown." 2

Why does man thus value the qualities which he has? Nietzsche's answer may be compared with Herbert Spencer's explanation of the identity between acts that are pleasurable and acts that promote life. Only such creatures as found pleasure in wholesome sorts of conduct could survive in the evolution struggle; this was a corollary from the view that the end of every organism is life. For Nietzsche the end of every organism is not life but power in consequence, wo (must strive to win influence for the special type to which we ourselves belong.) Thus, a sort of

${ }^{1}$ Genealogy of Morals, i. 10.

${ }^{2}$ Ibid., i. 2. 
esprit de corps is at the root of all moral valuing. As one man's health may be another man's sickness, so the code of one society cannot be the code of another. ${ }^{1}$ Every man must devise his own virtue. ${ }^{2}$ In so far as proof can be given of this it must come from the success with which we can in the light of such a principle explain the moral estimates that have been historically formed. We must " suppose that nothing else is 'given' as real but our world of desires and passions "; $;$ can we show how certain of these have won such influence over the rest as to have become hardened into a system which pretends to be objective, lays claim not only to the allegiance of those who created and used it, but even to the submission of those against whom it works? Assuming that the (sole motive is will to power) can we unmask the various moralities, and exhibit this will lurking under each of them? Nietzsche asserts that we can.

He points out that every such valuation must "work backwards";4 that is, we attribute moral worth to the qualities which have in the past enabled us to win our way against our rivals. (All schemes of ethics are " efforts to codify the expedients found useful by some given race in the course of its successful efforts to remain alive.") First among such codes is that of the ruling nobility; its virtues are those of a dominant order. But over against the influence of chiefs there soon arose the rival influence of a priesthood. A class with no healthy fitness for leadership set up claims of the ghostly kind, exploited

1 Joyful Wisdom, p. 120.

${ }^{3}$ Beyond Good and Evil, 36.

s Mr. H. L. Mencken.
2 Antichrist.

4 Will to Power, 110. 
its very physical weakness as conducive to inspiration, coined the contrast "clean and unclean," affected to be the channel through which deities acted upon mankind -in a word, created an apparatus of spiritual dominion. The fears of the vulgar were easily wrought upon; what was the agelong conflict of Church and State but a struggle for personal ascendancy between king and priest? Out of this struggle had grown two moral systems, for each side was supported by special human types, and each in turn cast its sanction around the character by which it was best served. Abundant vitality, free scope for the manly impulses, courage, truthfulness, honour, glad submission to one's natural leaders-these were the virtues fostered by the secular aristocrat; it was on the reverse of these that the priest had to ground his authority; he secured himself by disparaging things physical, he declared war on the instincts, he depreciated courage to exalt holiness; the atmosphere in which such as he could rule must be an atmosphere of lies-a mythical world of the "soul "-and in consequence ecclesiastical man had come to cherish a code which was fatal to honour, fatal to patriotism, favourable to cunning and deceit-in short, the apotheosis of the reptile in human character.

But priest and noble were alike aristocrats-lords spiritual and lords temporal; the values of "herdmorality" had yet to be called to life. This was effected when a certain suggestion was broached, and ran riot like wild-fire through an inflammable material; it was proposed that the good of the average man, of the greatest number, of the " public" as contrasted with high or exceptional natures, should be enthroned 
in the highest place. War was declared against the supremacy of any individual or any small group; men were proclaimed to count alike. Thus, the values which began to rank first were those to which average impulse pointed, no high dominance like that of the noble, no severe asceticism like that of the priest, but dull commonplace comfort, an equally distributed happiness, that feminine shrinking from the strenuous, competitive, painful life which reached its climax in the maudlin eighteenth century. Such an ideal was clutched at by those who had most to gain from it; Dr. Levy puts Nietzsche's point with precision when he writes: "Who swore that it was incumbent on men to love their neighbour as themselves, to break their bread with the hungry, to give them their cloak and their possessions? They who had nor bread, nor cloaks, nor possessions, they who might win by the bargain." ${ }^{\prime}$ Clearly this, conceived as a bid for power, would emanate from that class to which most power ultimately belonged, to the men strong with the strength of overwhelming numbers. It was these who were able to make their own values influential beyond all values that had preceded; it was their strategy to say of the wealth which the world had to offer, "Let it be neither mine nor thine, but let us divide it." Hence charity, mercy, benevolence, justice, equality; hence all the moral estimates that have become supreme in modern Europe. Hence the bitter disapproval of all that would exalt one without exalting another; for " the more dangerous a quality is to the herd, the more completely it is condemned."2

${ }^{1}$ Oscar Levy, The Revival of Aristocracy, p. 38. Cf. Beyond Good and Evil, 260.

2. Will to Power, 276. 
Thus arose, in Nietzsche's view, the specific concept "(evil)" as distinguished from "bad." Its source was in the feeling of resentment and the impulse of revenge) it made vocal the " hatred of the mediocre against exceptional natures." ${ }_{1}$ The aristocrat lived in confidence and openness with himself; he took his happiness as a matter of course; it came from the abounding vitality that pulsated throughout his being. The plebeian could not fail to see this, but he might close his eyes to it; he became envious, he sought compensation by "lying himself into happiness," by drilling his mind to conceive of physical and intellectual distinction as saturated with "evil," by inventing the cult of the common. "The revolt of the slaves in morals begins in the very principle of resentment becoming creative and giving birth to values." This upheaval, though distinct from the change initiated by priests, found much support in the creed which priests for their own end had propapated. In the struggle between the two types of aristocrat one side had strengthened itself through disloyalty to the aristocratic principle, very much as one despot may invoke mob feeling to help him against another. ${ }^{4}$ The herd was thus provided with leaders, and these, Church aristocrats though they were, must encourage a spirit of equality; ghostly dominion rested on the principle that all men are alike, that-in Nietzsche's exquisite phrase-“" the fools, the bungled and the botched" are of the same intrinsic importance as the noble and the well-constituted. Only thus might they all alike be made amenable to the
1 Will to Power, 283.
${ }^{2}$ Genealogy of Morals, 10.
3 loc. cit.
${ }^{4}$ Ibid., 7. 
penal courts of the Church. But when the divine sanction decayed, as in revolutionary France, did the moral system decay with it? Not at all; the old imposing credentials were revealed as a forgery, the claim was exposed in the light of its genuine origin. But a new and a stronger power was now active. "An authority speaks. ... Who speaks? ... God speaks. ... Now, admitting that faith in God is dead, the question arises once more, 'Who speaks?' My answer, which I take from biology and not from metaphysics, is, "The gregarious instinct speaks. That is what desires to be master; hence its 'Thou shalt." " 1

These values, those of the noble, the ecclesiastic, and the herd, are depicted as the moral stuff out of which European ideals have been fashioned; in accordance with the ups and downs of such ways of feeling, in proportion as they have by turns become predominant, we must interpret the course of civilization. Under many forms it was a single principle that had ruled-the principle of will to power; the significant question about every stage was, "Whose will to power ?"2 You might look at it by periods-the mediæval epoch as the supremacy of priests, the sixteenth century as the supremacy of aristocrats, the eighteenth as the supremacy of the herd; you might trace the sinister league between Churchman and demagogue in the paradoxical but very genuine reinforcement of Christianity at the hands of the French Revolutionists. It was a small matter that they erased the name of God from State formulæ and from school curriculum; they perpetuated the values which lie at the basis of religion;

1 Will to Power, 275.

2 Ibid., 274. 
through them the reign of Christianity was " protracted." Nietzsche, who was, above all, a master of words, leaves us in no doubt of what he means; his commonest term for the motive behind all values is the term that is best translated "exploitation." Every class, in all that it did, and very especially in the estimates which it rendered influential, and through which it worked, had the single aim, conscious or unconscious, of "exploiting" the remainder. ${ }^{2}$

This is Nietzsche's account of the source of moral valuing as given in one of his late books, Beyond Good and Evil. It may be worth while to look at one of his earlier works, Human, All-Too-Human, in which he explains the same phenomena as arising by necessity from the needs of the primitive tribe; there is no contradiction between the two views, but the standpoint is somewhat different.

He points out that every man, belonging as he does to a specific class, thinks as his class thinks, long before he can regard life in an individual or independent fashion. One's outlook is at first that of one's clan or nation; to vary from or oppose this belongs to a late period of development. Now, as certain ways of acting are useful, and certain other ways are injurious to the community, the individual member must be taught to value the former and condemn the latter. "Good" and "bad" were nothing more than names by which the distinction in tribal utility was symbolized. But the origin of the contrast was soon forgotten, though the contrasting

1 Will to Power, 94, 95.

${ }^{2}$ Cf. especially Beyond Good and Evil, 259. 
words continued to be used. Hence a new meaning had to be found for them; they were taken to stand for some intrinsic quality in actions apart from any results, useful or otherwise, to which these actions might lead. Thus, men still said that good is good and bad is bad, no matter what the external outcome may be. The next step was to attribute these qualities, not to conduct, but to the motive from which conduct springs; as Kant put it, the only thing unconditionally good became the good will. Then we ceased to consider motives in isolation; we dealt with a "character" which displays itself in the kind of motives by which a man is habitually influenced; and it was felt necessary in order to stimulate effort that one should think of himself-however illusively -as able to control his impulses, able to mould his character; he was represented as " responsible first for his conduct, next for his motives, and, finally, for his very nature."

Thus, the (idea of goodness arose from what the tribe thought, or rather found by trial, to be of utility to itself. But even good things are useful in varying degrees, and different things are useful to different tribes. Hence the hierarchy of values, the ascending scale in which a community groups qualities in their order of merit; hence, too, the fact, otherwise inexplicable, that one nation esteems what another despises. For example, among a particular race and at a particular stage justice was socially valuable; for another race and at another stage revenge may be the first of " moral duties." And, finally, within a "single people arose a distinction of classes, especially the distinction between rulers and ruled. The 
national consciousness in a large society was easily lost; working men came to think as working men, employers to think as employers. Thus, a man began to value as "good" the qualities which were useful to his own subdivision, and to condemn as bad the qualities of the competing set; there were the virtues of the herd and the virtues of the master. We must abandon the idea of a moral reason with its cold, clear light; all depends on which side of the social fence we are behind.

\section{II.}

Returning to the three kinds of feeling, aristocratic, ecclesiastical, and gregarious, we must note that while Nietzsche often applies the epithet " moral " to each of them, he elsewhere restricts it to the third. Thus, in his denunciations of " morality" he has in mind the accepted code-that blend of democracy and priestcraft-which is current under the popular institutions of Western Europe; we shall see later in what way and with what success he defends a code of his own, a "Neue Moral." It is of the essence of his thought that the accepted valuations have no ultimate, unchangeable nature; they are derivative, explicable in terms of an earlier feeling which had not yet been moralized, which might have received some other development, but which, as a matter of history, has received this development. Hence he accuses all or nearly all the thinkers who preceded himself of accepting as " the given" what was really the given plus a particular and a very disputable 
manipulation. This is tersely brought out in his statement, "There are no moral phenomena, only a moral interpretation of phenomena; the origin of this interpretation lies beyond the pale of morality."1 He separates himself toto coelo from those expounders of ethic who begin by saying that their doctrine is related to " moral facts" in the same way in which botany is related to the life of the plant. For the botanist's facts, he would argue, are genuine; the philosopher's have been so far fraudulent, manufactured; the theoretical need of the age is to get back to that which is the real datum-namely, will to power.

Among these manufactured products he found certain concepts, enormously influential, hence of the utmost service for the ends of a power-seeker. What were these? Such ideas as obligation, responsibility, conscience, guilt, merit, punishment. Who were the artificers of this spiritual machinery? Whence, for example, the notion of " ought" ?

Assuming that man was at first frankly animal, that he had not yet begun to delude himself with myths about a "soul," it is pointed out that his impulses and passions must have been free, buoyant, selfassertive. Some individuals of the species would, of course, be stronger, more masterful than the rest; in an age of war these would be the "blonde beasts of prey," they would subdue the weaker beasts to their will. Thus arose the State; our author scouts Rousseau's absurd idea of a social contract: " $\mathrm{He}$ who can command, he who is a master by nature, he who comes on the scene forceful in deed and gesture, 
what has he to do with contracts?" Thus, forced into subjection, the lower class were kept so by having instilled into them the thought that they owe certain things to the heads of their community. The debt was, of course, fictitious; the primitive subject had been placed where he was simply by the superior strength of another. But the notion must be spread abroad as the basis of enduring power. As yet there was no thought of responsibility in the sense of freewill to act in this way or in that. Such distinctions as " intentional," " negligent," " accidental," were the fruits of a civilization relatively advanced; only by a ludicrous anachronism had they been ascribed to man in his early stages. Thus, when the subject had been taught to look upon the State as his creditor, it was natural to accept the consequence that the creditor would insist on payment, and would be relentless towards default. Punishment was simply retaliation, and at the earliest period-as all anthropologists knew-it had no vital connexion with the evil-doer's responsibility; his innocent kindred must suffer with him; it was a case of anger which "vents itself mechanically on the author of the injury." Thus, out of the material "owe" there grew the moral "ought"; and as a natural inference, every misdeed was thought of as having its equivalent price: witness the custom of handing over a kinsman to give his life to the tribe for a life that had been taken; witness, also, the compositio of the Teutonic peoples with a sliding scale of Wergild. The whole

${ }^{1}$ Genealogy of Morals, ii. 17. This essay is the source for the following abstract: it is needless to give references for all the points in detail. 
was rooted in the " primary forms of purchase, sale, barter, and trade."

But there was no limit to the shape in which such compensation might be tendered. As contractual relations developed, men would offer as security against default all manner of pledges; one might stake his life, his wife, his freedom, his body, later on his salvation, his soul's welfare, his peace in the grave. Especially common was the type of bond required by Shylock; the creditor claimed the right to inflict pain or mutilation on the debtor's body. The idea was that an equivalent might be rendered, not in some material fine, but in giving a sense of satisfaction to him whom you had injured. The extent to which this went on confirmed what psychologists knew on other grounds-namely, the joy in cruelty which belongs to man's nature; in the penal retribution of public law this tendency of individuals had reappeared on a greater scale. To inflict suffering "constituted the great delight of ancient man "; one could see it in the feasts he made for his gods and the tortures he carried out for their amusement. "It is said that the apes in inventing bizarre cruelties are giving abundant proof of their future humanity, to which, as it were, they are playing the prelude."

Turning next to the notion of responsibility, Nietzsche finds that this also has been a result of State pressure upon the individual. Communal need prescribed that each member of the tribe should in his actions be calculable. This was at first secured by the reign of custom: a cast-iron system of conduct was handed down from age to age; every tribesman 
behaved exactly like his fellow through blind tradition and imitativeness. But a more reflective mood produced independence, hence the need for explicit guarantees; Nietzsche puts this in his characteristic fashion when he refers to Nature's task of " breeding an animal which can make promises." But how ensure that the promises shall be kept? Man must be made to feel " responsibility," and this involves the attaching of pain to a neglected engagement. From the standpoint of modern science, free-will was of course absurd; but it was one of those valuable lies which, in its own interest, a Government must disseminate; it served the cause of discipline, without it the transition could never have been made from animal to man. And it was the lesson of "the longest and oldest psychology in the world" that " only that which never stops hurting remains in the memory." Thus was formed a sinister but very effective system of mnemonics.

The individual must be kept with a constant burden on his mind that he is in debt to outside authorities, and his character must be so trained that he shall have no rest till the creditor's claim has been discharged. Hence the social utility of "pangs of conscience." The wretched man's liabilities were toward many claimants; there was the State to which he owed obedience, allegiance, service; there were his ancestors from whom he had derived life itself, and to whom return must be made in sacrifice, in festival, in temples of veneration-above all, in sedulous observance of the traditions they had laid down. By degrees, in the crude logic of that period, an ancestor assumed monstrous and even divine prestige; he 
became transformed into a god.1 How shall his claims, then, be sufficiently met? "Owing something to God! This thought becomes his instrument of torture."' It was seen to an extreme degree in that Christian doctrine of man's inability ever to yield a perfect satisfaction to the Divine creditor, in the thought of permanent bankruptcy at the bar of Heaven. ${ }^{3}$ Thus arose the notion of guilt, in its origin of sheer social expediency, to ensure that a man's action might be predictable. Finally, there was the idea of punishment, and of desert. Nietzsche warns us against the common assumption that punishment was at first deliberately devised to serve the purpose for which it has since been used. ${ }^{4}$ He distinguishes a permanent element and a fuid element. To begin with, it was spontaneous retaliation, the lex talionis, an eye for an eye and a tooth for a tooth; it was rooted like responsibility in primitive barter. Only the stupid genealogists of law could introduce the later utilizations of punishment into the original procedure itself. These latter had been very variousto incapacitate the criminal for further injury, to frighten others, to purge weak or insubordinate elements out of the State, to maintain social order. ${ }^{5}$ Such ideas were fluid, variable, dependent on particular grades of civilization; the feature that was permanent and ubiquitous was the appeasing of an impulse of cruelty, the giving vent to a desire for another's suffering. Did not Tertullian and Thomas Aquinas conceive the righteous retribution of the

1 Genealogy of Morals, ii. 19.
${ }^{2}$ Ibid., ii. 22 .
3 loc. cit.
4 Ibid., ii. 13.
${ }^{5}$ loc. cit. 
wicked as one of the luxurious spectacles which should go to make up the bliss of Paradise ? ${ }^{\mathrm{I}}$

The world being thus in its essence will to power, and each class having equipped itself for the contest, Nietzsche faces the problem, "Which forces are winning?" "Whose will to power is getting its way?" He answers that the most ignoble types are uppermost, the higher types are being suppressed. All other values have been thrust back that the values called " moral" may be installed. " No greater power did Zarathustra find on earth than good and bad ;"2 (such aims as strength, beauty, racial fitness)-all, in a word, that (belong to a select class and cannot be universalized have been displaced in public esteem, and the means that were effective towards these have been abjured; the "moral idiosyncratist" has been allowed to shape the human type, and he has shaped it straight towards decadence.

The signs were obvious-herd morality was everywhere preached, the cult of the mediocre, the denial of special right to exceptional men, the equalizing of all, high and low. Was it any wonder that even lofty spirits like Schopenhauer had become Verüchter des Lebens (despisers of life)? The tragedy lay in this, that Schopenhauer did not see how life had become despicable just because of that standpoint from which he and others like him had chosen to regard it. They had caught the democratic contagion, but, unlike the democrats, they were noble enough to be disgusted with the meanness, and discerning enough to see through the futility, of democratic ideals. Hence they called existence vain, devoid of purpose,

${ }^{1}$ Genealogy of Morals, i. 15.

2 Zarathustra, i. 15. 
a tyranny of will from which escape might be sought either in art or in asceticism. And what of those who still believed in Christianity? They, too, were racial decadents, for they placed the centre of gravity in a supposed world to come, a world for which earth was conceived as but a preparation, a world infinitely more important, regulated by different principles, enjoyable only through transformed natures. They were disloyal to earth and to all that marked earth's healthy sons; they spoke of the "duty" to welcome all that was unnatural, subordination, poverty, even pain itself; for they would thus win entrance to a place where they would be "eternally indemnified" for suffering. Paradise was a spot of everlasting compensation for "the fools, the bungled, and the botched "; these had failed in life's even competition, but the dice were loaded in their favour in the greatest game of all; earth's misfits were heaven's favourites. Hence, to the discriminating eye, modern morality was revealed as an ingenious system of new nomenclature; the gloomy workshop where men fashioned their ideals disguised all that was low under a name of conventional glorification; timorous abjectness became humility, constrained subjection was called obedience, inability to revenge emerged with the title "forgiveness."

At least equally degrading were those notions about guilt, punishment, obligation, which had served a social purpose, but which should never be seriously cherished by emancipated, buoyant spirits. "Bad conscience," forsooth! A man should " digest his deeds as he digests his food "; " inability to have

${ }^{1}$ Genealogy of Morals, i. 14.

${ }^{2}$ Will to Power, 906. 
done with an experience is a sign of decadence."1 Look at the morbid records of self-examination, at the saints who were for ever introspecting their own souls, at the nerveless, self-accusing mood which persisted even in those who had outgrown intellectual Christianity. Bad conscience was the "most sinister and interesting plant of our earthly vegetation.". The higher type of man should feel that he owes nothing save to his own expanding nature; he has no "debts" to the outsider; let him reflect on how the notion of moral indebtedness had been shown to have taken its rise, and let him boldly draw the inference. Let him escape from the ascetic humbug of the priesthood; let his instincts become rejustified before his eyes, once he has seen how and for whose ends those instincts were at first depreciated. Let him realize that the whole system of rewards and punishments was made to subdue the disorderly mob, that it has no relation to superior man who acts from an overflowing vitality without any thought of external results. But of such rejuvenescence there was so far little sign; the old superstitions widely prevailed, the " backworldsmen " were still dominant, and until they could be deposed from their usurpation mankind was on the downward path.

\section{III.}

To criticize all this within the limits of a lecture is, of course, impossible; it would involve the development of an ethical system. I can only indicate a few of the more important points.

${ }^{1}$ Will to Power, $233 . \quad{ }^{2}$ Genealogy of Morals, ii. 14. 
That concrete study of morality which our philosopher so loudly demands is a genuine desideratum; $m$ we have had abundant discussion on such matters as the moral standard and the moral faculty; but we have had comparatively little tracing, from an empirical standpoint, of the ups and downs in moral feeling from age to age. If Nietzsche has given us a correct account, even in outline, of the rise and fall of values, he has contributed something to knowledge which we have long needed and which we should highly prize. Has he done so ?

To write this chapter of human history is an extremely difficult task. You require, in the first place, a vast amount of anthropological learning; for you must begin at the source, you must know what there is to be known-and it is already immense-of the different ways in which primitive races valued conduct; you must connect these with the states of society in which they respectively appeared, and you must trace the changes which they underwent as social organization grew. Again, you must be an

* expert psychologist; you must understand the springs of action; you must be able to distinguish with confidence that behaviour which is physiological and reflex from that which is conscious and instinctive, and this, again, from that which is deliberate and rational; you must have a coherent scheme of the way in which instincts and emotions combine: if you have not this equipment you cannot thread your way through the multitude of historical facts which anthropology brings to your notice. Lastly, though the limits you have set yourself are empirical, though they exclude a metaphysic of morals, you must be in 
no small degree a metaphysician in order to observe those limits and to know when you are transgressing them. I quote in evidence those histories of morality which have so far been produced. Each qualification that I have named has often been found alone; just because they have never been completely united in a single person every history of moral ideas has been in a high degree abortive. The great work by Professor Westermarck is, beyond doubt, the finest effort that has yet been made in this direction; but every competent critic can see how unequal are its merits, how one aspect puts other aspects to shame, how full, for example, is the author's knowledge about savages, how slender by comparison his grasp of Greek or of Christian ethics, how much more adequate is his anthropology than his psychology, how constantly he ventures some crude metaphysical dogma with no thought that he is going out of his province. If even Professor Westermarck's powers have been thus overtaxed, the enterprise must be arduous indeed; we may say that this work has never been satisfactorily done because we have never had a man of accomplishments sufficiently wide and sufficiently varied to do it.

How far was Nietzsche's preparation adequate for the task? He has not, indeed, definitely undertaken it, but he has given us repeated summaries of the result to which this inquiry would lead, and he has risked many confident generalizations which could rest only on the basis of such assured knowledge. Yet few will maintain that in any of the three disciplines which I have mentioned he had or could have had more than the attainments of a smatterer. Professor Lichtenberger plainly wishes to say the 
best he can for Nietzsche, but even he has to admit this: "He specialized only in philology . . . in all other branches of science he was merely a dilettante, and of this he made no secret." In thus choosing for himself a sphere demanding an exceptional mass of erudition, he has had the fate which always awaits the tyro. He has had it in the more marked degree because of his incredible self-confidence. That amid all the topsy-turvydom of his thought Nietzsche had flashes of rare insight, I fully admit. But he valued himself just in the sphere of his inefficiency; the thing that he was not qualified to do at all was the thing for which he thought himself destined above all other men who had ever lived. Let us look at a few examples of how he did it:

1. Anthropological. - Nietzsche's picture of the first stage of morals is three-fourths mythology. There is no evidence for an original reign of sheer brute force, for a period or a class which valued simply the qualities of an overmastering aristocrat, for a " magnificent blonde beast." Patient study of early culture, both in its records and in those uncivilized races which still survive, has shown that man in his most primitive type had all the features of "herd morality" which our author attributed to a late epoch of decadence. Rude peoples are better understood now than they once were; they used to be estimated simply from their behaviour to foreigners, or from the character which they acquired through contact with civilization. Anthropologists who have observed them at home, and in a stage still untouched by outside influence, tell a very different story regarding them. I refer you for genuine material about

1 The Gospel of Superman, p. 196. 
incipient morality to such works as that of Messrs. Spencer and Gillen, The Native Tribes of Central Australia, or to the relevant parts of Professor Westermarck's Oxigin and Development of the Moral Ideas. You will there find abundant proof that primitive man is very often generous and sympathetic, given to peaceful pursuits, kind to the aged, attentive to the sick, considerate to his slaves and womenfolk, even severe towards thievishness, hospitable towards the stranger, and in some cases humane in war. Where his actions are the reverse of all this, we can often explain them from some superstition by which he is ruled, or from want of intellectual insight into the consequences of what he is doing; in neither case need kindly feeling be supposed absent. It is pure nonsense to pretend that in any age men esteemed nothing but the vital forcefulness of a warrior caste; the "plebeian virtues" abound from the beginning among the chieftains themselves. It is, of course, true that in a rude age war was specially important, and physical courage was specially valued; but Nietzsche's dogma of an original brutality out of which priest and demagogue conjured a decadent restraint is in the last degree imaginative. He simply adopted the current view about " the savage" from men who knew nothing at first hand, and he insisted on its truth because it fitted the groove of his a priori theory about moral growth. As we are now aware, the real distinction between savage and civilized morality is not so much that new forms of virtue have been produced as that the area over. which the old forms were applied has been vastly extended. Equally baseless is Nietzsche's view on 
the origin of the State. He rejects Rousseau's Contrat Social, but not for that reason which is really fatal to it; he rejects it on the wholly false ground that the first rulers were forceful blonde beasts who would not have stooped to bargain with anyone. And he sets up in its place the notion of the State as arising wholly from superior strength on the part of a few. He fails to recognize the fact of primitive gregariousness, of what Professor Giddings has happily called "the consciousness of kind." In the light of this we see that, strictly speaking, no origin for the $>$ State need be sought-that it expanded automatically out of family life, which was social from the first. And can anything be more plainly anachronistic than our author's explanation of " the moral 'ought' out of the very material "owe" "? According to this doctrine, men first thought of themselves as under moral obligation because they were obsessed by the idea of debtor and creditor; one may well ask, Had primitive man no sense of duty until he had developed contractual relations? The historical evidence is decisive; Sir Henry Maine, in his argument against Rousseau, has clearly pointed out that rights were first based not upon contract but upon status; it is modern man that has worked out the machinery of bargain and trade as a means to define relations that were recognized far earlier in another form. Moreover, the moral "ought" cannot be got out of a non-moral "owe" except by a play on words. Thus, Nietzsche spurns the error of Rousseau on a ground that has no value, and he himself reproduces precisely that blunder into which Rousseau really fell. Again, what shall we say of his theory about the rise of 
priesthoods? There is not a shred of proof that this meant a schism within the ranks of aristocracy; very much may be said-as all readers of The Golden Bough are aware-for the view that kingship itself was developed through the enthronement of a priest who was looked on as the incarnation of his own god. We have all learned from Sir James Frazer how manifold were the precautions which primitive folk adopted to ensure that their priest in whom the god dwelt should not suffer vital decay - how they even put him to death in the flower of his manhood that the spirit within might find a more robust tabernacle. What shall we think, then, of Nietzsche's bold assertion that priesthood means the revolt among men of low physique against the abounding vitality of a natural king? No doubt he had here specially in view the Christian priest; he expresses himself so loosely that it is often hard to be sure whether by religion he means religion in general or Christianity in particular; but his groundless thesis is advanced just in that section where he affects to explain the birth of religious as against secular morality; this cannot refer only to the rise of one faith-that one relatively late and preceded by many periods of asceticism. Moreover, it is hard to be patient with page after page of dogmatic assertion in which the religious consciousness of the world is attributed to deliberate imposture on the part of power-seeking priests. This field of inquiry is, no doubt, obscure; but we have got enough light on it to have cast off for ever the speculation of old Mandeville in his Fable of the Bees. Dr. Tylor's discussion in his Primitive Culture has laid bare the historical roots of early religious ideas in such a 
fashion that they are seen to be imbedded in early man's very nature; can we suppose that in every country and in every race a few persons were so far above their age as to have wholly escaped from its most intimate ways of thinking, and so cunning as to hit with singular unanimity upon just the same system of deception to establish lordship over their fellows? I shall return to this point in a later lecture; but the whole fraud theory of religion is now so antiquated in every school of anthropology that I am reluctant to argue at length against a view which it is no longer intellectually respectable to maintain.

2. Psychological.-When we turn to the psychological aspects of his position, Nietzsche's defects seem no less glaring.

He observed that when a particular way of valuing conduct becomes influential, the persons who exhibit such conduct increase in social power, and the persons whom such conduct favours begin to fare better than before. If mercy and justice rise in public esteem, then just and merciful persons are more valued, and those of the lower class who specially need mercy and justice improve their standing. This is true-it is even a truism; and from truisms no significant inference can be drawn. What is Nietzsche's inference? It is nothing less than this, that the moral estimates have one and all been created by the "will to power" of the persons who gain by their recognition. This is at best a very daring hypothesis, which the original truism might suggest; it requires a great deal of independent proof. What we are offered in its support is, in the first place, a mass of historical instances by which the hypothesis claims to be verified; examples 
are quoted where priests gained power through the dominance of asceticism, or the proletariate through the acceptance of a law of equality. But it is clear that these cases verify nothing, except the original tautology with which the whole argument begins, and which needs no confirmation whatever. The thing which demanded proof was the statement that one special result of a moral code-namely, the increased power which its adoption confers upon a certain class-was the efficient cause through which that code was created.

Nietzsche here ventures a sweeping generalization which, if sound, would certainly establish his case. He argues that will to power is the source not only of moral valuing, but of every act and every impulse in man or in animal. If this is so, morality, like all else, must beyond doubt be the will to power of someone, and it is reasonable to fix on the group which stands to win. But what does this single ubiquitous principle mean? Sometimes power is explained as selfexpression, and the impulse to it becomes almost identical with Spencer's impulse to a maximized life. Thus, the overwhelming of others is not essential; an explosion of dynamite does not " aim " at destroying property; it obeys its own law, and the shattered building is but an incident in the process; it would not have been shattered if it had not stood in the way. Does not human nature, then, recognize any limit to "expressing itself"? To keep his principle intact Nietzsche must reply either $(a)$ that it recognizes none willingly, though a man's energy may be coerced within limits by the rival energy of another; or $(b)$ that the apparent self-limitation is really self- 
development in disguise - it is will to power in another form. Now $(a)$ is plainly contradicted by introspection, and we have seen it fail even in that province of savage life which seemed most likely to vindicate it. Voluntary regard for others everywhere sets a bound to individual impulse. Shall we, then, fall back on $(b)$ and declare such regard to be a masked egoism? Nietzsche does so; where we imagine self-denial, he claims that egoistic impulse is behind; even the pitiful man is not disinterested, for he seeks exaltation in a sense of superiority, just as malice desires not the pain of another, but one's own augmented self-consciousness in view of that pain. The fallacy is as old as Hobbes, and we thought it had been refuted for ever by Shaftesbury and his successors; but let it pass. There is an element of truth in saying that a mother is egoistic in caring for her child, that it is her own image which she loves, and that a king or a general honours himself in devotion to his people or his army. A German who longs for Germany's success in the present war is in a way egoistic; he identifies himself with the Teutonic race, and if that race wins his self-feeling will be gratified. Will to power thus becomes not will to one's own power-the self being conceived as an individualbut will to power for the group or class to which one belongs. Herd morality appeals to the cripple, the pauper, the invalid, not because each of these looks for personal gain from a rule of mercy, but because, out of class-feeling and class-resentment, he wills increased consideration for all cripples, all paupers, all invalids over the normal, the rich, and the healthy. Observe that power has now lost its sense of self- 
expression and has become supremacy; "will to power" has become "will to war," not because obstacles are to be surmounted, but because of the lust for what our author calls " exploitation." Again and again, in defiance of the sense he gave to "power" at the beginning, he uses the notion of "exploiting" as identical with the notion of "power"; hence a constant source of ambiguity and confusion. But, returning to his idea of group patriotism, what psychological account shall we give of the men who oppose their class? What shall we say of those who seek to advance a group with which they cannot be held to identify themselves at all? What of the "wellconstituted ones who carry water to the mill of the world-despisers" ? To go no farther, how shall we explain Nietzsche himself, who belonged physiologically to just that inferior class which he so persistently abuses? He valued enormously those physical qualities which were antithetical to his own. If it be said that he was spiritually of the nobles though in body of the weak, what is this but to repeat the very paradox of which I ask an explanation? It is but to affirm that a man can detach himself from his class, can take an impartial standpoint, can judge things good or bad without reference to gain for his own order. Just as will to the pleasure of someone else is not will to pleasure, so will to someone else's power is not will to power. And how explain those ardent philanthropists, full of volitional energy, but striving in support of a class very remote from their own? On our author's own showing, herd values are uppermost even with those who do not belong to the herd at all. Omitting all whom demagogues have 
cajoled or priests have terrorized, what of those who fear no spiritual penalty, and who-say in Russiahave nothing to gain for themselves and less for their class by favouring a creed of equality? IIt is Nietzsche's own complaint that there are many such -men like Schopenhauer-who preach the plebeian virtues. How is it psychologically possible to account for their existence if the one principle of life is will to power? Each of these men is an instantia contradictoria. And how will it be possible to achieve that feat which Nietzsche thought the supreme call of the age-namely, the transvaluation of values? How induce lower men to sacrifice themselves for race elevation? If we are capable of a moral reason that is above our passions, this may enable us to change our valuing standard. If the sole motive is will to power for oneself or one's group, you may watch but you cannot modify the movements of that dominant impulse.

The truth is that our author, though he spoke much about "instincts," was quite ignorant of what an instinct psychologically means, and of what man's instincts concretely are. He knew that they were tendencies to act in certain ways, but he invariably names them after the antiquated method of selecting the end which an instinct serves, and importing foresight of that end into the impelling motive. Thus, he speaks over and over again about the "instinct for self-preservation," though no competent psychologist will now use such a phrase. We may act deliberately with the purpose of self-preservation, but an instinctive act is carried out with no anticipation of that end which, as the outside observer can see, is being effectively served. It is just here that the 
comparative study of animal life has cast special light upon the conduct of human beings. Let me quote a very suggestive passage from William James:

"A very common way of talking ... represents the animal as obeying abstractions which not once in a million cases is it possible it can have framed. . . . The cat runs after the mouse, runs or shows fight before the dog, avoids falling from walls and trees, shuns fire and water, etc., not because he has any notion either of life or of death, or of self, or of preservation. He has probably attended to no one of these conceptions in such a way as to react definitely upon it. He acts in each case separately, and simply because he cannot help it; being so framed that when that particular running thing called a mouse appears in his field of vision he must pursue; that when that particular barking and obstreperous thing called a dog appears there he must retire if at a distance and scratch if close by; that he must withdraw his feet from water and his face from flame."

We have recently learned much about human instincts; we know that the instinct for " power," or, as it is better put, the instinct for self-display, is only one of them; there is also an instinct of self-abasement which lies at the root of humility, and there are many others, equally primitive, as any psychologist can show, which have to do neither with self-expression nor with self-lowering, but with definite disinterested objects. By looking at these tendencies with a predetermined theory in your mind, you can, of course, estimate them all from the standpoint of increased or diminished power to the agent, but to put this element into their nature is to falsify them as psychophysical facts. And a great deal of recent advance in

1 Principles of Pyschology, vol. ii.: "Instinct." 
ethics has come from the interpretation of these as factors of co-ordinate rank in the moral consciousness.

Thus, instead of being, as his admirers assert, a master spirit in the unravelling of human nature, Nietzsche had all the vices of the amateur; in particular, he had the vice of hurry, and he had the vice of seeking some one principle by which all conduct should be explained. All scholars in this field know, and they know it with a clearness strictly proportioned to the depth of their learning, that such unification is a dream, that the threads are infinitely tangled, that there is no "open sesame," no master-key at which all these doors swing back. As was inevitable, Nietzsche tries to make good his case by reinventing one ancient fallacy after another, by laying down as intuitive truth some assumption that has long ago been exploded. "To the devil," he somewhere exclaims-" to the devil with all psychology !" Such radical clearance was indeed essential to the acceptance of his own "universal motive"; but we know what happens in a field like this when a man sets at naught all that the patience of his predecessors has disclosed. The remarkable thing in Nietzsche's case -and it is an evidence of his wayward genius-is, not that an account originating thus should be full of nonsense, but that amid the nonsense it should have suggestions of real value. I shall try to indicate what these are at the close of this lecture. Of the metaphysical objections to his ethic this is not the most suitable time to speak; they will meet us next day, and I shall not here anticipate what I must there set forth at some length. They arise chiefly 
through confusion between what the word "good" means and the conditions or circumstances in which it has been historically applied. Our author is so unsystematic that in discussing one side of his teaching we shall often be forced to return upon ground that we have already covered; it is just this mixing of different problems which I urge as proof of Nietzsche's metaphysical incompetence. But our principle that the history of moral ideas is one thing and the evaluation of those ideas is another must in faimess keep our minds unprejudiced towards that part of Nietzsche's system which we have still to see. His work may be full of mistakes from the standpoint of the anthropologist and the psychologist; yet he may have had genuine insight into the ethical problem of the present. Many writers have had this to whom the two sciences I have named were almost sealed books; and, though we may distrust a man whom we have found so dogmatic where he knew so little, we must give him an unbiassed hearing when he breaks fresh ground. That he had in some ways high capacity for interpreting the moral consciousness, not as it has developed, but as it permanently exists, I shall indicate some evidence from what we have already seen.

(a) Nietzsche has set in high relief the nature of morality as an active criticism of life, as a set of values which are not forced upon passive recipients, but are created by the mind itself. In this doctrine of values, rightly called by Mr. Schiller the greatest achievement of nineteenth-century thought, our author was one of the pioneers. Its importance is shown when we contrast it with some ways of think- 
ing that had preceded. In England Association Psychology had become dominant, and it had depicted the moral life of man as shaped for him by experiences from outside, as grooves and ruts worn into our nature by the action of forces which we could not influence. In Germany, on the other hand, the same phenomena were intellectualized, treated as unconscious deductions from the work of reason, robbed of the quality which most of all distinguishes them-that of the free play of emotion. Against both views Nietzsche asserts the spontaneity of the moral life, its character as coming from within, not imposed from without; its work as generating, not reflecting, values. He puts this well in his protest against an ethic which grounds itself on a vis inertice or on a blind mechanism.

(b) Arising out of this he has insisted with great effect that the moral values are only one species of values in general, that it is possible to evaluate values themselves, to adjudicate, for example, among the ideals of strength, pleasure, power, virtue. If any one of these is to be exalted to a primacy, it must be after consideration of the claims of the rest, not through acceptance of a rigid authority. He has put this, of course, in an exaggerated way; he has held it possible for mankind to differ indefinitely in their estimates. But it is a wholesome corrective to the view that they cannot differ at all, and it gives us the only key to interpret the empirical fact that they do differ very widely indeed.

(c) He has connected, far too rigidly indeed, but still validly, the appreciation of this or that virtue with the type of society in which it appeared. He 
has shown that qualities are not estimated in isolation, but as contributing to the kind of life which is for the moment most highly esteemed. Thus, a warrior age values courage, an industrial age values diligence, a democratic age values justice. And he has impressed upon us that the question we must answer in a moral judgment is not similar to the question of truth or falsity in a theoretical judgment; it is rather this: Is the quality in question advantageous for the particular mode of life which we think it valuable to preserve and to extend? Hence a moral code must always be in some degree fuid, no " Table of the Law," but altering as circumstance alters and as ideals become more enlightened.

These are important gains, not, indeed, the original handiwork of Nietzsche, but seized upon by him with special clearness and expounded with special vivacity and force. How far he has applied them in a fruitful way to the difficulties of moral thought in the present we have next to consider. 


\section{LECTURE III}

\section{THE TRANSVALUATION OF VALUES}

So far, we have seen the " (fill to power)" conceived by Nietzsche less as a (principle)which ought to dominate conduct than as a law which, as a matter of fact, (does determine the behaviour of everyone) The (moral is declared essentially the same as the immoral), just as Mill maintained that pleasure is the sole purpose by which mankind is psychologically capable of being moved, so, for Nietzsche, the desire to make oneself or one's class influential is the primitive motive from which all other motives have been derived.) And, as in Utilitarianism, a transition was made from psychological fact to moral rule, so we here find the circumstance that man always aims at power elevated into a maxim that power, and power alone, is desirable. Prima facie there is the same justification in both cases. If a certain principle is the only one from which man's nature allows him to act, it becomes impossible to argue that some other principle is prescribed either by his conscience or by his reason. The remaining step is to bring this universal purpose into clearer consciousness, to act upon it more systematically and more effectively. Hence the announcement of Zarathustra: "A new

1 Will to Power, 272. 
will teach I unto men: to choose that path which man hath followed blindly, and to approve of it.'

But Nietzsche's rôle was that of a prophet, a buccinator novi temporis; he dare not content himself with depicting life as a theatre of struggle in which first one and then another force wins the mastery; he must show which deserves the mastery, and how that which deserves it may be helped to obtain it. Thus, out of the ruin of previous valuations, he had to construct a valuation of his own, he had to offer us what Mr. Benn has neatly described as " the morals of an immoralist.". In this lecture I shall try to show how he differentiates in worth among the contending impulses which clash in the life of humanity.

He begins by warning us that so far he has merely cleared the ground. No inquiry into the origin of the ideas good and evil could by itself inform us whether these ideas were valid. ${ }^{3}$ The problem of psychogenesis was one, the problem of values was another. It was necessary to trace existing moral judgments back to their source, for they had come to us with an air of objective finality; the great dragon in Zarathustra's path was named "Thou shalt"; the striving of free spirits had been silenced by the voice that said: "All values have already been created."' One had to break down the spurious prestige of a system which pretended to a pedigree too authoritative for criticism. This could be done only by showing that the loftiest moral idea was man-made, that

\footnotetext{
1 Zarathustra, i. 3.

${ }^{2}$ In International Journal of Ethics, 1909.

3 Will to Power, 254. Cf. Joyful Science, p. 345.

${ }^{4}$ Zarathustra, i. $1 .{ }^{5}$ loc. cit.
} 
the same creative activity could bring forth other and contrary ideas. ${ }^{1}$ In what mould should it choose to fashion them? This was the problem of problems by which European culture was faced. A time would come when the decision would be no longer open, when man would " no longer give birth to any star"; the soil would have become impoverished and exhausted; nothing lofty would grow there again. ${ }^{2}$ It was the moment of choice when the world must elect either to go on with the old ideal or to " grave new values upon new tables." 3

Nietzsche declares that if the increasing decadence is to be checked, the plans of the future must have a single aim-that of stimulating vitality; we must produce the climate in which " the plant man will thrive." What have been the detrimental forces in the past? Only in a very minor degree the external things of the human lot, the grievous calamities beyond our control on which pessimism fixes its eye. These are, in a sense, normal-phenomena of old age and decay; they are no more fatal to rejuvenescence than the withered soil of winter forbids the promise of a spring. ${ }^{4}$ Nietzsche argues that the force which is really menacing to the future is a spiritual force, a thing resident in the soul itself; it is the worldrenouncing temper; if this could be cured, all else would come right automatically; if this must persist,

' $C f$. his "second metamorphosis of the spirit," Zarathustra i. 1: "Create new values-that even the lion is not able to do; but create freedom for itself for fresh creations, that the lion can do."

${ }^{2}$ Zarathustra: Prologue, v.

3 Ibid., 9.

- Will to Power, 40. 
all improvement of an external kind is mere palliation of the disease. The philosophers of the past had been so many blundering physicians who took as their task the concoction of some wretched analgesic, some soul-drug which should mask the symptoms while the inward canker was untouched. ${ }^{1}$ Radical treatment was called for, and this must consist, first and foremost, in a revaluation of two modes of feeling-sympathy and egoism. I shall take his account of these in turn, and then offer such criticism as seems appropriate.

\section{I.}

Schopenhauer had held that a spirit of universal pity is the thing plainly prescribed by a survey of life; for Nietzsche this was the exact opposite of the truth. The German word Mitleid means, literally, a "suffering with" one's neighbour, an entering into his state in such a way that his pain becomes in part our pain too. The man who pities has thus forsaken the individual standpoint, he has identified himself with another, he has voluntarily clouded his own world-enjoying spirit by exposing himself to infection from the morbid and the depressed. ${ }^{2}$ Nietzsche

1 Will to Power, 42.

${ }^{2}$ Cf. Genealogy of Morals, iii. 14: " Preventing the sick making the healthy sick-for that is what such a soddenness comes tothis ought to be our supreme object in the world. . . . May it perchance be their mission to be nurses or doctors? But they could not mistake and disown their mission more grossly - the higher must not degrade itself to be the tool of the lower ... the right of the happy to existence, the right of bells with a full tone over the discordant cracked bells is verily a thousand times greater." 
argues that just in so far as we do this, our efficiency in helping another becomes impaired. The surgeon who is over-sympathetic becomes unnerved and useless; the hand which can best save must be associated with an eye that is somewhat cold and a heart that is somewhat hard. Far from attempting so to realize in thought the distress of all our fellow-men that we may share it with them and help them to bear it, we must recognize that to do this would be to sink in hopeless despair, to unfit ourselves even for such service as we might otherwise offer. This is one point that Nietzsche has in mind when he speaks of the "follies of the pitiful "; " when he says, "Not your sympathy but your bravery has hitherto saved the victims " ${ }^{2}$ when he bids the wise man close his ears, however fierce an effort it may require, to the voice of another's pain. ${ }^{3}$

But not only did he look upon such sensitiveness as liable to lower vitality and hinder action; it was as a rule quite misplaced. Our philosopher becomes at this point very bold; he roundly declares that before we sympathize with anyone's hard lot we must ask ourselves whether the victim belongs to that type which ought to be preserved, whether he is cosmically valuable. Our test should be in part physiological and in part spiritual. In plain words, is the man a robust human creature? Or is there a reasonable likelihood that he may be made so? Is he, or is there a chance that he may become, one of the eager worldaffirming kind? Does he belong to the ascending or to the descending line of life? We must not hesitate

1 Zarathustra, ii. 25.

${ }^{2}$ Ibid., i. 10.

${ }^{3}$ Cf. Rosy Dawn. 
if the evidence is clear. In the one case we must assist him to rise, in the other we must assist him to fall quickly and decorously. ${ }^{1}$ As Mr. Salter puts it with a frankness which leaves nothing to be desired: "If we have any good thing in mind, we reject what does not correspond to it. If we set out an orchard we leave to one side trees that come maimed or broken from the nursery. If we send our apples to market, we exclude those under a certain grade."2

This is made specially clear in that passage of Beyond Good and Evil, ${ }^{3}$ where Nietzsche explains how the sympathy which should be approved differs from the sympathy which is to be resisted. For social distress, for the victims of disease, for the hereditarily vicious and defective, no compassion was to be felt; still less for the masses which strive after power under the pretext that they are aiming at freedom. The true sympathy was not concerned with suffering at all; it saw in suffering one of the chief agents of progress; it was affected only by the vicissitudes of "the type man," by the shame of seeing such a type dwarfed and retarded under a system of protection for degenerates. This is illustrated by a chapter in the fourth book of Zarathustra, which has won special admiration from Nietzsche's disciples; I grant that it shows a certain psychological insight, but I should place it morally among his more repulsive passages. The prophet has met in his wanderings a poor deformed creature, so misshapen that it required a second look to identify him as a man. "And all at

${ }^{1}$ Cf. Zarathustra, i. 21; Rosy Daun, p. 150.

2 "The Philosopher of the Will to Power," in Hibbert Journal, October, 1914.

${ }^{3}$ Section 225. Cf. also Will to Power, 367. 
once there came over Zarathustra a great shame because he had gazed on such a thing;" " Pity overcame him, and he sank down all at once." But he quickly recovered, his face became stern, and the poor sufferer thanked him because he had only blushed at the sight; other men had insulted him with their pity: "Thy shame, O Zarathustra, honoured me." The idea is that to the individual as such, whatever be his affliction, no compassion is due; we should be moved only by the thought that in him ideal humanity has been marred. And since it was by the men commonly called "good" and "just" that morbid sentimentalism was chiefly shown, Nietzsche exclaims: "Break up, break up, I pray you, the good and the just!'2 A revalued code would bid us cultivate a "sympathy against sympathy."

I must dwell a little further on this, both for its fundamental importance in our philosopher's thought and because it has been the subject of a very plausible misunderstanding. It is argued ${ }^{4}$ that Nietzsche's harshness is only on the surface, that he would replace a blundering, nerveless, effeminate pity with an intelligent, far-sighted, resolute effort to check unhappiness at its source. We are reminded that social disorders are often met by worse remedies; a temporary expedient often causes in the end more pain than it cures. When Nietzsche speaks of allowing the unfit to propagate their kind at will, when he calls for a judicious severity which will be merciful

1 Zarathustra, iv. 67.

2 Ibid., iii. 56.

${ }^{3}$ Cf. Ibid., iv. 62, and Beyond Good and Evil, 225.

4 E.g., by Mr. W. M. Salter in Hibbert Journal, October, 1914. 
in the end, when he reproaches us for pampering the present at the expense of the future-for an indulgence to ourselves which means cruelty to the unborn-we are all in a great measure with him. But the plea for the happiness of a generation to come is, on his lips, nothing more than an argumentum ad hominem; it amounts to this: "Granted that the great goal is to eliminate misery, I can show you that your method of indiscriminate compassion, your respect for the claims of the individual as such, is the best way to perpetuate misery." But, for himself, to make mankind happy was no part of the moral programme. ${ }^{1}$ Whatever Nietzsche may have been in private life, and we have evidence that he was not personally unfeeling, ${ }^{2}$ no system of thought was ever so deaf as his to the "still, sad music of humanity." His prescription of euthanasia is not in the interest of the sickly; it is in the interest of the healthful, to whom invalids are an encumbrance and may become a danger. He scouts the idea that suffering can ever be removed; he does not even desire that it should be; a race that was free from it would not be worth preserving; at times he wishes that pain could be made more intense and more poignant than ever before. A "happy life" was mere " naïveté of thought"; Herbert Spencer had proclaimed himself a decadent when he looked forward with satisfaction to a triumph of altruism, when he tried to believe that one day the conflicting interests of men might

${ }^{1} \mathrm{Cf}$. especially Beyond Good and Evil, 225.

${ }^{2} C f$. e.g., Frau Förster-Nietzsche's account of her brother as a hospital steward in the Franco-Prussian War. As George Eliot remarked of Dr. Cumming, it is satisfactory to find that our philosopher's practice was an amiable non sequitur from his teaching. 
be composed. That "pedantic Englishman" had drawn a "cheering streak" across the horizon of Evolution: "The final reconciliation of egoism and altruism of which he talks, that almost causes nausea to people like me."1

One might multiply such references to almost any extent; they are no occasional asides, they confront us repeatedly in almost every book that Nietzsche wrote, they are his essential message to the world, they supply the gravamen of his indictment against Christian morality. If they did not bear the sense which is apparent in them, it is difficult to see how a writer could have more unambiguously conveyed such a sense if he had wished; certainly our author had the gift of lucid expression. It is high time that those Nietzscheans who believe in an esoteric interpretation for such passages would give us an inkling of what that interpretation is. To me it seems clear that Nietzsche meant what he said.

A recent suggestion as to why he took such a view is that of Professor Lichtenberger, ${ }^{2}$ beyond comparison the most persuasive of those who have been commending Nietzschean ideas to the public. It is grounded on the extraordinary hypothesis of the "Eternal Return." Nietzsche's rigid determinism led him to believe that in the course of infinite time precisely the same collocation of atoms must occur again and again, so that the world must run through recurring cycles in which the same phenomena would be endlessly repeated. Every life would reappear

1 Twilight of the Idols, p. 87.

${ }^{2}$ In The Gospel of Superman, p. 187 (translation by Mr. J. M. Kennedy). 
just as it had appeared before; every experience must be gone through an indefinite number of times. Thus, the most wretched of human beings was deprived even of the hope of final annihilation; he must look forward to his recall, to a suffering anew of whatever he had suffered already. It was a paralyzing thought, and one which could ill consort with any type of Optimism-Nietzsche's or any other. Perhaps one can sympathize with a man who draws the moral that to abbreviate in any degree this human tragedy would be commendable. But one must remember that for Nietzsche the world-affirming temper accepts all, good and bad, as necessary parts in the drama; ${ }^{1}$ we must " say yea " to life, no matter how it is lived or how often it is to be lived; we must acknowledge that all things are equally in place. To do so is, of course, inconsistent with any selective morality; but the philosopher of Zarathustra says many things in turn, and Professor Lichtenberger may be right in so understanding one special mood.

\section{II.}

Side by side with his depreciation of sympathy, Nietzsche calls for a higher valuing of egoism. The current view might, he thinks, be crystallized into this: "Every man should be the preoccupation of his fellows."' But could moral thinking have become more absurd or more suicidal ? If one person deserved the interest and the care of others, he must be of value,

${ }^{1} C f$. Beyond Good and Evil, 56: "Wishes to have it again, as it was and is, for all eternity."

${ }^{2}$ Will to Power, 275. 
and, if so, why was he not worthy of his own interest and care? Hence Nietzsche speaks of " the seemingly -insane idea that a man should esteem the act he performs for another higher than the one he performs for himself, and that the same fellow-creature should do so too."1 Yet altruism might be judged in a sense right; among the common herd there was no great intrinsic difference of worth between one man and another; consequently the crude arithmetical method was usually best; where all were approximately equal, it was right to prefer the interest of several to the interest of one, and such was, as a rule, the option between selfishness and its opposite. But this maxim must break down where some individual is of vastly higher importance than the rest; it was incumbent upon such a person to choose with boldness an egoistic course. Thus, he writes: "Selfishness is worth as much as the man is worth physiologically who has it; it can have a very high worth, it can have no worth at all and be despicable." 2

By physiological value Nietzsche did not, of course, intend mere superiority in animal qualities, though he was so bent on reasserting the worth of the physical, and on repudiating a psychic entity which was not a function of the nervous system, that he has often used misleading terms. Return to an animal - past was not his ideal; the high ego was to be creative in every sphere-no mere dominant ruler, but beautiful, cultured, with " an overflow energy even for the most abstract thought." The essential point in his

\footnotetext{
1 Will to Power, 269.

2 Twilight of the Idols, ix. 33.

3 Will to Power, 898.
} 
reinstatement of egoism is that the eminent personality is to be prized on intrinsic grounds, not for any social service which he may be exceptionally capable of rendering. Nietzsche brands it as a species of Philistinism to look on either a great picture or a great man as valuable for the effect which is produced on the public; he claims that only the plebeian spirit of Buckle could have made it a burning question whether masses move of themselves or are moved by an individual genius-as if, forsooth, higher man was to be either justified or condemned for his " capacity of setting masses in motion "! Higher man's specific character lay just in his aloofness, in his incommunicableness; Napoleon was not justified as a figure in history for the work he did in the Revolution-rather the Revolution itself had its chief merit in the fact that it evolved a Napoleon; speaking abstractly, a man might be great though he effected nothing, he might be of the low order though he "shattered both hemispheres."

But while it was no part of a massive personality to seek any end except its own self-expression, yet, as a matter of fact, such personalities could not avoid leaving a mark upon their age. One may compare here the old Stoic principle of kindness to slaves as resting, not on any right inherent in the slave, but on the master's need to unfold his own lofty character. This is the key to Zarathustra's conception of egoism as "bestowing virtue." 2 The prophet had no love to men, yet he brought them gifts; ${ }^{3}$ he did so out of

1 Will to Power, 876.

2 Zarathustra, i. 22.

3 Ibid., Prologue, 2. 
a nature that was rich to overflowing, that had become spendthrift, that could not choose but bestow itself even on those that had no claim. Hence the narrow selfishness of the miser was to be abhorred, not because it was selfishness, but because it was degeneration, because it indicated a soul not full enough to become no longer self-contained. Will to power meant not will to accumulate, but will to discharge strength, and, though the egoistic higher man had no duties, save to himself and to men similar to himself, those below would incidentally benefit. Thus, Zarathustra declares:

"When your heart overfloweth broad and full like the river, a blessing and a danger to the lowlanders; there is the origin of your virtue."1

Nor must we lose sight of the fact that the privilege of the man eminent enough to be rightly an egoist is anything rather than the privilege of luxurious pampering at another's expense. He was called to a rôle far more exacting than if he had remained in the herd. The higher the personality, the more difficult it becomes to do that personality justice; average people with their average duties were by comparison happier because free fr om care, because irresponsible, "like a beast with lower pleasures, like a beast with lower pains." Thus, Nietzsche reminds us, "life always becomes harder towards the summit-the cold increases, responsibility increases "; like Garibaldi

1 Zarathustra, i. 22.

${ }^{2}$ Antichrist, p. 57. Cf. Will to Power, 944: "What is noble?

That one leaves happiness to the greatest number . . . that one instinctively seeks for heavy responsibilities." 
when he addressed the volunteers entering upon a great campaign, the prophet has to offer to his disciples suffering, martyrdom, indignity; a self-discipline such as the common herd could never know; because he wishes to develop in them " the only thing which to-day proves whether a man has any value or not-namely, the capacity of sticking to his guns." 1

This view is summarily presented in our author's criticism of the "Golden Rule." In its New Testament place this was the result of herd instinct; as reproduced by " that blockhead John Stuart Mill,"3 it was a niaiserie anglaise. For what did it assume? Surely that men are equal, and that the services they can render to each other are to be estimated on the basis of equivalent exchange? But men were not equal, and, if they were not, it followed that what one did to another that other might not-nay, often could notdo to him. Moreover, was not this whole way of looking at conduct a transforming it into a system of mutual services, a cash payment by each for something that he had received or hoped to receive, the polar opposite of "bestowing virtue" ? "The hypothesis is ignoble to the last degree." Thus there definitely emerged for Nietzsche the (doctrine of a double morality-one system for exceptional men, men worthy to consider themselves and themselves alone, men in whom humanity reached its highest and most refined expression; the other a system for the multitude, for those standing in the same relation to the exceptional types as the mass of quartz to the ore

1 Will to Power, 910.

${ }^{2}$ Ibid., 925.

3 Ibid., 30. 
that is embedded in it, for those who were no endsin-themselves, but at best a means to an end beyond themselves.) Mill's principle, "What is right for one is right for another," was laid down in defiance of psychological difference; ${ }^{1}$ it assumed the precise opposite of the truth-namely, that the development of one individual is of the same value as the development of another. This had even been pushed to the monstrous extreme of seeking by artificial emphasis on just those who were intrinsically least valuable to " compensate" for the distincticn which nature had made. Beginning with the false principle that all be treated alike, we had forsaken our own law, and forsaken it on the worse side; we had loaded the dice on behalf of the weak, the bungled, and the botched.

Hence the imperative need for a transvaluation of values. Let us lay down the sharp contrast between "master-morality" and "slave-morality." The watchword of the former must be bold, exploiting egoism, the watchword of the latter might be left at the old plebeian standards of justice, sympathy, humility, obedience. Let the few who are fit for emancipation have their eyes opened; let them see the rotten basis of the old ethic, the grovelling religious superstitions which gave birth to the creed of equality, of duties, of coming punishments and rewards. Teach them, rather, that on them and on their ruthless selfishness the burden of humanity's future has been laid, that in them, and in them alone, progress to a higher type can be achieved. For the multitude let the old dogmas be kept; they are the

1 Will to Power, 926. 
surest stay of order, by them more effectively than by anything else could the masses be made to keep a servant's place and to do a servant's work; so long as their minds are fixed on bliss beyond the stars they will be less disposed to fight for an undue eminence here and now. The danger of such thoughts was for those with strength of will, those who might argue from a coming glory in the future to the right of securing an immediate power on earth. Let any and every agency be used, let any and every lie be disseminated in order to cajole, to frighten, to coerce such insurgent energies. The (end was race advance in the persons of those who alone could advance, and that end justified every means.) Only let there be no mixing of the classes, no transference of the code appropriate to one into the consciousness and behaviour of the other.

\section{III.}

This revaluation of sympathy and egoism is, plainly, in sharp conflict with much that Christendom holds dear. At first sight one is disposed to say that it negates both in essence and in detail all that is distinctive in the moral tradition of the Church. This charge Nietzsche would have joyfully acknowledged, for he gloried in conceiving himself as the Antichrist, as the great opposing force which was to win back the world to paganism, as the whirlwind which was to sweep away the miasma that had arisen from the hills of Galilee. These are days when one keeps an open ear to all who have anything to say, if they say it honestly and intelligently; even in 
Nietzsche's evangel I shall try to show that there are elements of truth. I have tried to put his points moderately, with as much persuasiveness as I could import into them, eliminating very much of that rhetoric which his admirers believe, but which I do not believe, to be a source of strength in his position. Anyone familiar with the text will understand what I mean, and most, I think, will agree that this prosaic statement, if less than fair to him as a literary artist, is more than fair to him as a judicial moralist. His own language is so intemperate, so studiously offensive, and so invariably blasphemous, that many have refused to consider him at all, refused to see in his transvaluation anything that merits more than a passing word of indignation and contempt. It was certainly not too much to expect that a new thinker, setting out to reverse the whole morality of Western Europe, however confident he might feel in his own position, would show some sense of the magnitude of his task, that he would not habitually substitute for reasoned argument a virulent and even foul abusiveness. Nietzsche's way is to disdain the need of proving what he says $;^{1}$ his rôle is everywhere that of a prophet and a seer; his most outrageous paradoxes are proclaimed with an air of inspiration; if any cannot follow and cannot eagerly acquiesce, they are not to be calmly persuaded, but are by turns to be stormed at, ridiculed, pitied. It is not an ungenerous

1 Cf. The Case of Wagner, pp. 110, 111: "Honest men like honest things, do not carry their reasons in their hands in such fashion. That which requires to be proved is little worth." And Zarathustra: "Why? Thou askest why? I am not of those who may be asked for their whys." 
recalling of his melancholy personal history, it is much more one's observation of his methods throughout his literary career, which has prompted the suggestion that he was more or less mad from first. to last.

To the task, then, of determining how far this extraordinary revaluation has features that are true and important I must now address myself.

That sympathy may be overdone, that a too sensitive nature may defeat its own altruistic purpose, that one may brood on the miseries of the world to such a degree as to become morbid and unnerved, and that in consequence a certain power of withdrawing in thought from scenes of pain is wholesome and necessary-all this may be at once conceded. It is a merciful fact that we are psychologically unable to realize in imagination all the suffering which we know to be in progress; and there are, without doubt, persons who feel too much or too constantly for others whom they cannot aid. But if Nietzsche had meant no more than this-even though he put it in a particularly striking way-we should regard what he said as somewhat obvious and trite; we should be astonished to learn from him that his ethical message was one which in two years was going to " make Europe writhe in convulsions." That he did mean a far more sensational thesis I have adduced evidence to show; he meant to condemn sympathy for distress as such, he meant to recommend an attitude of contempt for individual pain, however excessive, and of respect only for an ideal of race fitness to which the individual's lot was insignificant. This implied, as Nietzsche was the first to insist, a complete denial of 
what are called the " moral axioms." I shall consider in a few minutes how far this can be rationally defended; but first I wish to look at the other aspect of his transvaluation-namely, his increased emphasis upon egoism, where those who still stand by the accepted values may find some real insight.

(a) Nietzsche has here forced into high relief the obligation to cultivate and express one's own personality. There is, of course, a sense in which human nature may be trusted to keep what are called "duties to oneself" in a conspicuous position. But our author does not mean that indulgent mood toward one's inclinations and weaknesses for which this phrase too commonly stands. $\mathrm{He}$ does not mean the selfishness which, as a matter of fact, is habitually practised; he means a higher selfishness which should be practised. His maxim, Be hard, is to be applied inwardly not less than outwardly; it prescribes a vigilant search into what a man's individual nature has it in itself to become; and he boldly declares it a duty to realize one's highest latent power, not merely that it may be used in altruistic fashion for mankind, but that it may find expression for its own sake. I think he has here fastened on an element of neglected truth.

We often speak of the pursuit of knowledge, of artistic culture, of the work of the poet and the man of letters, as morally below the effort of a selfdenying philanthropist; we often regard these as the luxuries of life, and the men who make them life's main business as no more than intellectual sybarites. We exalt in contrast the persons who "do good," who live not purely or chiefly for themselves. But 
we sometimes state this undoubted truth in so extreme a fashion as to imply that a man's own wellbeing and the development of his own personality is an object which it is blameworthy for him to consider. Against this perversion. Nietzsche supplies an important corrective. He finds the good for all effort in the production of a certain type of life, a certain type of human being.) If he is right in this, the good man is he who not only helps others to reach this goal, but who endeavours to reach it himself. To deny by implication one's own value is not an inference from, it is ultimately inconsistent with, all morality. To exalt self-denial until it absorbs the whole of virtue is, as he says, and as too many forget, a suicidal mode of moral thinking. If the development of another's personality is a duty for me, this must be because developed personality is a good, and, if so, my own is intrinsically not less valuable than that of my neighbour.

There is a striking passage in that sad but penetrating book, De Profundis, where the writer disputes, and to my mind with reason, the view that self-denial was the essence of the moral teaching of Christ. $\mathrm{He}$ says:

"To live for others as a definite self-conscious aim was not his creed. It was not the basis of his creed. When he says, 'Forgive your enemies,' it is not for the sake of the enemy, but for one's own sake that he says so, and because love is more beautiful than hate. In his own entreaty to the young man, 'Sell all that thou hast and give to the poor,' it is not of the state of the poor that he is thinking, but of the soul of the young man-the soul that wealth was marring. In his view of life he is one with the artists who know 
that by the inevitable law of self-perfection the poet must sing, and the sculptor think in bronze, and the painter make the world a mirror for his moods, as surely and as certainly as the hawthorn must blossom in spring, and the corn turn to gold at harvest-time, and the moon in her ordered wanderings change from shield to sickle and from sickle to shield."1

Thus, to respect one's individual value, to look upon one's powers not as that which may be cultivated or neglected at will, to make oneself efficient along the line of one's special gift- these are suggested morals in Nietzsche's egoism. The same idea is put more prosaically by Bishop Butler when he exclaims that mankind has really rather too little than too much self-love. ${ }^{2}$

This idea meets us in another form in Zarathustra's passionate individualism, in his dismissal of the disciples who would cling too long to his own tuition. He will have no cast-iron systems which aim at producing a uniform human type. A teacher, he declares, is poorly requited by those who remain permanently his scholars; they had not yet sought themselves when they found him, let them now lose him that they might find themselves; thus would they best honour his word. ${ }^{3}$ One may compare the words of the writer I quoted a moment ago: "Most people are other people; their thoughts are someone else's opinions, their lives a mimicry, their passions a quotation."4 And Wilde, who amid many differ-

1 De Profundis, pp. 84, 85.

C 2 Sermons on Human Nature, i.

3 Zarathustra, i. 22.

4 De Profundis, p.83. 
ences has some affinities with Nietzsche, provides a comment upon this point of view in his book, The Soul of Man under Socialism.

(b) Moreover, we may acknowledge that the right to develop one's individuality applies with particular force to a man of specialized distinction. A Goethe, a Mozart, a Turner, may without impropriety be said to "owe it to himself," or to "owe it to the divine gift that is in him," that such genius should be cultivated and expressed. This is in no way inconsistent with the Golden Rule, or with the morality of the Mount. The great poet or the great painter contributes in just as real a sense as the philanthropist to the treasury of the world's values. A Puritan who sees no merit in the beautiful as such is paying scant reverence to Him who for no utilitarian purpose fashioned the lilies of the field. And it is but common sense to say that if works of art are worth producing, the men able to produce them should be held in honour, should be encouraged to develop their special powers along their special line. That in this sense the production of high creative personalities is an end which social arrangements should keep in view, and that to some extent-for instance, in freeing them from pecuniary anxieties-we should provide such persons with exceptional privilege and opportunity, no one but a fanatical communist will question. When Nietzsche denies the existence of a uniform code fixing every man's duty as the same with everyone else's, supplying a "moral ready-reckoner"1 which shall prescribe for all alike-no matter what

1 The phrase is Mr. W. H. Fairbrother's, in The Philosophy of Thomas Hill Green. 
the individual endowment of each may be-he is a true psychologist of conduct. General Booth was, beyond doubt, of higher moral value than John Ruskin, but to send the author of The Stones of Venice into the slums of the East End might have been just as foolish as to appoint the Salvationist Professor of Fine Art at Oxford.

(c) In another way our author has scored a distinct point against the altruism which claims to be a complete formula for the whole duty of man. He correctly brands it as self-contradictory. If one person is to serve another, this involves that the other is willing to be served, and it can scarcely be wrong for me to accept what it is morally imperative for another to bestow. Persons who will receive nothing are, as Mr. W. M. Salter remarks, " really the most embarrassing people in the world-they frustrate our own virtue !" That Nietzsche is here tilting against no imaginary antagonist anyone can see who looks into the moral teaching, for example, of Francis Hutcheson, or even of Henry Sidgwick. ${ }^{2}$ Wherever benevolence is made not a part but the whole of virtue, we may fairly ask who will be the objects of this benevolence, and how will they justify their acceptance of it; wherever self-sacrifice is commended as the sole worthy impulse, we may ask who, realizing that principle, will allow another thus to be negated for him, who will not rather insist on being himself

1 "The Philosopher of the Will to Power," Hibbert Journal, October, 1914.

${ }^{2} C f$. Dr. Hastings Rashdall's Theory of Good and Evil, vol. i., 55, where it is argued with great clearness that Sidgwick's utilitarianism implies different objects for the individual and the race. 
the loser. Thus, a world in which everybody was benevolent, everybody self-sacrificing, and none influenced by any other motives at all, becomes an impossible conception. Altruism in the end involves an egoistic factor.

(d) Finally, Nietzsche has rendered no small service in challenging the common view that moral values should be held for ever immune from criticism or revision. We saw last day how he has presented us with a series of ethical tableaux, in which the ups and downs of past valuing are vividly portrayed. These pictures were drawn with a very uncertain hand; for our artist had not the knowledge to draw them accurately; at the same time, the broad variations are often genuine. Now, to emphasize such variety as actual was important; but it is still more important to draw the ethical inference that we have a right to change our values as our insight grows deeper and surer. I shall argue to you presently that such estimates are the work of reason; if so, they should, no doubt, be stable in the same sense in which the gains of reason elsewhere are stable, but in no other, no more rigid or more inviolable sense. If we have been able to improve upon our geometrical consciousness, there is no ground to deny that we are also able to improve upon our moral consciousness. And humanity's advance in the knowledge of good and evil has, as Zarathustra says, been impeded by the great dragon named "Thou shalt," the dragon upor whose scales glittered the values of a thousand years, the dragon that declared, "All the values of things glitter upon me." Was it not one of these, for ex-

\section{Zarathustra, i.}


ample, which, calling itself the "sacredness of property," stood in the moral path of Abraham Lincoln? Is it not in the strength of one or more of them that a thoroughly conscientious opposition is always available against an innovating reformer ?

That Nietzsche should have fastened upon the Christian religion the stigma of such narrow legalism is one of the strange ironies in his teaching. To me it seems that in thus proclaiming the autonomy of the valuing will, he might have appealed with effect to Him who broke the fetters of Judaic Rabbinism. That he did not recognize this was, of course, due to his radical rejection of those values which Christ made influential in the world. But the clear message of the Galilean gospel is to emancipate from bondage to "Tables of the Law," to encourage the autonomous moral reason in its search for ever-widening truth. And we shall be faithful to the spirit of that message if we test Nietzsche's revaluation, not by a rigid authoritative code, but by its power to convince that discerning conscience from which all codes derive their right. If we reject the lowered value of sympathy and the raised value of egoism, it is not because the older scale has been imposed upon us from without and has made us intolerant of free inquiry into its credentials; it is because the more thoroughly we use every method of inquiry suited to such material, the more firmly do we establish the right of human brotherhood and the primacy of the Golden Rule.

Such points of merit are insisted on by Nietzsche's sober-minded admirers, by critics like Professor Lichtenberger, who have not forgotten their judg- 
ment in the enthusiasm of the devotee. But most of the Nietzschean zealots would, beyond doubt, feel less indignant with those who flatly denounce their master than with those who thus whittle him away; they would tell us that Nietzsche is not to have the whole heart taken out of his teaching and then be complimented for a few obvious commonplaces that are left as residue, that for him above all men " that honour rooted in dishonour stood." I acknowledge that in a sense they are right; Zarathustra had something far more profound to say than anything I have yet indicated as valuable. What was this? And to what criticism is it exposed?

1. "A new will teach I unto men; to choose that path which man hath followed blindly, and to approve of it." Taken in connexion with what our author says elsewhere, this must surely mean that from scrutiny of man's actions in the past there will emerge a principle which has universally guided him, and that this principle is eo ipso justified. Hence, as one of his expounders has put it, for Nietzsche " life is to be accepted in its entirety; one must not regret anything, not even bad passions and dangerous instincts; whatever else he does, man never sins." I ask you, could one more effectively cut away the basis, not from this or that ideal of conduct, but from the very notion of any ideal whatever? Could our author have more completely incapacitated himself in advance from arguing that anything is " better " than anything else? And yet that some things are thus superior to others Nietzsche has with great passion insisted!

Distinctions in value between types of character or conduct may or may not be valid; we leave that 
question for the moment open. When I say "valid," I mean that such distinctions may or may not have the same sort of quality that a proposition of Euclid has-a right to claim the concurrence of all alike. If the statement, "Theft is wrong," has this quality, it can no more be the outcome of mere strivings after power on the part of various classes than the statement, "Two triangles on the same base and between the same parallels are equal," can have resulted, e.g., from the priest's wish to depose the noble, or the demagogue's wish to depose the priest. Our author, indeed, is very thoroughgoing; in his account of "Will to Power in Science," he argues that the "truth" of a scientific proposition is nothing more than its effectiveness in rendering man influential; whatever this extraordinary view may mean, at all events its issue must be to destroy the objectivity of science. In the same way what becomes of the judgment, "Theft is wrong," from the standpoint of a burglar whose will to power finds in theft the most productive instrument? One can only escape from this difficulty by declaring that the burglar's will to power is a thing intrinsically inferior to the will to power of the law-abiding classes; how shall we defend such a view unless we recognize that mere self-seeking as such is not the only motive by which man can be or should be influenced-that even from the standpoint of him who is going to lose power by admitting it a moral judgment may be valid?

In last lecture I argued to you that Nietzsche's psychology of motive is utterly wrong; I further > claim that even from a psychology that is right no ethic can automatically follow. An investigation of 
the impulses which, as a matter of fact, we have obeyed, cannot inform us which of these impulses we should obey; the whole point of morality-Nietzsche's "morality" as well as any other-is to pick and choose among actual motives and actual modes of behaviour. To do this involves a criterion, and the test by which material is judged cannot be given simply in the material itself. With his usual inconsistency Nietzsche has himself given striking expression to just that principle by which his own procedure is condemned. In the ninth section of his Beyond Good and Evil he pours scorn on the Stoic motto about life according to Nature. Nature, he points out, is indifferent; but imagine indifference as a power! Was not to live just an endeavour to be otherwise than this Nature? Was it not selection, valuing, preferring? "Why should you make a principle out of what you yourselves are and must be ?" (the very thing which our author has himself done). Could not anyone see that the Stoic scheme of life was not life according to Nature, but life according to the Stoa? Thus, thought must always " create the world in its own image." The passage is very striking and quite fatal to whole volumes that its author has written; it reminds one of Matthew Arnold's exclamation:

Know, man hath all which Nature hath, but more, And in that more lie all his hopes of good. ${ }^{1}$

That Nietzsche's own criterion was not borrowed, as he alleges it should be, from an inspection of the

${ }^{1}$ Sonnet to an Independent preacher who preached that we should be "in harmony with Nature." 
actual is abundantly clear. He valued egoism higher than altruism. Why? Not because men are egoistic, but because he held it an intuitive truth that the ego of some men is more valuable than the ego of others. The values of beauty, strength, etc., are reviewed and adjudicated upon; some are pronounced noble, some ignoble; amongst all of them onenamely, race fitness in a few selected individuals-is declared highest; all this implies a power resident in $\rightarrow$ reason to choose among the products which have all alike come from the workshop of Nature. As facts not one of these can be called either less or more real than another; but as values some of them to the eye of insight are declared so far above the rest that the torrents of Nietzsche's abuse may fitly be showered upon him who makes the unworthy choice. Thus, an ethical principle, which is no derivative from psychological analysis, is installed as paramount.

2. Our philosopher, then, in so far as he is con>structive, shares that faith in an ultimate category of value which in his destructive mood he disavowed, but which is essential to the building up of any ideal system. Our task as critics must then be to consider how far this particular conception of the highest value is, concretely, acceptable.

To discuss at large the standard of conduct would take me much too far afield; it is enough to concentrate attention upon one feature in that standard, a feature agreed upon by practically all moralists with the exception of Nietzsche, and to ask whether his dissent from it can be justified. Thinkers of every school have been at one in insisting that the good, whether it be pleasure, or happiness, or self-develop- 
ment, or whatever it may be, must be distributed in accordance with a formula of justice. Sometimes they have expressed this in the language of Kant, that every man must be treated as an end-in-himself, not as a mere means to the end of another; sometimes they have used the maxim of Bentham: "Everybody to count for one and nobody for more than one;" but, since the principle of slavery has been abjured, no thinker of consequence has grounded his system upon the idea of one class with intrinsic rights and another class with no intrinsic rights at all.

If one is asked how the authority of this law of justice is " proved," the answer is that it cannot be proved, in the sense of being exhibited as an inference from some higher and more assured premiss. It is an axiom of moral thinking in the same way in which causality is an axiom of scientific thinking. You do not demonstrate either from something else; you demonstrate other things from these as startingpoints. Thus, when Mill declared the greatest good to be a sum of pleasures, it was cogently objected that, though a greater hedonistic sum might result from multiplying the pleasures of a few and reducing those of the many, to do so would be to outrage the moral consciousness. Though the delights of Cæsar Borgia could be increased without limit, this would in no way compensate for the pain of the victims by which such delights were made possible. And though the self-expression of a transcendent ego could be helped to a pitch so far undreamed of, this would be no satisfying offset to what Nietzsche called "the reduction of the multitude to incomplete men, to slaves." So affirms the moral consciousness as an 
ultimate irreducible statement of value. You can deny this only by denying the existence or the authority of such a consciousness. Now, that Nietzsche admits an objective category of value we have already seen; but he denies this to be of the "moral " order. Morality was for him mere interpretation, and false interpretation, of the basal fact. But for such a view - he has not produced a shred of real evidence.

I said enough in a previous lecture to disprove the monstrous anthropology and the equally monstrous psychology by which a pudenda origo was attributed to such notions as responsibility and guilt. These notions are present in the mature mind of to-day, and that they did not take their rise as Nietzsche says they did, all competent persons are agreed. But we are now past the historical question; we are now asking, not how these ideas came into the consciousness of man, but what their content is in that consciousness to-day. I contend that "good" in the $>$ moral sense is a specific unanalyzable category, like "cause" in the scientific sense. It is thus indefinable, as all ultimate ideas are; attempts to define it end either in assigning a mere synonym, or in specifying, not the meaning of good, but some of the conditions under which the judgment of good is passed. Mr. G. E. Moore puts this point with exceptional clearness when he writes:

"It may be true that all things which are good are also something else, just as it is true that all things which are yellow produce a certain kind of vibration in the light. ... We may define it" (i.e., yellow) " by describing its physical equivalent; we may state what kind of light-vibrations must stimulate the 
normal eye in order that we may perceive it. But a moment's reflection is sufficient to show that these light-vibrations are not themselves what we mean by yellow. They are not what we perceive. Indeed, we should never have been able to discover their existence unless we had first been struck by the patent difference of quality between the different colours." 1

Now, is it or is it not a fact of introspection that in every developed mind this notion of "good" exists, and that we are as incapable of believing that conduct to be good which wholly disregards the right of any class, which simply makes one class the tool of another, as we are of calling that object a triangle which is found to be made up of four sides? The question is not whether in practice we shall ignore the distinction; as Professor D. G. Ritchie has said, "A truth is not less true because someone acts as if it were false"; the question is, whether its theoretical validity does not come home with coercive power to the mind. To me it is plain that in the developed consciousness this is recognized with perfect clearness, that in the most primitive race we can already see it in germ, and that its strength, like that of other axioms, has grown in proportion as intelligence has advanced. We can no more prove it, but at the same time we can no more doubt it, than we can either prove or doubt that 5 plus 4 equals 9 .

Thus, when the plain man dismisses as absurd the view which would make egoism supreme, he is obeying the same unreflective common sense by which he turns away from an argument that such and such a physical event occurred without a cause. In both

${ }^{1}$ Principia Ethica. 
cases it is the task of philosophy to elicit the reasoned principle which is latent in the ordinary consciousness; the position of complete scepticism is one for which a case may no doubt be made, though it is beyond my present purpose to examine it; but the first truths of morality stand on no less and no more precarious ground than the first truths of reason in any other sphere. 


\section{LECTURE IV}

THE S U P E R M A N

Every moral system has its Utopia; every specific principle of valuing points to a specific ideal. Thus, when we have appreciated the doctrines of a moralist, we should be able to define in terms of these what the life of humanity would become if they were generally accepted and generally acted upon. Stoicism had its

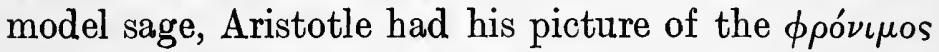
and the $\mu \epsilon \gamma a \lambda o ́ \psi v \chi \chi o s$, Christianity has its conception of the Saint. What would the world look like if Nietzsche's great moral displacement were carried out? He has himself supplied us with a very vivid and a very startling image. In this lecture we shall study his "Superman." I shall first describe what Nietzsche meant by the term, and then offer some criticisms upon such a way of envisaging the ideal.

I.

One of his translators has called Nietzsche "the first consistent Darwinian"; the compliment, we may be sure, would not have been welcomed, for in our author's view Darwin had been a great misleader of European thought; he had misled it in just that fashion which might have been expected from an Englishman, for "he was an intellectual plebeian, 
like all of his nation." Before considering the points in which the German thinker tried to amend the evolution hypothesis, we must notice some matters of fundamental agreement. Darwin thought of life as pre-eminently a struggle, in which the weaker elements tended to succumb, and the stronger tended to survive. In the animal and vegetable worlds excellence of form and structure had been reached, not abruptly, but gradually; the adaptation of all growing things to the environment in which they flourish was not the result of a divine plan, assigning each from the first to the place that fits it; we must rather look upon the forms of life as having been strewn here and there in wild profusion, until by far the greater number had proved themselves unequal to the conflict with circumstance, had perished through incapacity to meet the demands of some particular habitat, and had been superseded by just those special types which the soil, the climate, and the local surroundings permitted. Thus, the production of even one animal or plant which should be precisely appropriate to the situation in which it was placed, must have been achieved through a long series of siftings and rejections; the pathway to each of Nature's successes was littered with a multitude of Nature's blunders. This is that apparent waste to which, in the botanical sphere, Tennyson alludes when he writes:

Finding that of fifty seeds She often brings but one to bear;

and again in the animal world:

So careful of the type she seems, so careless of the single life. 
On one side this is plainly a pitiless process, everywhere favouring the robust, everywhere repressing the feeble. When we think of its action among men and societies, it appears as that force which makes the rich progressively richer and the poor progressively poorer-the principle of Rob Roy:

For why?-because the good old rule

Sufficeth them, the simple plan,

That they should take, who have the power, And they should keep who can.

$* * 4 *$
$*$
All kinds and creatures stand and fall
By strength of prowess or of wit;
'Tis God's appointment who must sway,
And who is to submit.

At the same time this merciless rule of force has seemed to some evolutionists to be the condition of all improvement in the racial type. They tell us that (competitive selection brings to the front all that deserves to get to the front, that it eliminates the things which ought to perish.) And the moral they draw is that his working of Nature should not be interfered with, but should rather be seconded, by the machinery of civilization.)

Now, in some of his moods Nietzsche has, beyond doubt, adopted this view. He applies it, for example, with a remorseless hand to the problem of Eugenics. Zarathustra discovered that the earth was "full of superfluous people;" thesewere not only the weaklings in body, but the " spiritually consumptive ones,", men who had learned from Schopenhauer or from

1 Zarathustra, i. 9.

${ }^{2}$ loc. cit. 
St. Paul to be world-weary, life-despisers. Let them be encouraged to suicide, for they were clogs upon the energy, physical and moral, of the rest. ${ }^{1}$ It was the greatest nonsense to speak of every individual as having an independent, sacrosanct value; each in turn must submit to a scrutiny as to whether he was physiologically worth keeping. Nothing could be more immoral than the haphazard fashion in which a man chose his marriage partner; the hope of the future was sacrificed to the fancy of the present; there was no thought of fitness for parenthood. ${ }^{2}$ The prevailing license set a premium upon the decadent; it was just these who could not resist the smallest sexual attraction. "Society as the trustee of life is responsible for every botched life before it comes into existence, and as it has to atone for such lives, it ought consequently to make it impossible for them ever to see the light of day." "3 Let the motto of the future be, "Not only onward shalt thou propagate thyself but upward."4 In this connexion Nietzsche says some very direct things about the place and function of women. The female sex was mentally feeble, occupied mainly in adorning itself with dress, inefficient even in that art of cookery which it had so long monopolized, given to petty jealousies, deceitful beyond description. ${ }^{5}$ It had all the vices of decadence-witness woman's susceptibility to the influence of a priest. ${ }^{6}$ The Oriental spirit in sex

1 Zarathustra, i. 9 and i. 21

2 Will to Power, 732.

${ }^{3}$ Ibid., 734.

4 Zarathustra, i. 20.

5 Beyond Good and Evil, 232-234.

6 Cf. Will to Power, 864. 
relationship was right; as the Greeks advanced in culture, they transformed the absurd equality of Homeric times into the definite subjection of the age of Pericles. ${ }^{1} \quad$ Woman's whole purpose was that of a child-bearer; her preparation in youth should keep that single object in view. ${ }^{2}$ Modern "feminism" was one of "the worst developments of the general uglifying of Europe."3 Nietzsche has no words too bitter to characterize the movement for economic independence or for female higher education. "A learned woman must have some physiological disorder"-words that recall Sir Almroth Wright's Unexpurgated Case against Women's Suffrage. Only through submissiveness could she become influential; just in so far as she pushed her insurrection would her real power decay. "Man shall be trained for war, and woman for the recreation of the warrior; all else is folly." In a word, the sole importance of women is made to consist, not in anything that they have, or may come to have, of personal worth, but in the effect they produce upon the racial stock. The most arrogant assumptions of a male aristocracy have nowhere else in literature become quite so articulate or quite so defiant.

In this we can already discern the ground for Nietzsche's quarrel with the more orthodox evolutionists. He thought them far too optimistic about the result which Natural Selection could by itself secure. They had assumed that the struggle for

${ }^{1}$ Beyond Good and Evil, $238 . \quad{ }^{2}$ Ibid., 239, $\quad{ }^{3}$ Ibid., 232.

${ }^{4}$ Zarathustra, i. 18. Nietzsche's disgusting defence of prostitution proceeds on the same line. $C f$. the brief summary in Dr. Levy's Revival of Aristocracy, p. 54. 
existence would, at least on the average, preserve the most desirable types; that minute physical advantages would be accumulated and transmitted by heredity, that a nobler form would result from sexual selection of the most beautiful. ${ }^{1}$ They had forgotten that accident serves the cause of the weak, that craftiness may overcome strength, that heredity is the most capricious of forces, that the lowest forms of life are the most prolific, that genius, though the most sublime, is also the most fragile of machines. To Nietzsche it seemed plain that man as a species was not progressing, and that it was just the superior specimens which were the first to perish. The high type was incomparably more complex, involved "a greater sum of co-ordinated elements"; hence it was an easier prey to disintegration, sure to pass under the "mastery of the mediocre." 2 What was the moral ? It was clearly this, that (unconscious selection could not be trusted; was not the simplicity of the Darwinians exposed if one asked whether, as a matter of experience, the more beautiful partners are habitually chosen in marriage? (If decadence was to be checked we must employ purposive selection.)

Another side of Nietzsche's case against evolution has been brought out with clearness by Mr. Ludovici. Our author, he says, looked at the matter thus:

"Given a degenerate, mean, and base environment, and the fittest to survive therein will be the man who is best adapted to degeneracy, meanness, and baseness-therefore the worst kind of man. Given a
1 Will to Power, 684.
${ }^{2}$ loc. cit. 
community of parasites, and it may be that the flattest, the slimiest, and the softest will be the fittest to survive."'1

The old optimism could perhaps be justified if one retained a belief in providential order; one might then suppose that, if the universe were left alone, the laws of development which God had imposed upon it would work by themselves an excellent result. But was not such a faith mere naiveté from the standpoint of mechanical atheism? Nietzsche had not, indeed, abandoned the idea of purpose, but it had ceased for him to be a purpose directed from without; it had become purpose which man must himself devise and execute. ${ }^{2}$ Nihilism had resulted when the old theological goal was seen to be a mirage: it might give place to a healthier confidence if men could realize that they were the creators of their own goal; let them give up their Spencerian folly about passive adaptation to environment, ${ }^{3}$ let them grasp the thought of an inward energy which should bend environment to the aim which man deliberately chose.)

Yet, subject to this emendation, Nietzsche makes large ethical use of the Darwinian formula. He points out that among individuals Nature tends to kill off the sickly, the less fit both in body and in mind; she would preserve the sturdy and robust: these in turn were more likely to beget a race that is physically desirable. What disease and failure did in the life-struggle of individuals, war must do in the

1 Nietzsche: His Life and Works, p. 72. Cf. Mr. Ludovici's Who is to be Master of the World? p. 84 .

2 Will to Power, 20.

${ }^{3}$ Genealogy of Morals, ij. 12. 
conflict of nations. For a people, too, might become effete, anæmic, unworthy of its place; it was dispossessed by a hardier, a more masterful stock, and to complain of the injustice of such things was to be misled by conventional morality. One is reminded here of Bernhardi's notorious aphorism, "The verdict of war is biologically just." The awful doctrine that the battle-field is essential to vigorous life, and that the peaceful régime leads to decadence, is repeatedly avowed both in Zarathustra and in The Will to Power. Nietzsche can even find something to approve in the socialistic welter of European society; it keeps alive the spirit of fight; " it delays " peace on earth ' and the whole process of character-softening of the democratic herding animal."1 "I am delighted," he exclaims, "at the military development of Europe, also at the inner anarchical conditions; the period of quietude and 'Chinadom' which Galliani prophesied for the century is now over." "2 This passage deserves study by those who see in Zarathustra a prophet of peaceful culture as against Bismarckian aggression. Again, he says: "Ye shall love peace as a means to new wars, and the short peace more than the long "; "Ye say it is the good cause which halloweth even war? I say unto you: It is the good war which halloweth every cause."

We are now prepared to look at that strange vision of the ideal which corresponds in Nietzsche's morality to Plato's Republic, More's Utopia, and St. Augustine's City of God. It is one of race efficiency exhibited in a few predominant individuals, and it is to

1 Will to Power, 125.

2 Ibid., 127.

${ }^{3}$ Zarathustra, i. 10.

4 loc. cit. 
be reached by selective competition when we have ceased to load the dice against the best players. Human progress, he argued, had been in some degree thrust upon us, but misguided man, with his perverse valuations, had long been hindering and hampering the forces which would have raised him. Philanthropy had cut athwart the selective work of Nature; ${ }^{1}$ it had taken as its especial care just those who were physically, mentally, economically, the weaker combatants $;^{2}$ it had systematically preserved all that ought to be weeded out. ${ }^{3}$ The only cruelty in Nature was a cruelty which man had forced her to practisecruelty "against her lucky and well-constituted children."4

"Deliberately to thwart the law of selection among species, and their natural means of purging their stock of degenerate members-this, up to my time, had been the greatest of all virtues. ... One should do honour to the fatality which says to the feeble 'perish.' "15

If society could be persuaded to value along the right lines, it would despise the ideals of pleasure, happiness, so-called virtue; these made reference simply to the race of puny weaklings that are here to-day; they neglected to ask whether something so far undreamed of might not yet be made out of man, ${ }^{\circ}$ something which should put all these aspirations to shame. The "f far-off divine event" by which life should be justified was the evolution of a higher

1 Will to Power, 54.

${ }^{2}$ Ibid., $55 \mathrm{ff}$.

${ }^{3}$ Zarathustra, i. 21.

4 Will to Power, 685.

5 Ibid., 54.

6 Beyond Good and Evil, 203. 
order) Nietzsche gives this the appropriate title Uebermensch (Superman) or Beyond-man), to signify that it (should stand in the same superior relation to the human species we have known as that species itself to the lower animal forms.') Its characteristics should be in every way antithetical to those which we have enumerated under the name "decadence.)" (Superman is to be physiologically perfect, strong, self-reliant, self-assertive; he is to be spiritually a passionate lover of life, no dreamer about other worlds, fulfilling himself to the full here and now. In short, he is to be the final expression of culture on every side.

But at least as important as any physical or intellectual distinction stands the moral equipment of the Uebermensch. He must have so absorbed the great transvaluation as to act upon it everywhere with unerring instinct. For him pity and egoism have been set in their true perspective; he has a work to do, a duty to himself as the symbol of a high race, and he must not be

too full o' the milk of human kindness To catch the nearest way.

Sometimes, as a concession to weaker natures, Nietzsche returns to his point that Superman's lapparent harshness is a benevolent spirit in disguise; after all, was it not mercy which would stamp out the maimed combatants in life's struggle) as one shoots a wounded horse on the battle-field ? Was it not a choice between death swift, painless, curative, and

${ }^{1}$ Cf. Zarathustra: Prologue, 3, 4. The term first appears in Goethe's Faust, but Nietzsche has given it a new meaning. 
death long drawn out, racking, hopeless? And was not the benevolence still clearer toward that wretched progeny which might inherit the feebleness of such ancestors? "Higher than love to your neighbour is love to the farthest and future ones "; Nietzsche here very correctly anticipates that a forswearing of all chivalry towards those least able to defend themselves would be uncongenial even to those strong ones amongst us who approximate most closely to the Uebermensch. Hence the digressions, quite alien, as I have shown, to our author's real contempt of pain; hence the sophisms to persuade us that Superman, like Hamlet when he soothes his father's ghost with the blood of the living, is "cruel only to be kind." In any case, Nietzsche is uncompromising in his demand; a part of the higher character, an essential part, is the readiness to inflict suffering. He who shrinks from clearing away the feeble obstacles in his path must give place to those who are made of sterner stuff. Hence that frenzied passage in Zarathustra which speaks of the greatest danger of all as arising, not from the lower elements of the race, but from vacillation born of pitifulness in the higher man himself, and which declares the last and greatest sin to be pity towards the higher man.

In the light of all this, Nietzsche claims that pessimism is not only condemned, it is also explained. He always recognized a keen penetration in Schopenhauer, "the last German who was a European event"; he not only admits, but is prepared to insist, that from Schopenhauer's standpoint the denial of life was an

${ }^{1}$ Zarathustra, i. xvi. 
inevitable result. For that standpoint had involved the assumption that man as we know him is final; if this miserable product was the best that evolution could yield, the whole movement was indeed condemned. The will to live became, beyond question, absurd. Nietzsche everywhere breathes the scorn of that spiritual visitant in Byron's Heaven and Earth, as he speaks of Japhet's pitiable clinging to the interests and joys, the simple loves and petty virtues, of poor mankind.

Go, wretch !-and give

A life like thine to other wretches-live ! ${ }^{1}$

His point is that the human species, despicable in itself, becomes, when seen sub specie oxternitatis, a thing of transfigured worth. "The glory of man is that he is no end, but a means "; humanity is of value for its promise, not for any fulfilment which has been seen as yet. The development beginning with the amœba, and, to the superficial eye, showing only blind mechanism, was to find its justification in the climax to which it might be made to lead.

And in one way a certain grandeur might be bestowed even on the men of the present. The glad acceptance of their place as a link in the chain, the eager renunciation of immediate self-indulgence that they might advance the racial purpose, this was the highest part which it was possible for them to play. "The Superman is the meaning of the earth; let your will say: The Superman shall be the meaning of the

1 Heaven and Earth, Scene III.

${ }^{2}$ Zarathustra: Prologue, 4. 
earth."1 Indeed, without such voluntary co-operation there was no hope that Nature could continue the ascending line.

II.

This doctrine of the Uebermensch is probably the most familiar side of Nietzsche's teaching, but it is far from being the clearest; it has difficulties which can scarcely be unravelled. Did he contemplate the possibility of a new and higher species in the strict biological sense? He has used phrases which point that way-for example, his picture of man as a middle term, with the ape on one side and Uebermensch on the other. ${ }^{2}$ But, again, he speaks of the ideal as having been already actualized in a few historical heroes, though, in apparent forgetfulness of having said so, he doubts in another place whether any Superman has yet appeared. Is Professor Pigou right in his theory that Nietzsche had in mind an inward state, and in his somewhat startling comparison with the Kingdom of God in Christian Theology? There are New Testament passages which speak of the coming order when heaven and earth shall have passed away, and there are passages which indicate rather that purification of soul in the present which makes it possible to say, "The Kingdom of God is within you." "Beyond-man and the Kingdom of God," writes Mr. Pigou, " both mean, in their deepest sense, a state of heart." "The analogy is interesting,

1 Zarathustra: Prologue, 3. 2 loc. cit.

3 "The Ethics of Nietzsche," in International Journal of Ethics, April, 1908. 
but in one respect it seems defective; Christian teaching regards the good for man as consisting in a renewed will, in a certain type of character and purpose, whether or not this disposition succeeds in outward accomplishment of all that it cherishes; in Nietzschean goodness, on the other hand, external achievement seems essential.

But though ambiguous in some of its details, the general idea of Superman is tolerably clear, and upon it I offer the following remarks:

1. The Darwinian formula lends no real countenance to the view that altruism is morally inferior to egoism, or that the stronger are entitled to exploit the weaker. As I shall point out afterwards, Nietzsche does not derive his ideal from the evidence of evolution, but, as he has been persistently attacked and also enthusiastically defended under the rubric of " the survival of the fittest," it is worth while to examine briefly what this biological cant-so common among the ill-informed-really involves.

It is plain that the qualities of sympathy and mercy have not decreased, but have grown in influence as mankind has evolved. The kindly virtues are more widespread, reveal themselves in a greater number of directions, have at their service a more effective social machinery. If these traits of character are inconsistent with the evolution formula, why have they survived? If cosmic forces make the stronger win just by reason of his pushful egoism, why have not men become more and more egoistic, less and less considerate? You cannot in the same breath assert the perfection of a formula and also admit that an important group of facts contradicts your formula. 
Hence a thoroughgoing naturalist must say that Nature has not had free scope, that there has been artificial interference. For example, her selective hand has been stayed by the dissemination of what is called "morality," and by the fostering of what is called " conscience." Thus men have been unnerved, the bold self-seeker has been hindered from having the "courage of his instincts." Granted; but why have we disseminated morality and fostered conscience? The explanation by supposing a crafty priesthood is of no avail; for, in the first place, no fair-minded man believes that all priests are insincere; and, in the second place, the scheme of charity and benevolence which priests inculcate is powerful in minds for which a spiritual threat has no terrors. If we are in thorough earnest with our naturalism, we must find that the underlying motive of mercy is itself a product of evolution at work upon human character. As Polixenes says in the Winter's Tale $:^{1}$

Nature is made better by no mean But Nature makes that mean; so, o'er that art, Which you say adds to Nature, is an art That Nature makes.

Herbert Spencer, who needed no Bernhardi to draw social inferences for him, saw with great clearness the difficulty which is here presented; he was both candid enough and ingenious enough to restate his formula in such a way as would do no violence to the facts. He pointed out that the competition of life proceeds not only among individuals, but among communities; it follows that a quality of character

1 Act IV., Sc. 3. 
which would be a handicap to the individual competing alone, but a strength to the society of which he is a member, is quite likely to be preserved and augmented. Now, it is clear that nothing reinforces a race in its struggle with other races so much as the virtues of mutual helpfulness and mutual supplementing of one another's defects. That people in which there is a habit of sympathy, forbearance, reciprocal aid, will have the superiority which a unified state has over a body of independent and warring individuals. This is especially so when the stage of primitive militarism is past, when the state has become industrial, when qualities of brain and character become more important than a formidable and agile physique. Thus, the growth of kindliness within a community may be explained without departing from the formula of Natural Selection and the Struggle for Life.

But, it may be replied, this disposition has reached $>$ a pitch which far exceeds such racial utility. It has worked to preserve those whom a tribe would be better without, and it has been cherished towards those who do not belong to one's own tribe at all. Has it not in both these ways made for a weakening, not a strengthening, of the society? If pity has arisen thus, ought it not to be discountenanced when it trespasses the limit of its usefulness? There are two answers-one psychological, the other ethicaland both may be given by those who fully believe that morality has been shaped by evolution. As psychologists we point out that an emotional state cannot be restrained within intellectual channels; it cannot be taught to begin just where reason decides that it 
is salutary, and to leave off just where reason sees no further use for it. If it be a condition of a community's survival that its members should be sympathetic to one another's distress, then distress as such will awaken the feeling; you cannot secure that men shall disregard the suffering of those who are tribally useless or that they shall be callous towards a suffering foreigner. The impulse is a spontaneous one; it will not be governed by far-seeing calculation. Further, whatever be the origin of pity, our developed reason affirms that it is a disposition of the utmost value, whether the person we pity belong to a high or to a low racial type, whether he be of kindred or of alien stock. This is what I called in a previous lecture a " moral axiom"; it cannot be proved, neither can it be rationally doubted. Thus, as we leave behind the stage in which moral valuation is an affair of impulse, and reach the stage where it is an activity of reason, we introduce a factor which it is impossible to define in terms of the biological conflict among blind passions.

Thus, even from a thoroughly naturalistic standpoint, the apotheosis of selfishness has no justification. It was as inevitable that man should develop benevolence and compassion as that he should become diligent, industrious, provident. And though the old creed of Callicles in the Gorgias were as true a reading of facts as it is beyond doubt false, this would not point to an ethic of egoism; it would exclude the possibility of ethic in any real sense at all.

2. But to call Nietzsche a "fearless preacher of the evolutionist morality" is to do him far less than justice. This is the phrase of those who know our 
author only from some stray aphorisms of Zarathustra; again and again in his other books he has insisted that the "fittest" - that is, the creature most able to survive-need not be the "best"; he may quite possibly be the worst, for he may be the most perfectly adapted to an ignoble environment. Nor does Nietzsche bid us watch the cosmic forces and then second them with might and main, whatever be the direction-good or bad-in which those forces appear to move. It is true that he comes very close to such a maxim when he speaks of "will to power" as the sole motive by which one can be influenced; it is true that this position logically negates an ethic. of any kind; but it is only fair to recognize in his treatment of evolution the germ of a truer thought. He bids us reinforce the cosmic process, not because such is the actual way of the world, but because, , with limitations, the struggle of Nature makes for a furtherance of the racial type, and because such furtherance is, in his view, the thing which reason pronounces to be supremely valuable. And just in those cases where such blind natural action thwarts the elevating movement, Niétzsche(bids us oppose Nature; he bids us introduce purposive selection, the purpose to be dictated in the light of his ethical end. To put it concretely, if our author values a Napoleon higher than a Florence Nightingale, this is not due to his conviction that the competitive struggle works towards the supremacy of the warrior type rather than towards the supremacy of the philanthropic; it is because he thought it an intuitive truth that such a character as Napoleon's is superior to Florence Nightingale's. If we differ from him, it is not be- 
cause we read evolution in a different sense, but because our intuitive moral conviction gives a deliverance the reverse of his.

3. Again, we must recognize that Superman is a concrete vivid image of some ideals which are of genuine but neglected value. Appreciation is certainly due to our author's plea for eugenism, to his defence of the rights of the unborn. We have been too much disposed to think only of the convenience, the interests, the general well-being of the generation present at the moment, leaving posterity to look after itself. Yet as far back as Plato the principle was laid down that one ought, so far as possible, to include in one's moral effort the production of a higher racial type, the securing of a better, healthier, happier plane of life for those who are to come after. Modern biological and sociological advance has put some instruments into our hands which we may use in this direction, and we must admit that we have not so far lived up to the level of the knowledge that we have reached. The public conscience has been hard to arouse, little note has been taken of the heritage of disease and misery which one age is transmitting to another simply because certain obvious physiological morals are ignored; even so mild a scheme as the segregation of imbeciles has not yet won acceptance. Nietzsche puts the protest and appeal of eugenism in his own picturesque and lurid way. He bids us extend the law of love to include not only the neighbour whom we see, but the unborn millions whom we may either strengthen or handicap for the struggle of life; he denounces the easy-going sensitiveness which shrinks from social surgery. But here, as elsewhere, 
we must point out that the advocate has gone a long way to spoil the case. For he treats the (present generation, at least in its weaker and less capable members, as destitute of intrinsic rights or intrinsic value of any lkind; its whole function becomes that of subservience to a superior order yet to come. $)^{1}$ As Major Darwin has well remarked, sympathy for the race of the future will not be enlisted by anyone who shows himself callous to the race of the present.

4. Finally, we may grant that some of the qualities in Superman which morality does not hesitate to condemn have been in the past of high social advantage. Circumstances occur in which the world profits through the self-seeking and the injustice of an individual. Lecky has pointed out in a well-known passage $^{2}$ that a country often owes more to a man of no scruples, but of great forcefulness and great audacity, than to the retiring, the modest, and the conscientious; that gratitude, while now a winsome virtue, was at one time of less social importance than that spirit of revenge which coerced rude society into order. The same point has been put differently by Professor Simmel, ${ }^{3}$ when he insists that a man should so select his profession as to utilize his moral deficiencies in the public interest. Whether we say, with the theologians, that Providence brings evil out of good, " making the wrath of man to praise Him," or argue with Mandeville that "private vices are

${ }^{1}$ Cf. Will to Power, 866: "That man for whom the turning of mankind into a machine is the first condition of existence, for whom the rest of mankind is but soil on which he can devise his higher mode of existence."

${ }^{2}$ History of European Morals, vol. i., pp. 37, $40 \mathrm{sqq}$.

${ }^{3}$ In International Journal of Ethics, vol. iii., 1892-93, p. 490 sq. 
public benefits,"1 the fact seems to be beyond question.

But there is nothing in this to alter our view that evil is evil though it may by accident be the source of good, or that vice is vice though a special combination of circumstances may make it productive of certain benefits. The external outcome of an act is one thing, the inward character which it reveals is another; and while an isolated act or set of acts may do more good than harm, the disposition that underlies them may be such as to do on the whole much more harm than good. ${ }^{2}$ No doubt it was Napoleon's lust for power which saved France from the anarchy into which she would otherwise have fallen; we may agree with Zarathustra that the country was indebted less to the Emperor's philanthropy than to his selfseeking ambition. But that this quality, when divorced from moral restraint, is, in general, sinister in its consequence, the example of Napoleon himself is a conspicuous illustration.

5. In calling upon man to make himself a " means," a "bridge," a "rope," which shall effect the transition from the lower types of the past to the transcendent type of the future, and in insisting that this (should be man's only aim) the only ennobling value of an otherwise sordid life, Nietzsche has made a singular breach with his own doctrine of self-expression. He had denounced self-sacrifice as a sort of moral imbecility with which the Christian religion had inoculated the healthy pagan blood. And we

1 In his Fable of the Bees.

${ }^{2} C f$. the excellent discussion of this point in Henry Sidgwick's Methods of Ethics, p. 428 f. 
granted so much as this, that he had ground for recalling us to a belief in ourselves, for insisting that self-expression and self-development have a place among the virtues. But he proceeds to demand a > self-immolation more complete and more fanatical than was ever dreamed of by the most demented ascetic. Even Stylites on his pillar had Paradise before him. He could exclaim:

"Courage, St. Simeon! This dull chrysalis Cracks into shining wings."

But there are no "super-terrestrial hopes" for him who has replaced devotion to God with devotion to Superhumanity.

"I love," cries Zarathustra, " those who do not first seek a reason beyond the stars for going down and being sacrifices, but sacrifice themselves to the earth, that the earth of the Superman may hereafter arrive."1

There is an old phrase about making the best of both worlds, but our apostle of self-development here requires an abnegation so perfect that the victim must forego all hope of personal achievement either here or hereafter. Thus, we seem to have a yawning >incoherence at the very heart of Nietzsche's ethical thinking. That disposition which he despises is, at the same time, the essential means to the good which he aims to bring about. The spirit of self-assertiveness which he denounces in the ordinary man and glorifies in the higher man are one and the same trait of character. If it be right for another being to be pitiless towards me in the interest of his selfhood

1 Zarathustra: Prologue, 4. 
which struggles to be developed, how can it be wrong for me to obstruct him to the limit of my power in defence of my selfhood which refuses to be suppressed? Other moral teachers could, no doubt, logically and persuasively appeal for sacrifice of personal aims upon the altar of a sacrea cause; but surely not that prophet who had proclaimed that the only cause really sacred is the pushful efficiency of the stronger?

Nietzsche can escape from this objection only by reiterating that distinction in worthiness among selves which we have seen to be impossible for one committed to the doctrine of will to power. Again and again he tells us that the ideal for one class is not the ideal for another, nor will he admit that the conflicting interests can ever be reconciled. "That which serves the higher class of men for nourishment or refreshment must be almost poison to an entirely different and lower class of human beings. The virtues of the common man would perhaps mean vice and weaknesses in a philosopher." Thus, the autonomous character of the upper rank in no way involves a like freedom for the rest. Zarathustra presses the question: "Art thou one entitled to escape from a yoke?" 1 His own message is directed only to the "mandarins of the spirit" $;^{2}$ they alone are of sufficient value to make release from the law of custom either safe or desirable. Now, if our author had kept to the view that the truth about morality

1 Zarathustra, i. 17.

2 The phrase is Professor Lichtenberger's: Gospel of Superman, p. 39 . 


\section{NIETZSCHE AND MODERN GERMANY}

must be permanently concealed from the mob, and that, as the old political cynic remarked, "the people's only concern with the laws is to obey them," he might have maintained a Macchiavellian consistency. He would still have been open to our criticism in last lecture; he would still have been guilty of an impotent $>$ denial of the moral axioms. But, as if to involve himself in every possible contradiction, he claims that lower man shall gladly acquiesce in his own obliteration. How can this be if the sole motive of which human nature is susceptible is will to power?

This crucial absurdity again and again reappears; one is amazed that along such a line of thinking Nietzsche should have fancied that any real rejoinder to pessimism could be found. When the prophet describes the "last man," who has done nothing better than to "devise happiness," the vulgar herd cry out: "Give us this last man, 0 Zarathustra; make us into these last men! Then will we make thee a present of the Superman,"1_I confess that my own sympathies are with that vulgar herd, though Zarathustra "turned sad and said to his heart: 'They understand me not; I am not the mouth for these ears." "We must, however, protest that we understand him well enough, but we detect in what he says a very simple fallacy. He insists upon evaluing the world as if from the standpoint of some outsider whose property the world is, and who wants to make the best of it, developing here, truncating there, as the end he has set before himself may dictate. $\mathrm{He}$

${ }^{1}$ Zarathustra: Prologue, 5. 
refuses to recognize that the instrument he is asking us to perfect is an instrument constituted of living, sentient persons, that it has no value except as a means to the highest life for such persons, and that it is to such persons that his appeal is addressed. Nothing could more plainly violate his own principle that the purpose for man must be created from within, not accepted from some authority without. ${ }^{1}$ In short, his standpoint is almost that which the older Calvinistic theologians attributed to the Divine Being. They rejoiced in such passages as, "For this cause have I raised thee up, that I might show in thee My power." They looked upon humanity as a more or less vile material upon which the Creator might so operate without regard to its intrinsic claims as to display His own majesty and to realize an arbitrary will. It was this that moved the impious wit of Burns when he wrote:

O Thou, wha in the heavens dost dwell, Wha, as it pleases best Thysel',

Sends ane to heaven and ten to hell,

A' for Thy glory,

And no for ony guid or ill

They've done afore Thee.

Nietzsche's attitude towards Superman is not so very far away from that of Holy Willie or Habakkuk Mucklewrath towards the God whom they worshipped. Mutatis mutandis the same criticism applies to both. I had occasion, some years ago, to write about this, and I may be permitted to reproduce what I then said: 
"Anyone can understand the distinction between that which is a means to an end and that which is an end in itself. A piece of machinery is admirable so long as it does its work well; as soon as it has outlasted its efficiency, or as soon as something else is invented which will do the work better, the old machinery is 'scrapped.' Whether this stage has been reached must be decided from the point of view of the man who owns the machine, and for whose purposes it is employed. The dynamo generates electricity to drive the city trams; and we hope that as we have experience of one type of dynamo after another we shall discover new models which will make it worth while to discard the old ones. An electrical appliance is "something that shall be surpassed '; each appliance in turn 'leads on to the creation of something beyond itself,' and in such surpassing and creating, the energies of many scientists are absorbed. But the whole process of improving upon and casting aside our old mechanical servants is justified by the consideration that the only value these instruments have lies in their power of ministering to the comfort and convenience of those human beings whom science itself exists to serve.

"Surely, however, we are offered the argument from analogy run mad when we are asked to say that humanity ought to be ready and willing to scrap itself in the interest of some sort of creature higher than humanity, whose coming may thus be accelerated. Cui bono?"1

If it be said that this means the adoption of a

${ }^{1}$ Questions of the Day in Philosophy and Psychology, pp. 258, 259. 
selfish attitude, the repudiation of that higher impulse which makes a man ready and willing to devote all that he has and is to a sacred cause, I reply that such phrases are indeed the language of a high morality, they are the language of Christian morality, but they are logically antithetical to the language of Nietzsche. 


\section{LECTURE V}

\section{A R IS T O R A C Y}

"Wном," exclaims Nietzsche, "do I hate most among all the rabble of to-day? The Socialist, who undermines the working man's instincts, who destroys his satisfaction with his insignificant existence, who makes him envious, and teaches him revenge."

This sounds like the explosion of an English Duke, in a specially candid moment, against Mr. Lloyd George or Mr. Ramsay Macdonald. Yet Nietzsche's defence of aristocracy is not a defence of English Toryism; it would not serve as an argument for " the rights of property," and only in a minor degree for the prerogatives of the House of Lords. ${ }^{1}$ There is no part of his teaching which requires to be examined with more care, and perhaps none which displays, amid the inevitable exaggerations and fanaticisms, such subtle power of analysis and penetration.

\section{I.}

An aristocrat, for Nietzsche, is not a man whom the accident of birth has placed in a position of social importance. He must be one, as our author puts

${ }^{1}$ Cf. Will to Power, 942: "The only nobility is that of birth and blood. (I do not refer here to the prefix 'Lord' and 'Almanach de Gotha : this is a parenthesis for donkeys.)" 
it, " for whom the exploitation of mankind will have meaning "; 1 he must be one whose ego is sufficiently massive to be worth the immolation of a multitude. He must be a higher man. An aristocracy is a group of higher men, holding together, united by their common contrast with the herd, but possessing in virtue of their association with one another, in virtue of their caste spirit, qualities which would not belong in the same degree to each in isolation. Thus Nietzsche passes from the standpoint of individualethics to the standpoint of sociology and politics.

In our author's view, the equipment which gives higher man his distinction is not something that he has acquired; it is something which he brought with him into the world, something which he to whom it has been given can never lose, and he from whom it has been withheld can never successfully counterfeit.

One might take this to mean that Nietzsche's "nobility" is constituted by exceptional talent, wherever that talent is found, and that in consequence those whom society now ranks low and those whom it now ranks high may often have to change places under the new scale of valuation. In short, it looks like an " aristocracy of intellect." But, singularly enough, this is a phrase which always roused Nietzsche's anger. "Wherever," he says, "people speak of the aristocracy of intellect, reasons are generally not lacking for concealing something; it is known to be a password among ambitious Jews. Intellect alone does not ennoble; on the contrary, something is

1 Will to Power, 866. 
always needed to ennoble intellect. What, then, is needed ? Blood. . . . The only nobility is that of birth and blood."1 This is not one of our author's inconsistencies; his view of heredity is of the very essence of his thought.

For "intellectual" men he had a very considerable scorn; it comes out especially in the contempt with which he uniformly speaks of a scientist. In one aphorism he brackets together modern virtue, modern intellect, and modern science, as " forms of disease," 2 and he often alludes to the student of Nature as an inferior craftsman, belonging to the class of the mediocre, useful in his way, but very far from the first rank. At times Nietzsche lets himself go with violence, calling Darwin an "intellectual plebeian," using such terms as "Lilliputian" or "presumptuous pigmy." His reason for this is a necessary outcome of his mode of valuing. A scientist, he tells us, is always a reflector, never a creator; he aims to be "objective," to report with fidelity what he finds; scientific merit depends on the thoroughness with which a man overcomes the personal equation, keeps everything of himself out of his results. Only thus can "objectivity" be reached. If the goal is disinterested knowledge, then the seeker after it must welcome whatever Nature presents with " a radiant and impartial hospitality "; in short, he must be a mirror, and one scientist differs from another only in the completeness with which the mirror's face has been polished, so that it will give back unadulterated all that is held up before it.

1 Will to Power, 942.

${ }^{2}$ Ibid., 50.

3 Beyond Good and Evil, 207. 
If anything is legitimately added, this is only by way of "discovering laws"- that is, arranging the data in such a system that they shall be more readily available for reference through being shortly summarized.

Now this, in Nietzsche's view, was an important work, just as it is important that we should have good joiners or good plumbers to make a house more habitable. But to speak of such scientific reporting as if it were man's highest activity, or of those who excel in it as if they were the noblest of their species, was to confound life with the tools of life, to put the menial tradesman in the place of the master whom he serves. The supreme purpose is the perfecting of mankind, the expansion of its power, the accomplishment of its highest values. What assurance have we that objective knowledge is the sole, or is even a reliable, instrument towards this ? Granted that science has enabled us in some degree to subjugate the forces of Nature; so far as it does so it is in place. But it has claimed a higher position than that of means to an end. Under the rubric, "Truth at any price," it has affected to be an end in itself, and this claim Nietzsche will not allow, for he holds that there is a price which humanity is not entitled to pay.

The point is made clear by an interesting comparison of the aim of science with the object of religious worship. He who said of the Divine Being, "Though He slay me, yet will I trust Him," is, for Nietzsche, very similar in attitude to him who erects a standard of objectivity to which one must, at all costs, be faithful. And each is, he thinks, disloyal 
to mankind; each is a " back worldsman," ready to sacrifice earth with all its values to some problematic or mythical beyond. "There is no doubt about it," he declares; " the truthful man-truthful in the extreme and dangerous sense which faith in science supposes-affirms thereby his faith in a world other than that of life, of nature, of history, and from that very moment predicates this 'otherworld.' Well ! What can he do with its contrary, with this world, our world, except to deny it ? 1 Did not such a man resemble in his outlook the passion of the ascetic ? The latter would immolate anything-his child, his natural instincts-to a God whom such offerings pleased; the former was a nihilist of the human values, prepared, if need be, to go on with his scientific negations though they should lead to a paralysis of life and will. Nothing must be withheld from the devouring jaws of "Truth" !

There is a ring of unreality about this. It will be at once objected that truth and falsity are not material to be bought and sold with a keen eye to profit and loss. It will be said that one seeks to know things as they are, not from any expected gain that such knowledge may bring, but from a psychological necessity which cannot believe and disbelieve at will. It would take us too far out of our course to discuss this; but one must point out in defence of Nietzsche's consistency that for him there was no such thing as this disinterested intellectual compulsion. He anticipated in many respects the view that is now called "pragmatism." A belief for him 
was no product of pure thinking, without admixture from a volitional source; indeed, such purity of thought was a chimæra. A philosopher's opinions were at bottom rooted in a non-intellectual soil. The thinker, as Professor Lichtenberger puts it, " is in reality a cunning advocate, pleading the cause of bis prejudices."1 Kant, for example, was first a Christian, and then a builder of such world schemes as would furnish a basis for Christian faith. Current philosophy was "insidious divinity," and current science was a not less insidious justifying of needs other than the religious. Thus, in his paradoxical way, Nietzsche defines truth as " that sort of error without which a certain species of living being cannot exist. The value for life is ultimately decisive.",2 He would have wholly agreed with Mr. Schiller that the foundation truths-such as the Uniformity of Nature-are at bottom postulates, which we must believe if the universe is to be made fit to live in.

Thus, for Nietzsche it was a mistake to think of experience as something made for us, something which we must accept as it comes; it was rather, through and through, made by us, for it was interpreted by us, and the interpretation meant all the difference. The supreme place of the scientist rested on the false assumption that the "given" cannot be affected by the attitude of him who receives it. If this were so, then our highest task would be to clean the surface of our receptive mirror, to remove the

${ }^{1}$ The Gospel of Superman, p. 158. I am much indebted throughout this paragraph to Professor Lichtenberger's masterly exposition.

${ }^{2}$ Will to Power, 493. 
Baconian Idola. But consider, for example, how different is a sociological " fact" when absorbed into the consciousness of a Nietzsche and a Schopenhauer respectively! The economic "truth" that a certain piece of legislation will extinguish a particular class of traders is one thing to the man of universal benevolence; it is quite another to him who sees in the disappearance of that class a step of racial advance. Thus, the first of artists is not he who amasses material; it is he who directs how the material is to be viewed and manipulated. Scientist might strive against and surpass scientist, as the potsherd strives with the potsherds of the earth; but above them all is the creative spirit who stamps values upon what they produce. And if the stamping is done with a single eye to race perfection, an untruth may often have to be valued higher than a truth. There are situations in which the things we most prize can be conserved only through the acceptance of " falsehood." When these occur, "objective reality" must go by the board; if lying is essential to life, then by all means let us have life even through lying. "The falsity of a judgment is not for us an objection to this judgment."1 As a final confirmation of his view that science moves on a low level, Nietzsche points out that scientists have begun to glory in their scepticism; they actually make a distinction out of the impotence of their will; they hold suspense of judgment to be an intellectual feat, though anyone can see that faith in something is a sine qua non of progress, that universal disbelief is the road to

${ }^{1}$ Beyond Good and Evil, i. 4. 
decay. ${ }^{1}$ They are inferior even to the Christians, for these at least have set a goal before them. For himself, he is a humanist first and last.

Hence the aristocrat was not, according to Nietzsche's scale, an "objective man" like the scientist, nor a "productive man" like the poet; he was one whose will called values into life, whose personality made his own values recognized by the weaker personalities with which he came in contact. Highest of all was he whose values were those of man on the supreme level of development, the Uebermensch of last lecture. But such insight was the fruit of no special ingenuity in reasoning; it was an inheritance from generations of men who had ruled; it was the tradition of an upper class. Heredity and blood made all the difference; the higher type had "special conditions of origin." 2 Nietzsche's view seems to have been that just as there are occupational diseases, ailments engendered by particular handicrafts, so a brand of character is fixed upon everyone by the sort of life which his progenitors have lived. "It cannot be effaced from a man's soul what his ancestors have preferably and most constantly done." 3

What, then, concretely, are the characteristic values which a ruling order imprints upon those who belong to it, and which it hands down to its descendants?

1. First among them is a proud self-respect, and a proud self-confidence. Nietzsche draws with great

1 Beyond Good and Evil, 208.

2 Will to Power, 866.

3 Beyond Good and Evil, 264. 
clearness the distinction between pride and vanity. ${ }^{1}$ The source of life for the one is outside, the source of life for the other is within. A vain man lives on the good opinion of somebody else; his self-feeling depends wholly on what others think and say of him. He welcomes praise and writhes under depreciation, whatever be the place from which these come. He subjects himself to them by turns. Thus we often see the monstrous paradox of the man who would arouse in onlookers an approval which he knows to be undeserved, that he may later come to believe in that very approval which he has fraudulently manufactured. In contrast with such a character is that of the proud spirit, assured of its own worth, " able to call its own passions good without the help of a moral formula," 2 following instinct, suspicious of itself only when it is being generally applauded. Pride is most secure, and it is, morally speaking, most fruitful, when one feels himself congenitally isolated from the masses around. Such a man is the very reverse of those who aim, as Spencer puts it, at "adaptation to environment"; it is rather in a hostile environment that the aristocrat reveals his strength; it is there that he shows the virility of his character. In misfortune he is the last to ask for someone else's help, much less for his pity. To sympathize with him is to insult him, for it is to forget that such as he can exploit misfortune itself, can absorb it and rise above it. He will court no man; he will not even condescend to refute a baseless calumny. Nietzsche's account of the aristocrat often

1 Beyond Good and Evil, 261.

2 Will to Power, 916. 
reminds one of Byron's picture of Lara looking on at the dancers, more human than he will allow anyone to think, too contemptuous of the herd to trouble about maintaining among them his good name:

Yet there was softness too in his regard At times, a heart as not by nature hard; But once perceived, his spirit seemed to chide Such weakness as unworthy of its pride, And steel'd itself, as scorning to redeem One doubt from others' half withheld esteem. ${ }^{1}$

2. Again, the aristocrat possesses an abounding energy. He will do many things for his race. "Every elevation of the type "man,", writes Nietzsche, "has hitherto been the work of an aristocratic society, and so it will always be." 2 The reason is twofold. (a) Only through observing from above the distances that separate actual men can the notion of yet higher possibilities be formed; only through this "pathos of distance" could " that other more mysterious pathos have arisen, the longing for an ever-widening distance within the soul itself, the formation of ever higher, rarer, more comprehensive states." 3 This passage alone is enough to show that it is not the aristocrat in the conventional sense that Nietzsche has before him; for that sort of person it will hardly be argued that the self-consciousness of rank need have this psychological result.

(b) The progressive man is necessarily an innovator; he breaks away from custom, he devises his own values, and asserts them fearlessly against convention.

1 Lara, i. 17.

2 Beyond Good and Evil, 257.

${ }^{3}$ loc. cit. 
But no society can allow such deviation from type until it has reached a certain security of strength; it must have become safe from the attack of its neighbours, and it can effect this only through a long period of uniform discipline. As Diocletian says in the Virgin Martyr :

In all grówing empires

Even cruelty is useful; some must suffer And be set up examples to strike terror In others though far off; but when a state

Is raised to her perfection and her bases

Too firm to shrink or yield we may use mercy, And do 't with safety.'

Our author held that strength like this cannot come from the welter of a democratic community; only after an extended rule of aristocrats has consolidated the mass may the experiment be tried of allowing an individual to strike out for himself. The morality of custom is unsuited to high creative types just because it is so perfectly suited to mediocre uniform types.

One may grant all this, but may ask impatiently what heredity and blood have got to do with it. Is $>$ not Nietzsche describing simply a strong original personality? And may not this appear quite as well in one rank as in another? Is it not even more frequent in men who have had to " make their own way" ? We must remember, however, that Nietzsche is dealing with moral values, and that from his standpoint it was psychologically impossible for anyone to take on such matters a disinterested intellectual view. We must value our own type, for our sole impulse is

C. ${ }^{1}$ Massinger, Virgin Martyr, I. i. 
will to power. Hence a man of the people must adopt the people's values; mentally he may be far above them, but emotionally and instinctively he is one of themselves. If we want an innovation upon the code of the herd, we must look for it to those who have been brought up in contemptuous isolation from the herd. Nothing of the sort can come from the tamed, drilled, domesticated creature who has been trained to look upon moral maxims as being "by their very nature universal."

3. Arising from the aristocrat's pride we get two conspicuous virtues, truthfulness and magnanimity. Lying and deceit are the weapons of the weaker, the subordinate class; they are like those methods of treachery by which feeble warriors seek to overcome through guile those whom they dare not meet in the open field. And, though the slave-morality enjoins a man to speak the truth, this veracity is quite different from the veracity of a master. "Shall Cæsar send a lie ?" There you have the voice of the upper order, the spirit which is candid by reason of its dignity. But for the proletariate the censure of lying came from a sordid ingenuity of self-defence; they were afraid of one another. Everyone apprehended that someone else might steal a march upon himself; hence they spread abroad the idea that, under awful religious penalties, every man must make his thoughts and plans transparent to every other. "Thou shalt be recognizable; thou shalt express thy inner nature by means of clear and constant signs, otherwise thou art dangerous."' The aristocrat will carry this frank, open character into both his friendships and his

1 Will to Power, 277. 
enmities; he has not, like the plebeian man, been forced to take "prudence" as his highest virtue. He "lives dangerously," and exults in the risk; no calculator, but straightforward and passionate in his impulses. Hence even his anger leaves no sting. Very commonly he quite forgets a meanness that has been practised upon him; he is too contemptuous to let such a thing obsess his mind. Contrast with this the duplicity and malice of low-class revenge, lurking in the dark for the chance to strike from behind. To such a soul nothing is so congenial as " hidden crannies, tortuous paths, and back doors; everything secret appeals to him as his world, his safety, his balm."1

4. A further mark of high rank is the possession of an instinct for rank, just as a chief sign of our vulgarized Europe is the complete decay of reverence, the feeling that everyone is as good as everyone else, that each may sit in judgment upon all and deliver his opinion upon everything. Men are not born equal; they differ as widely as the members of any other species. He who knows and acknowledges a superior when he meets him attests, not a spirit of cringing, but a nobleness of insight. Herein is a touchstone by which the quality of souls may be judged. In this the peasantry is far more refined than the bourgeoisie. Lowest of all is the "newspaper-reading demi-monde of intellect," the unlovely product of universal suffrage. "Nothing is so repulsive as their lack of shame, the easy insolence of eye and hand with which they touch, taste, and finger everything."2 To correct this it is necessary

1 Genealogy of Morals, i. 10.

2 Beyond Good and Evil, 263. 
to hedge certain things about with an artificial protection. A tyrant authority will in time compel that reverence in the mob which a noble nature would instinctively yield. Nietzsche finds that an important discipline of manners has in this way arisen from the homage that Europe has so long had to pay to the Bible. It is much for the sentiment to have been at last " instilled into the masses that they are not allowed to touch everything, that there are holy experiences before which they must take off their shoes and keep away the unclean hand." But that man has in him something of the aristocrat-whatever his social rank may be-who needs no such external coercions, who "feels the nearness of what is worthiest of respect." 1

5. Finally, the aristocrat assumes as axiomatic that men are of unequal worth, that he and his class are related to the common herd as the precious ore is related to the tons of quartz from which the ore is drawn, and that a multitude is well sacrificed to maintain the quality of a few. This is the real point of that individualism in Nietzsche of which we have been hearing so much. He had no expectation, and less desire, to elevate mankind as a whole; his thought was for a few high personalities. "The general welfare," he writes, "is no ideal, no goal, nothing that can be at all grasped; it is only a nostrum."2 "Humanity must always act so as to evolve men of genius; it has no other task." 3 Nor did he advocate this because he anticipated that from men of genius

1 loc. cit.

2 Beyond Good and Evil, 228.

3 Schopenhauer as Educator, section 6. 
the race would ultimately benefit. This softening suggestion by Professor Lichtenberger ${ }^{1}$ has no genuine support in anything that our author has written, and he has said much that is wholly at variance with it. He insists, indeed, that there must be a "sound and well-constituted mediocrity," of the mediocre, solely for the sake of the elevated few who need such a basis to rest upon. The aristocrat is to owe no obligation save to his equals; if he does not feel like this, he is unfit for his caste. No one could breathe a deeper scorn than Nietzsche's for the weakness that sees in the good of all, or even in the good of the majority, a motive to which consideration should be paid. Speaking of the upper rank, he says:

"Its fundamental belief must be precisely that society is not allowed to exist for its own sake, but only as a foundation and scaffolding, by means of which a select class of beings may be able to elevate themselves to their higher duties, and in general to a higher existence."

\section{And again:}

"At the risk of displeasing innocent ears, I submit that egoism belongs to the essence of a noble soul: I mean the unalterable belief that to such a being as ' we,' other beings must naturally be in subjection, and have to sacrifice themselves."

I should not multiply references upon a point so clear if some recent writers had not attempted,

${ }^{1}$ Cf. Gospel of Superman, p. 171.

${ }^{2}$ Will to Power, 864. Cf. ibid., 892 f.

${ }^{3}$ Beyond Good and Evil, 258.

${ }^{4}$ Ibid., 265. 
against the plain sense of Nietzsche's language, to maintain that he was an erratic but a loyal supporter of the good of all. I venture to say that no "pneumatic" interpreter of Scripture ever had a harder task for his perverse ingenuity.

Such is Nietzsche's view of the two orders of mankind: the one self-reliant, bending circumstance to its will, at home in prosperity, yet able to despise and even to exploit misfortune; open and forgiving towards inferiors, because too haughty to deceive them or to remember their faults; sensitive to rank like an artist to the shades of colour, taking its own caste worth for granted, and acknowledging no debts to a caste below, valuing itself like some precious ore just in proportion to its rarity; the creative and reforming spirit which gives birth to every new ideal of man: the other cringing, parasitic, seeking comfort above all else, subterranean in its hatreds, envious and revengeful towards all that outshines itself, with a lust to break down all natural barriers, fostering the mediocre and crushing the exceptional, fit for nothing but to pace the round of a cast-iron formula. Though he saw the difficulties of making such a claim good, Nietzsche maintained that the first order corresponds, roughly speaking, to those of high social descent, and that the latter corresponds in the same approximate fashion to the proletariate. The separation was not one which had been produced artificially, and which artificial means might overcome. It was not desirable to overcome it; any attempt to do so-for example, through intermarriage-would level down rather than up. And the tragedy of Europe lay just in this: that the modern 
creed of equality hindered us from making the separation still more acute. Agitations, revolutions, wrongheaded systems of thought, mean and grovelling religions, had all contributed, like a fermentation of liquor, to bring the dregs to the top. The slave had begun to masquerade in the diadem, and the master was serving at the tables.

History, as our author is never tired of pointing out, reveals many a conflict, many a clash of opposing systems and opposing ideals, but this was the inner spring behind them all; there was no other so ubiquitous, so pregnant with consequence. It was the struggle between oligarchy and democracy, between the rule of the few that are competent and the rule of the many that are incompetent, between capacity relying on its native worth and stupidity backed by overwhelming numbers. There had been times, in the great pagan age, when the issue was decided aright, when, as it always should be, the race was indeed to the swift, and the battle to the strong. Those were times of progress, when all that was best in the fibre of Europe was knit together; times which had left us a legacy far beyond our deserts, a legacy which we were too pusillanimous to take up. The darkened glass of Christian ways of thinking had obscured for two thousand years the real issue between a high and a low humanity.

He looked at the Greek rólıs resting on a basis of slave labour, at Plato's contempt for the swinish multitude, at Aristotle's omission of all blessings for the poor; he looked at the exploits of the men of action, at the civilizing wars of Alexander, at the Imperialism of Julius Cæsar, at the world-dominion 
of Augustus; he recognized that in all this there was necessarily involved a natural right of the few to command, and a natural necessity of the masses to submit. He turned to the New Testament, and he found there the instrument that had reversed the engines of mankind; for he read that those are especially blessed who are poor in spirit, those who mourn, the meek, the merciful, the peacemakers; he read how God had made foolish the wisdom of the wise; how not many mighty, not many noble, are called; how God had chosen the weak things of the world, the base things, the things that are despised, yea, and things which are not to bring to nought things that are. Finally he found that even wretchedness itself was exalted into a distinction; for were we not taught that the very chastisements of God are a mark of His peculiar love? "Enough! Enough!" he exclaims. "Bad air! Bad air! Methinks this workshop of virtue positively reeks."1

Thus, Christianity lay at the root of the democratic: revolution. A slave had been encouraged to think that his own wretched qualities were intrinsically equal to those of his master. Supernatural dogma had been invented to back up and make plausible an assumption dictated by conceit. He had been told of a God before whom all men were alike, of a soul that had an inherent nobility, whatever might be its lot in the flesh; of a New Jerusalem, where the first should be last and the last first; of the meek and contrite spirit that was an ornament more precious than gold; of a Divine Incarnation in One that was a

${ }^{1}$ Genealogy of Morals, i. 14. 
Man of Sorrows. For a man thus taught to expect a future which should reverse the valuations of the world it was a short and easy step to the conclusion that he might anticipate Providence by reversing them now. If slave qualities were paramount in the eyes of the Judge of all, was it not an act of simple piety for men here and at once to cast down the mighty from their seats, and to exalt the humble and meek? Such a temper of resentment had one weapon to its hand: it could rely on the strength of numbers. And when someone devised the system of government by popular vote, the system in which we ceased to weigh values and began to count heads, the religiosocialistic conspiracy against culture was complete.

\section{II.}

Are there any elements of value in these wild and whirling words? Absurdities lie on the surface, but are there truths which lie below the surface, and which in these days of enthusiasm for equality we have allowed to become obscure?

1. I think we must recognize that there are virtues and vices which belong in a specially intimate way $>$ to high and low social strata respectively. It is difficult to make this clear without appearing to take at times what is called a "snobbish" point of view, but I shall try to put it in quite concrete terms, and I appeal to your experience for corroboration. Consider, for example, (a) the sense of honour, and (b) the sense of public responsibility.

By honour I mean the feeling which makes one shrink from betraying a confidence, incapable of 
taking an unfair advantage, faithful to his word as to his bond, determined to play the game and to keep the game's rules, though he should be a hundred times a loser. It is the finest quality which is developed at a great English Public School. Such names as that of Dr. Arnold, of Rugby, and Dr. Thring, of Uppingham, have become almost national symbols for the type of character I am referring to. There may be no reason to prevent the same sensitiveness of honour from displaying itself in the working class or in the lower middle class; beyond doubt it often is found there. It is absurd to ascribe it wholly to heredity and blood rather than to the moral training which has been given in early youth; but I think it beyond question that the Public School boy has got it in a higher degree than the Boardschool boy, and that he has it because of the social milieu in which he was born and bred. In the field of sport one is less surprised at "fouls" in a match between two clubs of artisans than if the same occurred in a match at Lord's. The refusal to hit below the belt which has come down to us from the knights of chivalry is still the mark of "gentlemen"; the poisoned fang of scandal is the weapon of low-class malice. Thus, a solicitor or doctor who is entrusted with family secrets is as a rule more certain to keep one's confidence inviolate if he is not a man who has pushed his way from a humbler rank of life. ${ }^{1}$ The diplomatic service, where it is necessary to depend so much upon the fidelity of a State agent, is wisely closed to the parvenu, whatever his intellectual adroitness may be. One who has struggled into a

1 I mean, of course, other qualities, moral and intellectual, being assumed the same. 
place to which he was not born, and often just in proportion as his struggle has been severe, has no doubt great qualities, but he has often developed them at the expense of other qualities which men more happily placed by nature have not been tempted to lose. He carries with him the moral scars of the fight; the virtue that is most apt to be injured is just this refinement of honour. It is from such a man that we hear the sinister maxim, "Business is business." Accustomed to fight for his own hand, he comes to think that all is fair in the race for advancement. If the world gave him hard knocks in his youth, he learns to "look out for himself" at the cost of anybody and everybody; if his mental gifts help him to win, he becomes the worshipper of his own unscrupulousness-as Nietzsche would say, he creates his own plebeian values. There is surely still meaning in the phrase " a respectable firm, a firm with an old name." I think that, capacity being supposed equal, we would all rather confide our interests to the financier who had not carved his own fortunes, to the lawyer who had not begun in the rough-andtumble of the village police court, to the merchant who had not once been an office-cleaner. They may have-in many cases they must have-remarkable powers; but too often they have ceased, as Sir John Seeley puts it," "to feel a stain like a wound," to guard in themselves the "chastity of honour." An excellent example of what I mean may be seen upon the stage in Mr. Martin Harvey's striking presentation of The Breed of the Treshams.

Again, if we think of what is called " public spirit,"

1 Borrowing the well-known phrase from Burke. 
the feeling which makes a man so identify himself with his country that her needs and dangers become his personal burden, one cannot fail to see how strongly this is developed in the bearers of an historic family title. The "Vicar of Bray" sentiment has not been that of England's nobility; in stress and strain they have been loyal to what they esteemed the public cause. They have not fought each for his individual hand, however the State might sink or swim. Hence, I believe, one secret of that tenacious hold which the British aristocracy has been able to maintain upon the British nation. There is much in our own past to confirm the view that a governing order develops a tradition of patriotic service in a degree far beyond what the average artisan, much less the average Socialist, is willing to allow. You see it in time of peace, when power of political leadership seems to run from generation to generation in the Cecils and the Cavendishes. If heredity has nothing to do with this, we may well be at a loss to explain it. You see the same thing at times of war in the remarkable proportion of volunteers from the higher social rank. If our nobility makes many an arrogant claim to be considered first in the rosy days of peace, we must remember that when our battles have to be fought they are often the first to fall. I leave this problem to unbending democrats to solve if they can; to me it seems a fact that care for the State as a whole appeals in a specially intimate way to men from that class which has habitually ruled.

One might enumerate other qualities which accompany these, and which too often receive less than justice as we denounce a blasé aristocracy. The 
motto "Noblesse oblige" has still its force, and it covers some qualities which are attractive even beyond their moral worth. Mr. H. W. Garrod has put this in his boyish, paradoxical way when he argues that the morality we value highest in our secret heart may be summed up as that which makes one a "gentleman."1 That King David in the affair of Uriah the Hittite stands revealed as " not a gentleman" is, he thinks, the chief element of repulsiveness in his character. We dislike him, not because he was an adulterer, but because he was an adulterer whose methods were those of a sneak; not because he was a murderer, but because he was a murderer who took advantage of his royal position. One may be permitted to think that the former offence is not as a rule carried out without an element of deceit, and that the latter in most cases involves the use of cowardly weapons. And one may protest that if the moral sense is less offended by the actual adultery than by the scheming which made it possible, less by the actual homicide than by the lie which made that homicide appear an accident, then our consciences need some very vigorous illumination. These features were, no doubt, serious aggravations; we would feel less indignant with David if Uriah had been able to meet him on equal terms-if, for example, the affair had been settled by a duel under recognized duelling rules. But I should still contend against Mr. Garrod that the major element in the king's guilt would remain, and that if anyone thinks otherwise he gives a wholly undue importance to that

${ }^{1} C f$. his essay, entitled "Christian, Greek, or Goth," in The Religion of All Good Men. 
"aristocratic" morality whose due place I have been trying to recognize.

For, after all, the sense of honour and the sense of public responsibility as I have described them belong to the instinctive rather than to the moral plane. Just as courage is largely a physical endowment-exhibited probably at its highest in some carnivorous animals-so these characteristics are in great measure a sort of class etiquette, charming in many ways, but scarcely to be called moral until they are reflected upon and erected into uniform principles. How slightly this is done by the aristocratic mind as such may be seen in the ludicrously inconsistent way with which they are applied. Honour bids one pay his racing debts, though he defrauds his grocer and his tailor; makes him sacrifice his life for the nation on the battle-field, though he remains a willing idle parasite in times of peace; allows him to talk patriotism while he exploits every order but his own; forbids him to cheat a friend at cards, but not to betray the virtue of a friend's wife. It is surely superfluous to insist that the caste feeling of any rank is not in itself a code of duty, though we need not hesitate to admit that each rank as such makes its own instinctive contribution to the data of conscience.

2. Moreover, it is wholesome in days when democracy is taken for granted that someone should remind us of democracy's limits and defects. There is nothing sacrosanct about any particular way of organizing life; all must submit to the test of experience, and we must choose that scheme which proves itself by trial to be most effective in furthering the 
best life. If our ideal be Superman, beyond doubt the concentration of power in the hands of a picked few is the best way to reach it. And, just so far as the production of something like Superman is part of the genuine ideal, democratic methods are open to criticism.

Nietzsche, it seems to me, is right in such points as these: men are not born equal, or anything like equal; some are highly favoured, some are enormously handicapped by heredity, by what biologists call " accidental variation," by difference of local circumstance. A child cannot choose his own parents, his own mental endowment, his own sphere; and these things, so immensely important for his future, are by no means evenly distributed. Nor is it within the power of legislation to redress the balance; the Socialist demand that, though men are not born equal, they should be artificially made equal, recalls the Irishman's view that all the ills he has to endure are owing to the wickedness or the inefficiency of "the Government." For example, economists have long pointed out that we cannot all have the same share in the material goods of life for two simple reasons. The first is, that if you reward alike the capable and the incapable, the industrious and the lazy, you withdraw the chief stimulus to enterprise; and the second is that, in thus attempting to distribute good equally, you would soon reduce the amount of good available for distribution. Moreover, among the things we call good there are some which can be appreciated and enjoyed only by those with a certain capacity, a capacity which does not belong to all; and it seems 
unavoidable, if these privileges are not to be lost altogether, that they should be provided for the few at the expense of the many. The highest Art, the greatest Literature, the things which give to life its most exquisite polish and refinement, cannot, under present conditions, or under any conditions which it is within our power to create, be brought within effective reach of the whole public. For their production it is requisite that a certain class should be provided with leisure, and should be relieved of pecuniary anxieties in a way which would spell economic ruin if one tried to extend it to all. How, for example, can you in my audience to-day defend to yourselves that system under which you are enabled here to spend some of the best years of life in the study of Homer and Virgil, of Goethe and Racine, of Shakespeare and Wordsworth, of music and metaphysics? Someone has to pay for this. In many universities the State pays for a great part of it out of the taxes that are taken from the farmer, the mechanic, the shopkeeper. Can you satisfy yourselves that these persons get either at once or even in the end any real equivalent to themselves for their money? Are they not ministering of their substance to the intellectual luxuries of the few? If so, what becomes of doctrinaire equality?

Now, it does not, I think, follow that everyone must be debarred from such opportunities merely because these opportunities cannot be made universal, or even because the exertions of the larger class must be made in some ways subsidiary to the privileges of the smaller. This has been a casuistical problem of high 
difficulty, ever since the historic day when Pericles offered his defence of Athenian leadership against the indictment of the envoys from Melos. In extreme cases the answer is, of course, easy, such cases as that which Dr. Rashdall's ingenuity has devised when he asks whether the slave system of Egypt can be justified on the ground that " without it the modern globe-trotter would have had to eliminate the Pyramids from his programme."1 But there are many cases in which the solution is far from clear-cases where we must ask ourselves whether a higher good distributed over a smaller area is to be preferred to a lower good distributed over a larger area. And though we are revolted by Nietzsche's claim that the class at the top is the only one which should be considered at all, he has pressed upon us the timely question whether there are not some respects and circumstances in which it should be considered preferentially. That, in practice, we do so consider it is obvious; and if our practice is out of relation to our moral theory, the sooner we are forced to harmonize them the better.

3. Again, without admitting Nietzsche's claim that all progress has been the work of oligarchies, we may grant that democracy has often hindered progress, and we may even acknowledge that in some conditions of life the absolute rule of one is most conducive to the improvement of all. It is interesting to notice how our author had his attention first drawn to this problem. As a schoolboy, Nietzsche was prescribed an essay on Theognis, the aristocratic poet of Megara.

${ }^{1}$ Rashdall, Theory of Good and Evil, vol. i., p. 237. 
Theognis was very far removed from the creed of Russell Lowell that

A poet cannot strive for despotism;

His harp falls shattered; for it still must be

The instinct of great spirits to be free. ${ }^{1}$

The fragments that have come down to us teach a very different moral; he prays that he may " drink the blood of the democrats." " Trample on the people," he cries; "smite them with the keen goad."3

Now, what was the situation in which the poet lived ? The date of Theognis is probably in the first half of the sixth century B.c. Megara had freed herself from the dominion of Corinth; through commercial enterprise and through colonization round the shores of the Black Sea, she was rapidly growing rich. But her wealth was in the hands of a few; the contrast of classes was acute; a huge proletariate was ignorant, famished, murderous. Incessant broils between the organized oligarchy and the democratic mob had brought social order to an impasse. In such an atmosphere and at such a time free institutions were impossible; and many another Greek State was in the same chaotic situation. What actually happened at this period of Hellenism was no doubt the best that could have happened. A succession of individual leaders established personal dictatorship. One strong man, putting himself at the head of the multitude, and winning their hero-worship, concentrated power in his own hands, and dealt out

\footnotetext{
1 Sonnets, XVIII.

${ }^{2}$ Berkgh's Lyric Fragments : Theognidea, p. 314.

3 Ibid., p. 847.
} 


\section{6}

NIETZSCHE AND MODERN GERMANY

the wholesome severity which curbed rapaciousness on each side. While the men called "tyrants" did not scruple to plunder everyone themselves, the change was for the better; the demands of one, however excessive, are more easily sated than those of a group. The masses received a measure of political education; in short, the necessary middle term was interposed between disorder on the one hand and self-government on the other, very much as our own absolute rule in India was a needful step in India's social evolution.

Theognis was one of the oligarchic ring, and Nietzsche saw the situation through his eyes; he saw in it what Burke saw in revolutionary Francean ignorant demos trampling by force of numbers upon the products of culture. But we may follow him so far as this, that government by the people need not be government for the people, that forms of polity are subordinate to the end of all polity, and that a form intrinsically lower may be the sine qua non of progress to higher forms.

These ideas are crystallized by Nietzsche in many a memorable phrase; and if we look upon him as a coiner of aphorism, as a sort of George Bernard Shaw, we must admire his skill, we must place him notably - higher than our own versatile epigrammatist. But I am well aware that the concessions I have made will appear in the light of insults to the Nietzschean devotee. Such an enthusiast as Dr. Levy or Mr. Ludovici would, no doubt, reply that I had eviscerated the great master's message, that I had degraded him to the level which Nietzsche so much despisedthat of a timid and compromising academic moralist- 
that I had acknowledged only a linguistic distinction. I have no desire to suggest that these elements which I think true, though trite, are the real burden of our philosopher's thought about aristocracy. I think that their presence in such artistic form is the secret of the interest which the more cool-headed public has taken in Nietzsche, but that he would himself have denounced such attenuation of his gospel, I do not for a moment doubt. Enough, however, has been said already to dispense me from arguing again the case against class selfishness, nor do I feel called upon to record more than a protest against those ridiculous claims for the paramount influence of blood which every scientific student of heredity will laugh to scorn. Nietzsche denied in explicit terms all that we mean by justice; he defended aristocracy, not as the best thing for all parties or for the larger party, but as best for a small section which has a congenital right to "exploit" the remainder. There is no thought for the claims of Labour, no feeling for the people of the Abyss. It is the naked affirmation of caste, and one is not surprised that he refers approvingly to the Laws of Manu. Such a system was to be sustained by systematic inculcation of a body of belief which those who inculcate it know to be false, but which they find effective for their personal ends. ${ }^{1}$ Our judgment of the whole must be determined by our decision on that issue which a previous lecture set forth-the ultimate issue of belief or disbelief in morality; for him who has adopted the one alternative further discussion is here superfluous, for him who has adopted the other it would be futile.

1 Will to Power, 132. 
That intimate connexion between democracy and the Christian code of morals, of which we have seen our author make so much, I reserve for a later day, on which I shall attempt to bring together the main points in Nietzsche's anti-Christian crusade. It is now time for us to consider the influence which his social ideas have exerted in the society to which they were promulgated. 


\section{LECTURE VI}

\section{NIETZSCHE'S INFLUENCE UPON MODERN GERMANY}

IN this lecture I shall attempt to connect the principles we have been considering with that actual German spirit which has made so much tragic history in the last few months. This is by far my most difficult task. To expound Nietzschean ideas is comparatively easy; to expose their incoherence is not less easy; but to judge the influence of a particular thinker upon a nation's policy is often baffling even when one has spent a lifetime in that nation's atmosphere, and it may be thought quite hopeless when one tries to estimate from outside. We constantly miss the true proportions, lay emphasis in the wrong places, ignore mighty forces that are inarticulate, exaggerate those that are noisy but feeble.

The Saturday Evening Post for November 21, 1914, contains an article by a former Colonial Secretary of the German Empire, in which complaint is made of misunderstanding due to these causes. The writer warns us that three men, Nietzsche, Treitschke, and Bernhardi, are being pilloried by the foreign press as typical spokesmen of German statecraft. He points out that of these the first was a philosopherpoet, justly admired for his artistic workmanship, but anything rather than a man of affairs. The second was a Professor of History, who drew large audiences twenty years ago at the University of 
Berlin, but who did not even found a school, and who owed his popularity in the main to his supreme gifts as an orator. The third is a retired General, with distinct talent both for strategic theory and for semi-philosophical reflection on the sources of war. His views, however, were so extreme that he was removed from his command, and his book, so far from expressing the spirit of Germany as a whole, makes constant complaint about the peace-loving disposition which the masses in that country cherish. The contention is that to accept these three as typical shows either stupid misunderstanding or a wilful attempt to cast odium on an entire race for the peculiarities of a very few.

No doubt at the present juncture it is important that German apologists should disown this trio of writers. Wherever the views of Nietzsche, Treitschke, and Bernhardi become widely known abroad, they are received with a chorus of execration; they make a load too heavy for their country's defenders to bear before the judgment of neutral nations. But we have abundant evidence that they count at home in a far higher degree and in far more practical directions than Dr. Dernburg is willing to allow. Everyone who knows Germany can testify what an idol Nietzsche is to a large and influential class. Only a few years ago I was taken to task by a British critic, very familiar with Continental Philosophy, for using the phrase "Nietzsche revival." "As if," he exclaimed, "there had been a period of temporary obscuration! The fame of Zarathustra has been a light burning year by year with increasing refulgence." "Nietzsche and Wagner," a German 
professor remarked to me some time ago, " are probably the two most talked of men in educated circles." Nor can one admit that public appreciation relates to the form alone; we have often had our own dealers in paradox, whom no one took seriouslywho did not wish to be taken seriously-but whom everyone admired for the sparkle of their epigrammatic wit. Very different is the place of Nietzsche among the Germans; he is widely accepted as what he claimed to be-the great ethical iconoclast who has shattered for ever the Christian values. Nor can we dismiss Treitschke as an isolated or individual voice. He was the historian of the Prussian Government; he has written what is received in Germany as the most discerning interpretation of his country's growth. His spirit is precisely akin to the Cæsarism of his great compatriot Mommsen; it is re-echoed, according to the measure of their literary power, by the national newspapers throughout the country. His influence is sufficiently attested by the judgment of Lord Acton-surely a competent witness, and one whose evidence can have had no bias from the heated feeling amid which we all write to-day. Lord Acton spoke of Treitschke and Sybel as two men " bringing historical teaching into contact with real life, creating a public opinion more powerful than the laws, and entirely remodelling the methods of thought of the generation then springing into manhood." 1

Of Bernhardi I can say less, but the minute accuracy with which he prophesied three years ago the precise grouping of belligerents which has occurred, and his clear foreshadowing of Germany's tactics,

${ }^{1}$ Cf. Lord Acton's Historical Essays, 378. 
have an uncanny suggestiveness of knowledge from inside. It is stated by Professor Jordan, of Leland Stanford University, that this philosophic soldier " had been on a tour round the world, stopping at places where there were Germans, and giving lectures under the official support of the Consuls of the Empire, with the respective Consuls presiding in the chair." Nor am I impressed by the fact that after his book appeared Bernhardi was retired from the active list of the German Army. The two countries were still at peace, and however warmly his views might be approved at Court, such frankness of speech was a blazing indiscretion, by the canons of international etiquette in general, and by the canons of Potsdam policy in particular. Moreover, it would be amusing, if we were not in the presence of such sombre facts, to notice the parallels from Great Britain which Dr. Dernburg asks us to compare with the teaching of Bernhardi. Lord Roberts, he says, has been advising national service; Lord Charles Beresford and Captain Faber have been pressing for an increase in the navy. He protests that he can see no difference between this and the gospel of war for war's sake! And von Mach has referred us to a passage in Mr. Homer Lea's Age of the Saxon-a book, I may point out, not by an Englishman, but by an American-in which it is predicted that the neutrality of small States would be disregarded in a European campaign. I need hardly conjecture to this audience what reception would have been given by the British public to a work like Bernhardi's if anyone in England had had the temerity to produce it. 
At the same time one must recognize that Dr. Dernburg's objection has some considerable point. Much nonsense is being talked about the responsibility of litterateurs for the European war. The public loves to fix odium upon an individual; yet a moment's thought should detect the folly of supposing that Prussia did what she has done because a Professor in Basle and another in Berlin, dead from fourteen to twenty years, incited her to do it. My concern at present is with Nietzsche, and I shall endeavour to guard against the unfairness which Dr. Dernburg suggests. The influence of our author, though great, has been limited; and it is possible even to construct a case for the view that Nietzsche was a deterrent rather than a stimulus to German aggression. Let me take these points in turn.

1. The doctrines of a philosopher are never either intimately known or greatly cared about by the mass of the public. Academic reflection is always more or less esoteric; abstract theories about good, about rights, about the goal of the race, about the ultimate sources of moral valuation, will not greatly affect the man in the street. It is, no doubt, true that interest in such things is more widespread in Germany than in most other countries; it is also true that Nietzsche's way of stating his case is unusually concrete, occupies itself less with speculative abstractions than with the preaching of a new way of life, makes its vivid appeal

- to elemental passions found in every rank of society; at the same time ideas of this order never reach more than a limited vogue, especially when they conflict with morality in that form in which alone the masses can understand it-I mean morality as embodied in 
religion. If the war spirit could transform itself into a cult, it might become, as in Mohammedanism, a sort of public conscience. But no complete hold could be obtained over the mind of the multitude by an ethical propaganda avowedly atheistic. Thus, I am certainly not going to impute reversal of the moral values to a whole nation. That the rank and file of the German people would shrink with disgust from many of the positions of Nietzsche, if they realized what these positions involve, I heartily believe.

Again, it is perhaps needless to say that a system so incoherent as Nietzsche's has made little impression upon Germany's most intellectual men. Many of these, like Professor Rudolph Eucken, of Jena, are among the ethical teachers to whom Europe owes most. In the sphere of religion one often thinks of Germany from the point of view of Browning in his Christmas Eve and Easter Day as the home of a criticism destructive to faith. But no one can doubt that much of our most illuminating exposition of the Christian way of life has come to us in recent years from the countrymen of Friedrich Nietzsche. And even moralists of a type antithetical to Nietzschemen like von Hartmann-have spoken of Zarathustra in tones of contemptuous dismissal which seem to me unduly severe.

2. But the claim has been advanced that, despite all his assaults on accepted morality, Nietzsche's influence has worked against the sinister spirit of racial aggression. This view I am unable to subscribe; I believe that he has been a force of considerable effectiveness in preparing the way for those crimes against civilization which we have seen; and 
I contend that this has been due to no vulgar misunderstanding of what our philosopher meant. That I may be quite fair to an opinion with which I disagree, I shall now set forth as strongly as I can some reasons which may be advanced in its favour.

1. It is urged that Nietzsche was an "individualist," in constant protest against that dominance of the State which is the first principle of Treitschke, and which notoriously pervades the Prussian régime. He has argued that while uniformity of type is a source of strength to the commonwealth, it is also a serious bar to intellectual advance. "Deviating natures are of the utmost importance wherever there is to be progress." 1 He speaks of the man who breaks away from the common routine as one who often "inoculates" the community with something new and valuable, so that strength is reached in the end through partial and temporary weakening. ${ }^{2}$ Thus, he finds the spirit of Nationality, no less than the spirit of Socialism, inimical to outstanding genius, and one might conjecture that he had the Prussian bureaucracy in mind when he wrote of those who " hate and envy prominent self-evolving individuals, who do not willingly allow themselves to be drawn up in rank and file for the purpose of a collective effort." 3

2. Nietzsche makes several direct attacks upon the rising military spirit which seemed to menace German culture, and he has occasional sneers, more or less

1 Human, All-too Human, 224.

${ }^{2}$ Cf. Miscellaneous Opinions and Apophthegms, p. 90; Beyond Good and Evil, 212.

${ }^{3}$ Human, All-too Human, 480. Cf. Rosy Dawn, p. 484. 
thinly veiled, against the system of Bismarck. Germany, he says, was displaying after the FrancoPrussian War clear defects of character; she was organizing herself in the scientific field with a single eye to utilitarian ends, "condemning every individual to a severe helotism." " "The State and civilization are antagonistic; Germany has gained as to the former, but lost as to the latter." The war had been no triumph of culture; it had been won by iron military discipline, natural courage, and endurance. "A great victory is a great danger." High Politics had their drawbacks. Readiness for war was not mainly a matter of money; it involved the withdrawal, year after year, of the " ablest, strongest, and most industrious men in extraordinary numbers from their proper occupations and callings to be turned into soldiers."' If a nation would count as a Great Power, it must " constantly sacrifice a number of its most conspicuous talents upon the Altar of the Fatherland." This meant a public " hecatomb"; the individual could no longer live his own life, and one might well ask whether it pays in the end. ${ }^{3}$ Nor is it difficult to identify the object of Nietzsche's aphorism about the statesman who wants to act quite regardlessly, and masks his malignant purpose under the pretence that he is doing it "for his prince."

3. It is urged that his ideal was not the dominance of any one people, but a cosmopolitan culture, as attested by his favourite phrase, "European men." He insists that the day of separate, hostile nationali-

1 Twilight of the Idols.

${ }^{2}$ Human, All-too Human, 241.

${ }^{3}$ loc. cit. Cf. Thoughts out of Season. 
ties is passing, that it had been preserved mainly in the interest of certain royal dynasties, or of social and commercial classes, but a blending was to be looked for. "We should just fearlessly style ourselves 'good Europeans,' and labour actively for the amalgamation of nations;"1 and he argues that even the despised Jew has his contribution to bring toward the common treasury of culture. ${ }^{2} \mathrm{He}$ repudiates the very name of patriot; the State had become the new idol ${ }^{3}$ there were a thousand and one goals for peoples, but only one goal for humanity; he saw in Germany much to despise, for she had shown little originality, borrowing at every turn from the culture of her neighbours; ${ }^{5}$ Wagner had been carried away by a narrow race spirit; but one must detach one's heart " even from a victorious Fatherland." He thus earned the hatred of Treitschke, who thought him a "bad Prussian," while for the historian at Berlin Nietzsche has only a passing sneer.

This and similar passages must seem a strong cumulative case to anyone who does not know how copiously our author can contradict himself, how easy it is to quote equally definite deliverances on the other side. I shall take the foregoing points in order.

1. That in one sense Nietzsche must have been an individualist is self-evident. So revolutionary a thinker, one so determined, in his own words, "to

${ }^{1}$ Human, All-too Human, 475. Cf. Joyful Science, p. 397.

${ }^{2}$ loc. cit. Cf. Beyond Good and Evil, 250-251.

${ }^{3}$ Zarathustra, i. 11.

${ }^{4}$ Ibid., i. 15.

${ }^{5}$ Will to Power, $92 . \quad C f$. Peoples and Countries, 18.

${ }^{6}$ Beyond Good and Evil, 41 ; of. 58. 
overthrow all the things that men have hitherto reverenced and admired," must claim very extensive freedom from convention. A tutelary State is the negation of such a teacher's existence. One may feel that his defiant attitude towards control sprang in the main from the State's actual association with systems of thought, moral and political, which were different from his own; one may suspect that his individualism would have been less eager if his special point of view had been backed by public authority, that the will to power, which recked so little of the right to life, would not have been balked by scruples about the right to free speech. In matters of thought, however, he was certainly a " herald of revolt." But such licence of speculation is in no way inconsistent with acquiescence in a bureaucratic polity; as Mr.C I Sarolea remarks of the German theologians, "They are very daring when they examine the divinity of Christ, but they are very timid when they examine the divine right of King and Emperor." And that Nietzsche's individualism was worth nothing as a guarantee against national aggressiveness is made evident when - we notice the political opinions which it permitted him to express. He has glorified the great military conquerors; he has laughed to scorn the humanitarian scruples which are troubled by the blood-stains upon such renown. ${ }^{1}$ Two great movements of genuine individualism-the Protestant Reformation and the French Revolution-are the constant butts of his ridicule. ${ }^{2}$ Frederick II. (Hohenstauffen) was, for him,

${ }^{1}$ Cf. esp. Will to Power, 104; Genealogy of Morals, i. 16.

${ }^{2}$ E.g. Genealogy of Morals, i. 16, 17; Will to Power, 94; Beyond Good and Evil, 38. 
the first of Europeans. 1 But in another mood his supreme idol was Napoleon; ${ }^{2}$ France in the seventeenth and eighteenth centuries had been "the last political nobleness in Europe"; it had been submerged beneath the deluge of low-class revenge in 1793, it had been rejuvenated by the splendid despotism of one who was " the incarnation of the noble ideal itself," the man who "had the courage of his worldliness," "in whom the ruling instincts culminated," "to whom we owe almost all the higher hopes of the century." " Napoleon called man, the soldier, and the great struggle for power to life again;" "What a blessing was an absolute ruler for these gregarious Europeans!"8 I do not say that there is no element of truth in such a view, but I do say that it is inconsistent with an individualism which will offer any check to military aggressiveness.

Let us not be misled by a word. The individualism that makes for peace is an emphasizing of the human values, of the sacred right that belongs to every man as such; it speaks of equal consideration for all, and especially for those least able to defend themselves, for the toiling multitude that are such easy victims to a masterful prince intent upon his personal ends. Such an ideal is plainly inspired by

${ }^{1}$ Beyond Good and Evil, 200.

${ }^{2}$ Will to Power, 104. Cf. Peoples and Countries, 18.

${ }^{3}$ Genealogy of Morals, i. 16.

${ }^{4}$ Will to Power, 129.

${ }^{5}$ loc. cit.

- Will to Power, 27.

7 Ibid., 104.

8 Beyond Good and Evil, 199. 
faith in morality, though some of those who show it most are, like Mr. Frederic Harrison, believers in a morality which is humanitarian rather than Christian. But the (ndividualism of Nietzsche was antithetical to it; in his sense of the word it was just the greatest individualists who had been the most ruthless warriors in history) a fact which he himself exultingly proclaimed. There is no ambiguity; he goes straight to the point. (Individuals as such have no value; only high personalities are worth preserving for their own sake.) (The masses " deserve a glance" only in so far as they may be made subsidiary to the great; "for the rest, let them go to the devil and to statistics.") Is it a long step from this to the Prussian officer's description of the rank and file as Kanonenfutter? Not equality, but exploitation, was to be the creed of him who had outgrown the Christian myths. But I ought to apologize for arguing at such length a point so clear. If those critics are right who see in the aspirations of William II. a desire to reproduce the Napoleonic régime, one may sperhaps see in Nietzsche's books some nourishment by which such a spirit was fed.

2. When Nietzsche speaks of militarism as antagonistic to civilization, we must remember that for " civilization" he had no great respect. His ideal was one of culture, and in a notable paragraph he has made it plain that he thought these two objects were far from identical-nay, that they were opposed. Civilization rested on morality, but the great cultural epochs had been periods of "corruption," periods which had broken loose from the " taming "process by which man had been "domesti- 
cated."1 The passages in which he attacks the régime of drill may be paralleled by many others in which the career of the soldier is idealized; he definitely avows his delight that Europe is being turned into a camp. But perhaps the most arresting thing he has said on the matter is in Section 17 of the Genealogy of Morals. He had been dwelling on his favourite subject of Napoleon's glorious re-establishment of oligarchy against " resentment's lying war-cry of the prerogative of the most." He wonders if the like may happen again:

"Was that greatest of all antitheses of ideals thereby relegated ad acta for all time? Or only postponed, postponed for a long time? May there not take place at some time or other a much more awful, much more carefully prepared flaring up of the old conflagration? Further! Should not one wish that consummation with all one's strength ?-will it one's self ?- demand it one's self ?"

3. It is true that Nietzsche (denounced race hatred) that he looked for a cosmopolitan blending of nations, But it is also true, as I shall indicate more fully later on, that he expected this blending to be under the leadership of a dominant " exploiting" class) (He had no high opinion of the Germans; he did not think that the title to the world's leadership belonged to any racial stock as such. And it is a circumstance worth noting that this disregard of every nation's equal right to live, equal right to preserve its own characteristics, and to develop in its own way, is one

${ }^{1} C f$. Will to Power, 896, where the impulses which Nietzsche brands as decadent are declared "fundamental to all civilized society." 
of the things which we lay to the charge of Prussian Junkerdom. It was no cosmopolitanism in the old Stoic sense which inspired Nietzsche's impartial review of European cultures. A man does not become a lover of all mankind simply by ceasing to be a patriot. The philosopher of "will to power" was prepared to applaud dominance wherever he saw a people strong enough to exercise it) the one thing he could not bear was a comity of peoples resting on the principle of live and let live. ${ }^{1}$ Again and again he insists that the day of small communities is past, that it is time to think imperially. One thing he rejoiced to think of as accomplished by the war of 1870; it had "brought into a critical condition the pitiable European petty-State system;" sometimes he saw the root of permanence in Russia, and he admired Russia for just those qualities which fill some of us to-day with misgiving. There at least one was saved from "Parliamentary imbecility, together with the obligation of everyone to read his

1 It is important to notice Nietzsche's description of European States as "anarchic": he means that there is no strong central authority which stands to the individual State in the relation of Government to the individual person; he has in mind Napoleon's idea of a unified Europe. For Napoleon the centre was to be Paris, with rows of palaces for the subject kings and even one for the Pope; for Nietzsche the headquarters might, apparently, be anywhere, so long as the co-ordinate rank of petty Powers gave place to a new imperium Romanum. Dr. Oscar Levy has precisely grasped his master's thought when he writes: "This State anarchy was styled the Balance of the Powers, and consisted in that condition of feebleness and vacillation and lordlessness that thenceforth forbade to any people a Roman sovereignty " (Revival of Aristocracy, p. 2).

${ }^{2}$ Cf. Genealogy of Morals, i. 17; Will to Power, 862 ; Peoples $\checkmark$ and Countries, 18. 
newspaper at breakfast."1 "The time for petty politics is past; the next century will bring the struggle for the dominion of the world, the compulsion to great politics." 2 It is not difficult to detect here the same spirit which has despised the nationality of Belgium and Luxemburg; if anything could increase the shame of such an estimate, it is the thought that he who made it should have affected to be a fellowcountryman of Kosciusko.

One might quote much more from Nietzsche pointing in the same direction: his view, for example, that there is no altruism between State and State; that bordering kingdoms are necessarily hostile, because they, unlike individuals, " have the courage of their own desires;" that a community is in its essence "will to war, to power, to conquest, and revenge;" that militarism is " the last means of adhering to the great tradition of the past, or, when it has been lost, of reviving it;" that "when the instincts of a society ultimately make it give up war and renounce conquest, it is decadent; it is ripe for democracy and the rule of shopkeepers." But I think I have adduced enough evidence to dispose of the theory that Nietzsche, despite the disguise of his language, was at heart a friend of the peaceful, generous, cosmopolitan movement in public affairs. We must read what he has said in that spirit under the light of what he has said elsewhere in a spirit very different. Not every part of a thinker's message is equally influential; part may appeal to the mood of the hour and be followed, part may antagonize the Zeitgeist and be ignored. If Nietzsche had left a coherent system he would not,

' 1 Beyond Good and Evil, 208; cf. Peoples and Countries, 17.

${ }^{2}$ loc. cit. 


\section{NIETZSCHE AND MODERN GERMANY}

of course, be responsible for those who rent his mantle, who claimed the right to pick and choose among his directions. But in this case it is our prophet who has rent his own mantle. No one pretends that his teaching forms a consistent whole; it has even been argued that this makes it all the richer, or that the inevitableness of such contradictions is proof that the science of society is a hopeless tangle. Be it so; a nation which has got to act upon one system, though it may carry on intellectual gymnastics with many in turn, may well choose the course that is congenial, and may fairly claim the sanction of an erratic leader who has advised this course in his predominant mood.

But I am still very far understating my argument. -We set out to inquire whether Nietzsche stimulated German aggressiveness towards other countries, and it would be childish to decide simply by the test of his definite political statements. It is not mainly by what he directly enjoins that a teacher makes his ideas operate upon the life of his audience; he effects far more in indirect fashion, through the moral and social outlook which he introduces, through what Nietzsche himself would have called the "values" which he makes current. That the German values of to-day are such as lead straight to wars of aggression, few persons outside Germany and Austria need any longer to be convinced. How far did Nietzsche help to coin them ? Or, rather, how far did he help to stereotype them? I shall try to give the answer under three divisions. 
His " Immoralism" lent philosophical sanction to the selfishness and the unscrupulousness which had made his country successful in the past.

Let us glance for a moment at political history. Will to power was the principle which had informed Prussian methods ever since Prussia was a kingdom; it is hardly too much to say that no thought either of treaty obligation or of the manifest rights of smaller States-no thought whatever, except that of inability to insist, had ever been allowed to block the schemes of Prussian ambition. The historian records no public immorality grosser than that by which Frederick the Great first extended his realm. He precipitated a war without the shadow of a claim, either in law or in equity, to the annexation of Silesia. He had himself agreed to that instrument which he outraged before Charles VI. was cold in his grave. That he might aggrandize his own State he involved Europe in a conflict curiously suggestive even in its minuter details of that which we now see.

"On the head of Frederick," writes Macaulay, " is all the blood which was shed in a war which raged during many years and in every quarter of the globethe blood of the column of Fontenoy, the blood of the mountaineers who were slaughtered at Colloden. The evils which were produced by his wickedness were felt in lands where the name of Prussia was unknown; and in order that he might rob a neighbour whom he had promised to defend, black men 
fought on the coast of Coromandel, and red men scalped each other by the Great Lakes of North America."1

This, of course, is now ancient history, and the record of other empires is far from clean. One may doubt if any other empire has been so consistently selfish as Prussia; but there at least there have been no regrets and there has been no shame. Frederick the Great is still the hero-_" my sainted ancestor," as the Crown Prince calls him. When Bismarck gave Treitschke access to the public archives, it was with the cynical comment, "You, at all events, will not be shocked to find that our political linen is not as white as it might be." Almost within living memory the wresting of Hanover from her legitimate rulers, and the annexation of Schleswig-Holstein, justify Bebel's remark, "The Hohenzollern never change." But the States of Southern Germany had not Prussia's record; Saxony and Baden had nourished a different human type from the rude soldiers of Brandenburg and Pomerania. When the union was formed, the greatest issue for the peace of Europe was this: Would the ideal of the north or that of the south prevail? Which partner would assimilate the other into its own likeness? We now know the answer, and, despite his verbal repudiations, the whole trend of Nietzsche's influence helped to make that answer what it has historically been. Is it surprising that a people which had won its way by international brigandage should acclaim the man who told them that courage in the field will redeem any

1 Essay on Frederick the Great. 
injustice, and that a good war will sanctify any cause?

Zarathustra was published in 1892, and the circumstances of the moment were propitious to the new creed of will to power. On one side there was a people intoxicated by success; like Byron, Germany awoke one morning and found herself famous. But the man who had made her famous had just been dismissed from office by a young monarch who was determined to be his own Chancellor. There was enough chivalry in the German mind to revert in thought at such an hour to the achievements of Bismarck. He had raised his country from insignificance to the primacy of Central Europe; in a single decade he had organized three campaigns; the first had added the Duchies to the kingdom of William, the second had disposed for ever of Austrian rivalry upon the field of Sadowa, the third had attained the crowning glory of Sedan. On the basis of these exploits the Federation had been welded together; he who was once lord of a barren heritage had been proclaimed Emperor of all Germany with dramatic pomp in the Palace of Versailles. Moab was his washpot, over Edom he had cast his shoe. Everyone felt that all this was the product far less of the sword of Moltke than of the brain of Bismarck. It was the fallen Chancellor who had twenty years before created almost out of nothing the dominance of Prussia for generations to come.

As the statecraft by which he had done this became more clearly realized, it was seen to rest on the principle that the end of national strength justifies every means, however dishonest and however blood-stained, 
by which such strength may be secured. It was his own acknowledgment that, but for him, three wars would not have been fought, and eighty thousand men would not have been slaughtered. His countrymen came to know that it was his ambition which had launched a million German and Austrian troops upon defenceless Denmark-that it was his calculated faithlessness which had deprived Austria of her share in the plunder; it was he who set himself to provoke a conflict with his ally of a few months before, and who emerged from it bearing with him the spoils of Hanover; it was he who falsified the royal telegram which precipitated the war with France. But the man and his exploits sanctified every method; and he had himself proclaimed his method in that grim summary which lived ever after in the German imagination: "Not by Parliamentary speeches or majority votes will these great problems be settled; they will be solved by blood and iron."

During the years that followed, Bismarck had been tireless in impressing upon his countrymen that the weapon he had forged must not be allowed to rustthat the sword must keep what the sword had won. Within six years from the victory of Sedan, his colleague Moltke had declared at a public banquet that France must be fought another time, and the sooner the better. At home two dangers were looming large- - the danger from the Roman priest, and the danger from the red flag of Socialism. The war had incidentally destroyed the temporal power of the Pope, and the Vatican could not look with satisfaction on a complete mastery by Lutheran Prussia over the Catholic population of Southern Germany. 
To crush the ecclesiastics who threatened to nourish local patriotism in the States, Bismarck began his so-called Kulturkampf, imprisoning, fining, superseding priests and bishops wherever he thought them dangerous. It was a disastrous campaign, illustrating once more the old adage that "The Church is an anvil which has broken many a hammer." In a few years he made his peace with the prelates whom he could not subdue, that he might use their help against a common foe. He would allow free speech to the clergy if they would join him in refusing free speech to the Socialists. For the pamphlets of Karl Marx and Lassalle, proclaiming the brotherhood of workers all over the world, indicating as the only struggle worth while that class conflict between the masters who exploit and the workers who are exploited, calling for a halt in armaments and a reduction of military service-these had begun to circulate by the thousand among the men on whom Prussia depended for recruits. The materialistic basis on which Marx rested seemed to the astute Chancellor to provide a unique opportunity for enlisting on his side the forces of that Church whose mettle he had learned to respect.

Now, you will remember that when Nietzsche has exhausted his rhetoric against priests, he heats it seven times against Socialists. The creed of another world and the creed of equality are the twin objects of his scorn, just as they were the twin perils of Bismarckian Imperialism.

On contempt for all spiritual values, and on the iron subjection of every class under military leadership, Germany must rely if she was to maintain the 
tradition of the great Chancellor. Such a régime may well have been distasteful to the masses, but it was the thing that the bureaucrats of Berlin demanded, and a generation of discipline has wrought it into the fibre of the public. The docility of the Social Democrats to-day, their ready subservience to the man in uniform, shows how thoroughly the work has been done. One need not conjecture to what degree Nietzsche's influence was potent against the restraints of religion on the one hand, and against the protest of the industrial workers on the other. His message may well have been a symptom quite as much as a cause of the militarist movement which has cursed Europe for thirty years. But there is little doubt that his popularity is due in great measure to the daring with which he crystallized into artistic aphorism the immoral principles of Prussia's ruling class. His power has not been exercised over the masses that he despised, nor over the academic philosophers at whom he railed; but it has been potent in a circle which wields a far more decisive influence over public affairs. A huge proportion of the German middle class passes through the closely associated training of the University and the military corps; it is here that the strongest public opinion is nurtured, and it is here that Nietzsche has been acclaimed a prophet. He has been the herald of a new order to the German student and to the German army cadet. They are not so stupid as not to see that with all his scolding he is their spiritual kinsman. To the eager, hot youth of the country he has translated into philosophical terms the story of the Fatherland's past; he has fired the imagination with a creed which sees only 
two possibilities, Weltmacht oder Niedergang. What the statesmen of Berlin had for generations been whispering into one another's ears in secret Nietzsche has proclaimed upon the housetops; he inspired the thought that the unscrupulous selfishness which Prussia had plainly practised, and the ruthlessness which had marked the campaigns of her troops, were not something to be ashamed of, but something to be gloried in; he cast the halo of an intellectual vindication round the methods of aggression which the bureaucracy had followed, but which they had formerly thought it desirable to mask before the public opinion of Europe. ${ }^{1}$

\section{II.}

Again, Nietzsche propagated the view that societies as well as individuals are either high or low in the scale of "culture," and that an upper rank has not only a right but a duty to "exploit" a lower.

Such a claim, in one shape or other, lies at the back of most official apologies for German statecraft to-day. Its form has changed; what was once avowed as the right of brute force is now defended as the right of superior mental gifts and superior social organization. Prussia, with weaker nations on her

1 His defenders urge in reply that Nietzsche despised the German Reich, and hated the teaching of Treitschke ( $c f$. Ecce Homo, pp. 123, 124). This is true, but beside the point. I am speaking, not of what he explicitly said about Prussia, but of the politic $\mathrm{ul}$ conclusions which his "Neue Moral" manifestly supports; and pace those who have specialized on Treitschke, the literary culprits in this war are not of one school alone. 
border, used to conquer them on the naked principle that if you have better drilled troops, more effective artillery than your neighbour, you are justified in seizing his land. What we are now told is that if you are culturally higher, if you have better education, deeper insight into science and philosophy, more delicate refinement in literature and art, it is not merely legitimate- -it is a debt to civilization that you should extend the influence of all this at the point of the sword. A " larger place in the sun" is the right of those who can so much more brilliantly reflect the sun's rays. What the militant Moslem conceives as his duty to the faith of Allah, the militant German conceives as his duty to the higher thought. The Panhellenism of Alexander which studded the earth with Alexandrias planted in blood, has reappeared as the Pan-Teutonism of the Kaiser's intimate circle.

Read any pamphlet which states the anti-British case, hear any German spokesman, from the ninetythree professors down to the inflammatory patriots who control the newspapers of Berlin; whatever preliminary argument is employed for the benefit of those to whom the main argument would not appeal, the inference from past exploits is sooner or later advanced. Running through it all you have the thought that Germany's cultural achievements designate her for that inheritance of the earth which the harsher Puritans claimed as a monopoly of the saints. Like Cyrus, when he took the big coat from the little boy and put it on the big boy, they would distribute to us all, not what belongs to us, but what in their opinion fits us. Only the other day we had a half-insane deliverance from Professor Adolph Lasson 
of the University of Berlin. The German race, he says, has proved itself both in the field of intellect and in the field of morals, great beyond the possibility of challenge from any other in the habitable globe; and he concludes with the usual assurance that to a people so wise and so good the justice of God must award victory in battle. Nietzsche's thought is not far off-the thought of mankind as reaching its perfect expression in a select few, though our philosopher would have been amazed to learn that the primacy in culture had settled upon the Germans.

For, while Nietzsche's paradise was the exploiting dominance of Superman, he never entertained the idea that Superman would arise in Junkerdom. His books supply no nutriment for the national vanity; against no race, except the English, has he launched such invectives as against the people among whom he lived. This is one of the reasons which has made those critics who can see only the letter of his teaching acquit him of all responsibility for Prussian militarism. One of the cultures towards which Germany has shown herself most ruthless is that of Poland; yet it was Nietzsche's most passionate protest about himself that he was no German, but a Pole. To prove this he ransacked the records of his ancestry; to confirm it he modelled his manner, let his moustache grow wild, even altered the spelling of his name after the fashion of the country which he admired. With the Germans he would never identify himself; he saw in them just those low qualities against which his polemics were directed. He was daring enough in the days which immediately followed the FrancoPrussian War to tell the victors that they had much 
to learn from the culture of that nation over which they had triumphed in the field. They were beerridden and priest-ridden; they maintained a soil in which genius could scarcely get itself acknowledged; they were inartistic, vulgar, commonplace. How far this explains the neglect with which Nietzsche's earlier books were received I shall not guess; I merely note the coincidence that so long as he emphasized the German failings he was ignored; it was not until he enforced the same lesson in more impersonal terms that, as Mr. Mencken puts it, he was hailed as " a new Luther speaking with the tongue of a new Goethe."

At the same time, Germany has perhaps been logical in applying to Nietzsche's own friends in Poland the moral which was sanctioned by Nietzsche himself. In her judgment, the Polish culture was inferior to the Teutonic; and when Bismarck carried out his huge scheme of colonization in the small neighbouring State, he no doubt argued to himself, like Cromwell when he sent Scotch planters to the North of Ireland, that he was acting in the best interest of the barbarous natives. A quasi-conscience can generally be suborned by statesmen to defend any policy; not the least remarkable evidence of the extent to which one's moral sense may be hypnotized by race feeling is shown by the attitude to-day of the German university professors. ${ }^{2}$ When they argue that their country is on the defensive, that the menace of Russia

1 "The Mailed Fist and its Prophet," in Atlantic Monthly, November, 1914.

${ }^{2}$ One recalls the prescient remark of Frederick the Great: "If we just occupy Silesia quietly, we shall very soon have our bookworm to demonstrate the paper justice of our claim." $C f$. the present war literature by German professors passim. 
on the one hand and France on the other left her no option, that their Foreign Office strove for peace until it was clear that peace could no longer be kept, we may admire their patriotism though we are astonished at their judgment. And I for one feel no impatience when they charge England with race bitterness or commercial greed, though I know this to be groundless and unfair. We cannot expect a dispassionate view in times like these. But where they speak of "treachery to culture," of " reinforcing Muscovite barbarism against German civilization," the voice is not that of amiable bias-it is the sinister logic of Nietzsche's "Neue Moral." And we reply that Russia shall have nothing less than equal justice though she be culturally backward, and that, whatever be her cultural achievements, Germany shall have nothing more.

There is, of course, one sense in which the claim of a nation to hold what seems fairly to belong to her must at times be challenged. A Government may become so immoral as to justify interference. A case may thus be made out for our own conquest of India, and it has seemed to many of us that the unspeakable régime of the Turks has long called for a firm hand from outside. We may freely admit that there have been days in Russia's melancholy past when the intervention of her Teutonic neighbour might have been a charitable crusade. But not even a German apologist will assert any such purpose now, and there are the most encouraging omens that Russia is awakening to a brighter day. Beyond doubt she will work out her future best through internal evolution. What Germany is really fighting for is to perpetuate 


\section{6}

\section{NIETZSCHE AND MODERN GERMANY}

and extend the Teutonic aggression which Austria began six years ago, and of which her royal house reaped the fruit in the crime of Serajevo. And when she has nothing better to say in her defence than that her education, her commercial enterprise, her national management, are more enlightened than that of the Serbs, can she wonder that the world which still believes in moral values has turned a deaf ear? Nietzsche himself has spoken of the days when the Germans still spoke of right and wrong, and had not yet been transformed into Realpolitiker. ${ }^{1}$ It is in the categories of right and wrong that they must speak to-day if they wish to enlist the sympathy of the Americans, who fortunately have not undergone this ethical transformation.

Moreover, those who think that one form of culture $>$ has a moral right to hold another in subjection must rest their view either upon intrinsic superiority or upon intrinsic strength. Nietzsche seems to have combined these arguments, by assuming that high culture accompanies centralized power, or at least that without such centralized power civilization cannot attain to its best. $)$ It is a creed palatable to the German spirit, yet no social dogma is more plainly false. The high cultural achievements of small nations lend countenance rather to the doubt whether citizenship in a huge empire has not a depressing effect upon individual genius. Lord Bryce has recently quoted the cases of Judæa, Greece, the Italian Republics, Switzerland, Scandinavia; each of these was a sphere for the parochial politics which

1 Beyond Good and Evil, 11.

1) ${ }^{2}$ Cf. Peoples and Countries, 18. 
Nietzsche despised; but from each in turn have arisen great creative impulses in religion, in poetry, in art, in science, in social development; it is a poor theory indeed of cultural progress which can find no room for the land of Isaiah, of Plato, of Dante, of Zwingli, or of Linnæus. And if we think of the contributions which colossal empires have made to the world's thought, we very often find that the men who made them belong to a period when their country was in the stress and strain of a conflict against odds; too commonly an assured dominance has been followed by intellectual stagnation. It was an insignificant Germany that gave birth to Goethe, Schiller, and Hegel; it was a nascent Prussia which produced Immanuel Kant. And, whatever they may pretend to the contrary, it is all too plain that the pride of Germany's ruling caste concerns itself less with figures such as these than with the successful devisers of bloodshed. The Kaiser has called Count Zeppelin the greatest German of the century; but it has been noted that his many ceremonial speeches at Königsberg have not contained one reference to the man who shed on Königsberg its deathless renown.

One wonders that Germany has been so slow to draw the moral from the manifest failure of her experiments in centralization; she has assumed that to absorb a new territory it is sufficient to station an adequate garrison, and to substitute by statute her own language, education, and laws. The result is seen to-day in Prussian Poland, in Hanover, in Schleswig-Holstein, in Alsace-Lorraine. The newspapers tell us that in the sanguine circles of Berlin the future of Belgium is being already discussed, and 
that an influential party is opposed to complete annexation, on the ground that yet another discontented province would thus be added to their empire. The problem is one which, so far as we can see, von Jagow and von Bethmann-Hollweg will be relieved from the responsibility of solving; but so far Bismarck's successors have shown none of his shrewd misgivings about the value of a province that is held down by force. The contrast here between German methods and British is very striking. Great Britain has abandoned the attempt to impose a uniform type; she has fostered the individuality of many races; she has seen that as there are different vegetations in different latitudes, so what is best in a nation can disclose itself only through the organs of nationality. Hence the spectacle of enthusiastic loyalty in the common cause throughout the length and breadth of our Empire to-day; hence the Sikhs and Ghurkas fighting shoulder to shoulder with the Black Watch, the Cheshires, and the Canadian volunteers. Hence the new-born patriotism, so astounding to a Prussian, in the commandoes of General Botha. Hence, if you will forgive a personal opinion on a matter of much controversy-hence the sanguine hopes of some of us that great things for the Empire will be achieved in the new Ireland.

\section{III.}

Further, Nietzsche has given enthusiastic support to the view that war is an indispensable agent in racial advance.

We have seen somevacillation in his defence of this; 
so far from suppressing or minimizing what he has said in a contrary spirit, I have set it out in detail. But you will observe that the drawbacks which he has indicated in war belong, morally speaking, to that lower level on which the minds of a large public could be but slightly moved. When the blood-lust is up, appeals for the safeguarding of culture become shadowy and anæmic; let anyone contrast Nietzsche's half-hearted protest with the thrilling denunciations of John Bright. Moreover, in passage after passage our author has stultified all his words of peace elsewhere $;^{1}$ he has definitely sided with those who see in war, not a last resort, but a thing desirable for its own ghastly sake-desirable, also, just because it helps to destroy those moral values which an Englishman would fain preserve. We seem to hear again the message of Will to Power at the opening of that book in which General Bernhardi so outraged the conscience of Christendom. Very different as the two writers are, the common sanction of a gospel of blood is an index of the spirit of their country.

Verbal repudiation is, of course, forthcoming from high quarters. I shall not try to read the psychological riddle of the Kaiser's mind; we are told that the military enthusiasts round him have coined the nickname "William the Peaceful"; but we cannot

${ }^{1}$ Cf., e.g., Will to Power, 167: "Christianity is an ingenuous attempt at bringing about a Buddhistic movement in favour of peace, sprung from the very heart of the resenting masses." And ibid., 923: "The rest of mankind, all those whose instincts are not warlike, desire peace, concord, freedom, equal rights: these things are but names and steps for one and the same thing. ... They would fain create circumstances in which war is no longer necessary." 
forget his close friendship with Abdul Hamid, or his order to the troops leaving for active service in China that prisoners should not be taken. We know by whose influence duelling has been perpetuated in the German universities, and we know the ground that has been assigned. The strategic railway to the Belgian frontier was constructed under the imperial sanction, and the world is now aware of its purpose. I leave you to conjecture how bellicose that group must be in which William II. is the apostle of peace. But he loves to conceive himself as the Lord's Anointed, and though we are not surprised to learn that his theological taste is for the Old Testament rather than the New, we can understand that his favourite rôle cannot be played without occasional lapse into phrases that have colourable likeness to Christianity. Thus, we find him speaking of enemies that have hemmed him in on every side, and of the sword as having been forced into his hand. We even hear of a sacred cause which the Most High has entrusted to his keeping, and which he must defend at any cost. These are words; personally I prefer the blunt, straightforward position of Germany's leading journalist, Maximilian Harden; and the damning evidence of the State Papers is there to show that it was our diplomatists who strove to the eleventh hour, and past the eleventh hour, for peace, and that it was the diplomatists on the other side who had resolved that peace should be made impossible.

Must not such an attitude, endorsed as it is in explicit terms by the leaders of German opinion, have been due in some degree to that minimizing of war's evils and to that absurd fabrication of its blessings 
which Nietzsche and others like him have made current coin in their country's thought? We know how they talk. War as a biological necessity, war as the habit of all nations that are not spiritless and exhausted, war as giving the only stage on which man may play his highest rôle, war as the nurse of heroism, of magnanimity, of self-sacrifice, of all manly virtues-this is the language and these are the ideas by which men have been taught to think lightly of drawing the sword. Where the moral advantages and disadvantages are thus, to put it at the least, so evenly balanced, it seems a natural inference that national aims relatively slender should justify breaking the peace. Hence Bernhardi's plausible list, the need and possibility of expansion, the finding of an outlet for emigrants, the securing of markets, or even a state of unrest at home which the tonic of battle might allay. Has not such teaching been the best propædeutic for the Prussian military régime?

It is, of course, denied by the pro-German pamphleteers that their empire is organized in the main for any other purpose than peaceful development. But to the outside observer a hundred indications point another way. It is perhaps sufficient to refer to one-I mean the permanent predominance of the kingdom of Prussia in the councils of the empire. The Bundesrath deputies from elsewhere are not outvoted; they could not be, for they are a large majority; but they readily and even gladly yield. In forty-two years Prussia has never once failed to get her way, and German publicists speak of the chance that she may some day be defeated on a division as sure to precipitate an imperial crisis. Ask a German 
the reason for this, and he will tell you how much Prussia has done for the Confederation, how the other States had been in perpetual strife and perpetual insignificance, how the warriors of the north rescued and elevated the thriftless, dreamy folk of the south. In short, they acknowledge that they need Prussian control.

Whatever force there may have been in this forty years ago, one might surely suppose that Germany is now sufficiently stable to escape from tutelage. If half the boasts we hear are well-grounded, the Teuton should not be behind other races in capacity to manage his own affairs. Beyond doubt that capacity is present, and would be developed if the affairs to be managed were those of an industrial State; it is just because the main concern is war, actual or possible, that the section which excels in the field must guide those movements in time of peace which are so largely a preparation for a field yet to come. Consonant with this is the supremacy of the War Lord, the resistance to any scheme of what we call responsible government; by the Kaiser's will State officials come and go, whatever may be the support which the country gives to their policy or their administration. The underlying idea is that democratic control would be fatal to the type of empire which Germany aims to be. You see the same sinister principle in the "patriotic" teaching of school-children, in the worship of the army, in the eternal charges of majestas for the slightest disrespect to a man in uniform.

I do not feel called upon before this audience to enter into any reasoned refutation of the view that 
war as such is desirable, or even that it has so many advantages as to render its acceptance legitimate for national ends that are relatively slight. I should think that to argue at length against this would be to insult a moral consciousness which centuries of Christianity have gone to form. One might, of course, expose the nonsense about biological advantage to the race; one might point out how the very flower of a nation's manhood is cut down, how one sees perishing in a day what years of industrial effort will not restore, how the development of courage and self-sacrifice bears no comparison with the seething passions and unbridled lusts which are stirred into life. He will be a bold man who will revive this war dialectic so long as one can remember the fields of Ypres and the Marne-so long as a record lasts, not so much of what the agonized fugitives from Belgium have told us, as of the proclamations signed by German officers and posted on the walls of Liège and Dinant. That the Christian religion has been a great deterrent against such things in the past is a view which Christian men will accept from Nietzsche with peculiar thankfulness. Nor does our author stand alone among witnesses from his own country. Those were prophetic words of Heine in which he anticipated the hour when the German joy of battle would burst the bonds in which Christianity had long restrained it. "Then," he said, " the old stone gods will rise from the silent ruins, and rub the dust of a thousand years from their eyes. Thor with his giant hammer will at last spring up and shatter the Gothic cathedrals." It is with a sense of shame that one undertakes at this time of day to produce reasons against such a revival. 
That the land of such mighty industrial progress should have been led to see finer rivalries in bloodshed than in the arts of peace, that the land of Luther should have forgotten how much grander are the battles of the spirit than the battles of the sword, is a grim warning that a nation's soul cannot be fed through intellectual channels alone. "You taught me language," said Caliban, "and the profit of it is I know how to curse." Or we may sum it up in the pregnant words of St. Ambrose: Non in dialectica complacuit Deo salvum facere populum suum.

Let me now briefly sum up the grounds on which I claim that Nietzsche has helped to make his nation aggressive, unscrupulous, and tyrannical.

He wrote at a time of crucial decisiveness for the German character. Was victory to be used as a safeguard to peaceful development, or was it to be made a basis for further conquests? This was the moral choice which had to be taken, and, once determined, it would not be easy to go back. Should the policy of Frederick the Great be stereotyped for German statecraft? The real forces on the other side were considerations of justice, unwillingness to inflict cruelty and sacrifice life, respect for the rights of the weaker, solicitude for the human values which war must destroy. They were perhaps poor safeguards at the best-flimsy barriers when the bloodlust has been stirred. But, such as they were, Nietzsche taught all who would hear him to hold them in contempt. He told them that only a decadent, exhausted race would tolerate the equal claims of all to live and let live, that it was Christian superstition which made one reluctant to immolate the individual, 
that pity was a disguised blend of low-class revengefulness and disordered nerves. He spoke to a race flushed with victorious warfare about the intrinsic glories of war as such; he laughed to scorn all scruples about its darker side. He held before the imagination of a young virile race the great patterns of ancient Imperialism, and mocked the effeminacy of the Golden Rule. He argued with all the subtlety of his perverse genius that will to power was, in some form, the sole motive by which every race and every individual had in the past been swayed. He bade the Germans look forward, not with anxiety, but with a fierce joy, to the day when mankind would pass through a slaughter such as it had never known, when the petty politics of Europe's miserable nations would fade before a titanic struggle for the dominion of the earth. And all this was depicted as a new and higher morality, as the message of the modern prophet to whom alone men worthy of the name would lend their ears.

Was not this, as Sir Henry Jones has so strikingly put it, to " take the vessels of the temple and drink wine in them " ?1 How feeble in comparison with an impetus like this were those stray grumbles against the Bismarckian régime which are quoted to us as evidence that Nietzsche was a pacific force? And what must have been the effect as Germany went farther and farther in those military preparations which by his own declaration filled our author with joy? Europe became an armed camp; the ultimate issue between nations became, in Carlyle's phrase, "Can

${ }^{1}$ In Hibbert Journal, October, 1914, "Why we are Fighting." 
I kill thee or canst thou kill me?" Every country equipped itself with the most deadly weapons which skill could forge and the most powerful explosives which science could devise. Each treasury was drained to make the fighting machine more formidable; the special knowledge of the chemist, the deftness of the worker in steel and iron, the inventiveness of the aviator-all had to pay their toll to militarism. The Armageddon for which Germany's prophet watched and hoped was prepared for forty patient years by Germany herself. When the moment came, her statesmen showed none of the morbid humanitarian hesitation which he forbade; her university professors had learned his lesson about the exploiting rights of culture, her soldiers proved that they at least possessed the token of greatness which keeps a steady nerve before another's pain. ${ }^{1}$ I ask you, with your newspapers in your hands, whether the creed of Beyond Good and Evil has left no mark in the smoking ruins of Aerschot and the mangled corpses of the women of Dinant?

A few strident voices have been proclaiming to us that when this war is done with, England must draw the moral by immediate acceptance of conscription; she must place the War Office under the permanent administration of a soldier, the Admiralty under a seaman, and she must enormously increase her

${ }^{1}$ Cf. Joyful Wisdom, p. 325: "Who will ever reach the height of greatness if he does not feel within himself the power and the will to inflict great sufferings? ... Not to be shipwrecked on the rocks of one's inner distress and uncertainty when one is in the act of inflicting great pain and hears the cry of this painthat is great: that is an integral part of all greatness." 
Service Estimates. In short, she must take the first step on the slippery road that leads to where Prussia has gone. It is not the least of our British titles to -political insight that we have always kept such proposals at arm's length. Lord Kitchener saw very clearly and interpreted very faithfully the public temper when he spoke of himself as in the Cabinet for the duration of the war, as an extraordinary officer summoned for an extraordinary crisis. The Roman Republic in moments of peril used to arm its Consuls with dictatorial power, of which at the earliest moment they were divested: Videant consules ne quid detrimenti res publica capiat. We, too, are singularly fortunate in the possession of a soldier whose talents for the special emergency are combined with a loyal recognition that the army is the servant, not the master, of the people. If a man's trade is that of a fighter, he can scarcely help developing an outlook upon life which makes him a dangerous guide to a nation whose ideal is peace. We remember that ancient king of whom it is written that, despite his virtues, he could not build the temple of the Lord " because he had been a man of war." Those who mould humanity's future are architects of a temple more sublime than that of Jerusalem, and the best engineers of destruction are not the architects we want. Every profession has the defects of its qualities; what the defects of the military type may result in, Prussia is there to show. The outcome of this war for civilization no one need pretend to forecast; that the gracious Providence whose ways are wonderful, and who has so often brought good out of evil, cannot fail us now 
we may well believe. But so much as this we may be permitted to anticipate: when, by the mercy of God and the heroism of our troops, we have dethroned Siva in the Wilhelmstrasse, we shall not rebuild his blood-stained altar and recelebrate his blood-stained rites in Downing Street or Whitehall.

NoTE.-It is often said that the Germans were the last to develop enthusiasm for Nietzsche, and that his chief popularity so far has been in France. This statement is liable to mislead. The initial feeling in both countries may be largely explained by a single cause. However much one may sympathize with a philosopher's principles, one resents an accompaniment of personal insult, and it was only natural that France in the years immediately following 1871 should lend a ready ear to a German's abuse of Germany. But the public attitude of the two peoples rapidly changed. Regarding France, M. Paul Sabatier wrote long before the present war as follows: "His" (i.e., Nietzsche's) "influence has been as superficial as it was ephemeral. A recent investigation shows that the younger generation almost completely ignores him" (France To-Day: Its Religious Orientation, p. 94). M. Sabatier explains this abrupt eclipse as due to moral revulsion. Moreover, a chief complaint by Nietzsche against the Germans of his time was that they were too democratic, as shown by their acceptance of universal suffrage; he foresees a growth of Socialism, character-softening, and "herd-values." But he speaks of the chance that they may mend their ways and "become something." This was thirty years ago; might not a Prussian claim that the warning was taken? It is worth noticing that two or three months ago the Berliner Tageblatt reported a discussion in which Frau Förster-Nietzsche took part, and in which she rejoiced that the war had given to her brother his rightful place among his countrymen. 


\section{LECTURE VII}

\section{NIETZSCHE AND CHRISTIANITY}

WE saw at the beginning of our course that Nietzsche was the son of a Lutheran pastor, brought up amid the influences of a religious circle. No man ever broke away more completely from the environment of his youth. He was at first destined for the clerical profession of his father and grandfather; we have some fragments, dating from his boyhood, in which we can recognize the natural outlook of a coming village Pfarrer. "May God always have me in His keeping," he wrote before he had left school, and in his first years at the university he drew up a list of the sciences which he aspired to know, "especially," he says, "religion, the solid foundation of all knowledge." A theoretic interest in this subject he retained to the last, but his youthful devoutness became changed into a burning hatred to which the history of thought scarcely furnishes a parallel. It will be our task in this lecture to examine the spiritual attitude of a man in whom the creed of naturalism was cherished with all the fervour of a cult. I shall divide what I have to say into parts, taking first Nietzsche's theory of religion in general, and afterwards his special account of Christianity. 


\section{I.}

He begins by analyzing those causes which have led men everywhere to think along a religious line. Whence have come the ideas of God, of sin, of reward and punishment, of the clean and unclean soul, of an efficacious ritual, of a consciousness persisting after death? These he looked upon, somewhat unjustifiably, as the common counters of all religion, a language alien to man as Nature made him, hence requiring to be explained in terms of some later influence. His answer to these profound questions is very dogmatic and alarmingly simple; the ease with which they yield their secret to his scrutiny would have roused misgiving in a thinker less sure of himself, less confident in his own invincible penetration. His inquiry into the subject is purely psychological; that the ideas before him have any validity, any objective counterpart, is not for a moment entertained.

He assumes that to educated persons the whole spiritual fabric is, as Thucydides says of democracy,

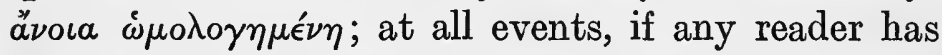
not reached this standpoint he is informed that the ensuing discussion is not for him. It is for those who know that the body is the reality and the "soul " a myth, that the determinants of action are physiological, that the " will " is but a name for that special passion which is for the moment uppermost, that no one is morally responsible for anything that he does, in any other sense than that in which an inanimate 
object is responsible for its obedience to mechanical law, that there is no purpose which a Divine Creator has fashioned the world to fulfil, that the whole of life is to be explained by a conflict amongst impulses rooted in the nervous system, and each an expression of will to power. The problem then is, How did such delusions as are involved in the religious view of the world become so widespread and so influential ?

Taking first the myth of theism, he finds its sources in the psychology of primitive man. Belief in God was part of a more general belief in the activity of spirits, unseen, but infinitely stronger than men, and this belief was suggested through the experience of sleep and dreams. ${ }^{1}$ By night, when the bodily senses were in abeyance, one was brought into contact with a new world, which, in turn, vanished when the sleeper awoke. Unable to interpret this in any other way, our simple forefathers took for granted a persisting reality all around them, which could be realized only when the common reality was shut out, and they were forced to think of it in the only category they had-namely, as the product of beings with a personality like their own. It was mysterious, it was associated with shadows and darkness, it came to them invested with all the terrors of the unknown. Thus, while they thought of spirits anthropomorphically, they also thought of them reverentially, and it was a short step to the notion of a Ruling Spirit, conceived in the likeness of human kingship.

This is, of course, a very common view of anthropologists, and as an account of how the idea of God historically arose it may well have an element of

1 Will to Power, 230. 
truth. Nietzsche held that although correct so far as it goes, it omitted a most important factor. Primitive man had been misled not merely by the visions of sleep, but by his crude reflection on his own waking states. His moods varied; and while he felt no need to explain the moods which were habitual, he demanded a cause for those which were strange, disturbing, especially for those which were " rapturous and overwhelming." 1 One could see this tendency still in the idea of obsessions and inspirations; epilepsy and lunacy had long been taken as evidence of some foreign agent by which the body was possessed; great poets and artists were looked upon as guided by a "Muse." The modern idea of a law of Nature fulfilling itself just as much in the ordinary as in the exceptional had not yet been born. Thus, early man saw no problem in the things which happened regularly, such as the return of day and night, or the order of the seasons, but in the things that were more or less fitful, like the thunderstorm, the onset of disease, the occurrence of death. He would be impressed less by the things which helped him than by the things which terrified him, less by the kindly sunbeams and the fertile ground than by the stroke of lightning or the shock of earthquake. In the same way he would attend to those conditions of himself which were markedly different from the common routine, conditions of exalted power whether for good or for evil; he would " explain" these by denying that he himself was responsible for them, by supposing an influx from a spiritual world without. The fallacy, of course, lay in thus belittling his native resources;

1 Will to Power, 230; cf. ibid., 135. 
nothing was understood of the endless variety-the ups and downs - of nerve action. But once the idea of a foreign agent had been accepted, there would grow up a set of fearful emotions; it would be thought of as an arbitrary power which must be appeased lest men should perish in the divine anger. Perhaps the most striking expression of Nietzsche's view may be found in a stanza of Shelley's Revolt of Islam :1

What is that Power? Some moon-struck sophist stood

Watching the shade from his own soul upthrown

Fill Heaven and darken Earth, and in such mood

The Form he saw and worshipped was his own,

His likeness in the world's vast mirror shown;

And 'twere an innocent dream, but that a faith

Nursed by fear's dew of poison, grows thereon,

And that men say that Power has chosen Death

On all who scorn its laws, to wreak immortal wrath.

The next important agent in developing religion is the rise of a priesthood. ${ }^{2}$ We saw in a previous lecture how Nietzsche explained priests as an element of aristocratic society, a caste which disputed the paramount claim of the noble. Once the myth of a soul and of a God had been diffused, it was easy to convince the simple that certain men were propitious media through which the supernatural world could act upon the natural. The contrast between flesh and spirit became accentuated; the body was depicted as the enemy of the soul. Hence the vile superstition that men of low physical vitality, pale, anæmic, world-denying creatures, were favourite channels of grace; it was these whom the gods would choose to

1 Canto viii. 6.

${ }^{2}$ Will to Power, 138 f. 
" inspire." The ascetic priest thus secured a weapon of matchless effectiveness in his struggle for domination over the "herd." This is one of the things that Nietzsche has in mind when he uses that paradoxical phrase: "Ascetic morality as a form of will to power." In this way men were persuaded to set the highest value upon qualities which were most opposed to healthy physical instinct. "If the priest is to be the highest type, then the degrees which lead to his virtues must be the degrees of value among men. Study, emancipation from material things, inactivity, impassibility, absence of passion, solemnity." Thus, by its very nature the rise of a priesthood is at once a symptom and a cause of decadence. ${ }^{1}$

The sacerdotal class has still another weapon, and Nietzsche finds that it has always employed it in a way which confirms his estimate of religion as degeneracy. If a mediator between God and man is to secure his authority beyond challenge he must represent himself as holding a monopoly both of spiritual action and of spiritual truth. He is at once the way of approach to the Divine and the sole interpreter of the Divine reality. Hence he must manufacture a code of religious duty, separate from the ordinary rules of conduct between man and man; the fulfilment of this code must be made to depend on his own priestly functions. And he must enjoin the acceptance of all that he communicates ex cathedr $\hat{a}$ as an oracle of God. This means the creation of a religious "conscience",- - a distinction, not between what is good and bad, but between what is clean and unclean-in a word, a ceremonial law. It means, 
further, the investment of doubt or disbelief with a character of moral heinousness; the heretic becomes the sinner par excellence. Nietzsche appeals for evidence of this to the history of religious Europe, to the vast machinery of the Church's penal legislation.

Nor will he allow that priests have been in any degree honest in the part they have played; he will not concede that they have been themselves the dupes of the superstition they have propagated. The thing has been deliberate, calculated fraud. "It is a mistake," he writes, "to suppose unconscious and innocent development in this quarter-a sort of selfdeception. Fanatics are not the discoverers of such exhaustive systems of oppression. Cold-blooded reflection must have been at work here."1 Thus, untruthfulness was the necessary weapon of all priests; their moral code sanctioned it, the very basis of their order involved the principle " that a lie be allowed in pursuit of holy ends." Nietzsche seems to have forgotten at this point that he has already contended that the one end is self-aggrandizement; he seems to concede that a lying priest must practise a sophistication upon his own conscience. But he proceeds to enumerate the things which "the holy lie has invented "-namely, a God distributing reward and punishment in accordance with the sacerdotal lawbook, an after-life in which these recompenses are carried out, a conscience trained to sensitiveness for religious distinctions, a morality which denies all healthy instinct, and a "Truth" to which priests alone have the key. 
Such being the foundation of them all, religions may be divided, in Nietzsche's view, under two types - the affirmative and the negative. By the former is meant a cult which supports, by the latter a cult which destroys, the natural gradation of men in rank and caste. Brahminism with its aristocratic code of Manu; Mohammedanism with its strict discipline in the Koran, and its avoidance of all effeminacy; or even Hebraism in its earliest Old Testament form, may be cited as examples of religious affirmation. Buddhism and Christianity were alike negative; each involved the denial and renunciation of life. But Buddhism was the superior, for it was the product of a ruling class, though that class had become exhausted and world-weary; Christianity, on the other hand, appealed not to those who had outlived their culture, but to those who were essentially below the possibility of culture from the first.

I do not propose to discuss this philosophy of religion at any length; our concern is with Nietzsche's moral outlook, and I have introduced his account of religious origins only because it is needed to explain his ethical point of view. Its merits will be lightly esteemed by the anthropologist on the one side, and by the philosopher on the other. The fraud theory, both in ethics and in religion, involves too much that is both incredible and unhistorical to satisfy those who investigate primitive peoples at first hand; and the dismissal of the whole religious problem on the basis of " primitive psychology" ignores the fact that the validity of a belief can never be decided by mere inquiry into the circumstances of its origin. In short, Nietzsche's view is simply a re-hash of undi- 
gested anthropology, together with some connecting links borrowed from a now obsolete Deism. There is nothing original in it, except the language of copious vituperation in which the whole is clothed.

II.

Having thus accounted for religion in general, Nietzsche faces the question: "What is it that has made the Christian religion such a force among men?"

This problem fascinated his thought at a very early stage. A short time at the university had sufficed to dispel the trustful faith of his boyhood; he soon became convinced from the intellectual standpoint that Christianity implied a system of illusions, that there was no intelligent ground for belief in Providence, in an Incarnation, in an inspired Scripture, in a world to come. More than this, he became assured that these doctrines were not only unsupported by reason-they were contrary to reason; his position passed from one of doubt to one of militant and aggressive denial. But one feature in Germany's religious attitude specially perplexed him. There were, of course, plenty of writers who shared his negative view. There was Strauss, for example, from whom he had learned much of the rationalizing spirit. Yet we find that one of Nietzsche's first books is a polemic against Strauss of the most vigorous and even violent type. A coward, a timid thinker who stops half-way, a weakling afraid to face public opinion-these are some of the terms in which he assails the man whose position was so similar to his 
own. What prompted this? The answer takes us far into the heart of our subject for this afternoon.

Nietzsche was an odd mixture of qualities; but he was above all things an intense soul, determined to follow truth as he saw it wherever that truth might lead, whatever cherished feelings it might outrage, whatever sacrifices it might entail. There is much in his teaching well fitted to make others deceitful; in personal character he was himself compellingly, even intolerantly candid. He has said many a time in one place things which we can see him to have contradicted in other places; but, so far as he knew it, he has striven to be faithful to one conception throughout. And what he aimed at himself he imperiously demanded in others; he could stand no dissimulation, no hesitancy in pressing to its last outcome a principle which had once been embraced.

Now, one principle which he had embraced was disbelief in God, and it seemed to him that from such disbelief consequences of immense moment must follow. Over and over again he dwells upon the epoch-making nature of such a thought. But yesterday men had trusted in a Divine Spirit whose name was Love, caring with fatherly tenderness for all His children, counting the hairs of our heads, without whom not a sparrow falleth to the ground, making all things to work together for good. To-day men knew that the world has no guidance, that its principle is not love but remorseless warfare, that the individual is of no importance, that there is no wisdom and less mercy by which human affairs are shaped. The first conception had developed itself into myriad consequences in the Europe of the past; from it had 
come man's sense of sin, his craving for redemption, the whole way of life enforced by the Churches. It had entered into the very fibre of civilization; it had been honoured in countless rules of social conduct. The second conception, if we were honest with ourselves, must dominate the civilization of the future; it must sweep away a mass of false homages, it must replace them with the aims that are dictated by the clearer and truer outlook upon fact-in short, the very engines of society must be reversed. And yet David Strauss, who could not fail to see this, had stopped short with reciting the new creed; he was not man enough to brave public obloquy and point the way to the new practice. "The greatest modern event," said Nietzsche, "is this, that God is dead; yet those who know it go on precisely as if nothing had occurred."

To this extraordinary situation Nietzsche again and again returns. On one side the demolition of Christianity seemed complete; its central tenets had been consigned by fearless criticism to the place which was justly theirs, a place among the myths and dreams of mankind's infancy. But there still survived a moral system which stood in a curiously reciprocal relation to the dogmas that had vanished. Men had ceased to believe in God, in Christ, in a future state, and yet they could continue to cherish the Christian notions of human brotherhood, of good and evil, of duty and responsibility. It was a strange paradox of thought, for the two systems of ideas were interwoven together-together they had stood through the shock of the centuries, together they ought plainly to have fallen. Nevertheless, those critics who were most 
remorseless towards Christian theology were often enthusiastic towards the Christian ordering of life.

Sometimes Nietzsche thought it might be accounted for by mankind's lack of logic. We give up the foundation on which our moral ideas rest, but those ideas themselves have become so entwined with our hopes and fears, our feelings and emotions, so sanctified by the romance of the past, or so engraven upon the plastic characters of childhood, that they are able to stand though the supporting pillars are withdrawn. This at best could be only a partial explanation. Surely a man like Strauss ought to be capable of looking truth in the face, however intimate were the emotional ties that bound him to error! There must be some deeper source for the tenacity of the Christian values. That source he believed himself to have detected. To put it in a word, Christian morality had survived Christian dogma, because it was not the dogma which at first won acceptance for the morality; it was the morality which won acceptance for the dogma.

Why, he asks, did men so readily believe that mass of incredible propositions which constitutes the creed of the Church? It was not enough to show that these propositions contradict reason. We must explain why, being thus irrational, they have not by this time been universally repudiated. The secret, he tells us, lies in this:-

Christianity arose in a pagan world, where the conflict of classes was becoming acute. Its birthplace was in a subject people; the Jew was Nature's plebeian, the Roman was Nature's aristocrat. Nowhere else do we see with such concentrated intensity the 
hatred of him that is low against him that is high. "One divines it," says Nietzsche, "by a thousand indications, but it is sufficient to call to mind the Apocalypse of St. John, the wildest of all written outbursts which the revengeful conscience has manifested." On the one side the governing circle, that upper order of mankind which had the virtues of rulership, dominance, nobleness; on the other side, the masses who were governed, the ravenous proletariate, weak, submissive, servile. In paganism's golden age each class kept its own place; the natural barrier was preserved. But the social ferment in Judæa had baffled a succession of procurators, and no matter what religious alias it assumed, the movement at bottom was one and the same--an insurrection of the slave against his master. There was at the same time throughout the world a singular receptiveness to all manner of weird superstition; the old faith had gone, that patrician faith which had sustained Roman gravitas and Roman dominion, and there had come into its place a swarm of Oriental cults drawn from the ends of the earth-Magna Mater from Pessinus, Serapis from Egypt, Mithra from Syriaall, however crude their dogma and however absurd their ritual, were welcomed by the infinite credulity of minds that could not live without a cult.

To a public filled with revolutionary discontent the Galilean message was first proclaimed; to a public ready for any superstition it quickly spread. It hit the mood of the moment, for it addressed itself to the multitude, and it told the multitude the things that were most congenial; it spoke to them of human equality, of the tyranny which the rich maintained 
over the poor, of a Paradise in which they should be " eternally indemnified" for the wrongs of earth, of a God who would be the proletariate's champion, of the peasant's "treasure in heaven" one day to be inherited by the soul that could never die. To such feelings the appeal came home with overwhelming power; it was because it promised revenge against the upper classes to the poor man, to the outcast, to the slave, that minds at once simple and passionate accepted the whole supernatural apparatus of Christianity. "The Christian and the anarchist are of the same origin. . . Their object, their instinct, is wholly destructive ... they are both decadents. ... Christianity was the vampire of the imperium Romanum -in the night it undid the immense achievement of the Romans of obtaining the site for a grand civilization." This is what Nietzsche means when he insists that the kernel of the religion of Europe lies in its moral system; its dogma is but the intellectual reinforcement of its view of life. Just because those communistic passions on which it worked at the beginning are mighty with the multitude to-day, Christianity is still the faith of the masses. You may consume it any number of times intellectually, but if you leave the moral root it will spring up again and again from its very embers.

Now, there is one respect in which this monstrous psychology contained deeper insight than its author suspected. Nietzsche is right when he says that in the moral soil of our nature Christianity has its last and surest hold. He is right when he claims that reversal of the moral values would strike at the very heart of faith. He is right when he makes our creed 
rest on our conscience rather than our conscience on our creed. If you and I believe in God in any sense in which that belief is important, it is not because we have bowed before the cogency of an argument, it is not in virtue of the intellect's submission to a syllogism. No doubt the objects of faith can and should be presented in such a fashion as to be rationally credible. The mind's perplexities are often a cloud concealing from the soul the vision which it craves. But, when the cloud has cleared, it is the eye that sees; the fairest landscape has no beauties for the blind. Arguments from design may silence doubt; evidence from miracle and prophecy may constrain a barren acknowledgment of things which the reason cannot subjugate under law; psychic phenomena may leave us no intellectual option but to admit a spiritual world. None of these acquiescences constitute faith; it can live without them, and it can languish where they are most abundant. But the conscience that is sensitive to duty, the feelings which cannot bear the manifold injustice of a mechanical universe, the will that demands somewhere and somehow satisfaction for its highest ideals and its deepest intuition-this is indeed the spirit that is attuned to the Galilean gospel. Not through coercion of the mind, but through winning of the soul, has Christianity worked in all ages. Our final outlook upon life has its roots planted in " profounder strata of our nature than any mere tillage of the intellect can reach." This is one of the reasons why the poet and not the scientist has been the herald of religion. "Truth," says Wordsworth, "is ofttimes nearer when we stoop than when 
we soar." And you remember how the long argument between faith and doubt in Tennyson's "Two Voices" concludes with a burst of assurance deeper than aught which reasoning could yield:

Such seem'd the whisper at my side:

"What is it thou knowest, sweet voice?" I cried.

"A hidden hope," the voice replied:

So heavenly-toned, that in that hour

From out my sullen heart a power

Broke, like the rainbow from the shower,

To feel, although no tongue can prove, That every cloud, that spreads above And veileth love, itself is love.

Over and over again, if Nietzsche had had the patience and discernment to see it, this grounding of belief upon moral intuition is proclaimed in the Christian literature: "With the hearing of the ear have I heard of Thee, but now mine eye seeth Thee;" "With the heart man believeth unto righteousness;" "Thou hast hidden these things from the wise and prudent, and hast revealed them unto babes."

My second remark about Nietzsche's religious attitude is to give him all credit for his impatience of halfmeasures. He was absolutely right in his insistence that the man who has overthrown belief in God, if he stops there, has said either greatly too much or greatly too little. Let him either go back or go forward. You either believe or do not believe in a providential order; make your choice, but when you have made it, why not follow it out to its last consequence? It is against the notion that such a change makes no practical difference that Nietzsche levels 
the scorn of an honest mind. He was an enthusiast; whatever ereed he had adopted, that creed he must bring to bear through and through, making no compromise with public prejudice. "An atheist by religion," someone has ealled him; the same fervour which others devoted to their faith he devoted to his. I am often reminded in reading Nietzsche of those striking sentences in Wilde's last book:

"I would like," he says, "to found an Order for those who cannot believe-the Confraternity of the Faithless, one might call it, where on an altar on which no taper burned, a priest in whose heart peace had no dwelling, might celebrate with unblessed bread, and a chalice empty of wine. And agnosticism should have its ritual no less than faith. It has sown its martyrs, it should reap its saints, and praise God daily for having hidden himself from man."'1

Nietzsche thus cherished a burning purpose; he would disentangle life from every shred of the Christian superstition. To do so he sets in high relief those respects in which, in his view, the Christian influence has been despicable.

Recall what I said a moment ago about those moral feelings which make a soil receptive to religion. We think these feelings the surest gateways to truth; Nietzsche thought them the deadliest channels of error. We think that Christianity appeals to man at his best; for Nietzsche it appealed to him at his worst. It will be convenient to sum up the reasons for this under three heads; they correspond to three marks of "nobleness" which, as it seemed to Nietzsche, the Christian ideal contradicted. 
1. In the first place, he thought of the "noble" spirit as one that believed in its own instincts. Life was intensely worth while, intensely worth living; but it was so only to those who were fit for it, to the enthusiastic "once-born" men, 1 who had eyes to appreciate the greatness of their own theatre of action. He who was in the world but not of it, he who kept up an eternal protest against the scheme of things, rebellious against the order without, and contemptuous toward the ardent impulses in his own breast, was a decadent, a degenerate-one, as Nietzsche puts it, " of whom the earth is weary; away with him !"' Such a man might get, like Schopenhauer, a morbid pleasure from his morbid thoughts; he might be like the old cynic in Wordsworth's Excursion, ${ }^{3}$ who

wastes the sad remainder of his hours

In self-indulging spleen, that doth not want

Its own voluptuousness; on this resolved,

With this content, that he will live and die

Forgotten, - at safe distance from a world

Not moving to his mind.

But such persons who sat in judgment upon life were the mere waste and wreckage of humanity; healthy spirits were joyously responsive to the forces around; they welcomed human nature unexpurgated. The soul, like the body, must find its well-being not in restraint but in free passionate expression. Let the watchword of the new order be abundant vitality, bounding instinct, the red blood of youth.

1 I borrow this striking term from William James's Varieties of Religious Experience.

2 Zarathustra: Prologue, 3.

3 Book ii. 
2. Again, Nietzsche thought of the world's greatness as being the very reverse of uniform, placid contentment, in which everyone should enjoy a bourgeois ease; for it was the greatness of struggle, the higher ever mastering the lower, and being in turn mastered by what is higher still, a remorseless yet an entrancing view of agelong conflict in which the noble fights its way against the mean. ${ }^{1}$ Nihilism sprang from fixing one's attention on the fate of individuals, from incapacity to rise to the purpose of the whole. Hence the futile inquiry: "Is the world a happy place?" The lofty spirit looked on happiness as an aim for beasts; utilitarianism was but a reminder that we are come from the worm and the ape, and that much of the worm and the ape is in us still. ${ }^{2}$ Not a happy life, but an heroic life was the ideal. ${ }^{3}$ And if this ideal was to be realized it must be through glad acceptance of the thought that pain and pleasure as such are as nothing, that the immolation of the individual is the price humanity must pay, that the ascent of man can be achieved only through the suppression of multitudes of men. Let the new criterion of virtue be one's readiness thus to sacrifice himself upon the altar of his race.

3. In the third place, Nietzsche thought of a coming end to the whole, when the conflict which had known no pause and the sifting which had known no mercy

"Cf. the conception of higher man as "living dangerously": " he should experiment with himself, and run risks with himselfng beautiful soul-quackery should be tolerated " (Will to Power, (951).

${ }^{2}$ Zarathustra: Prologue, 3.

${ }^{3}$ Schopenhauer as Educator, sect. 4. 
should have at length evolved the ideal. Perfect in physical and mental strength, through and through a child of earth, yet able as no children of earth had yet been to drain the cup of earth's possibilities, the Superman would stand out almost like a new species of life; capable, proud, self-reliant, fit for everydemand that Nature could make upon the responsiveness of body and of spirit, he should feel that in his person the race, reaching its topmost limit, had transcended its very nature.

Now, Christianity, in Nietzsche's view, had denied each of these aspirations in turn. It had denied the grandeur of the world, for it taught men that their natures were corrupt, their robust passions were sinful, their highest efforts were worthless, their very righteousness was as filthy rags. It had spoken of a rebirth in which all that the true man valued must be left behind, and all from which his instincts revolted must be wrought into his character. The name "world," so dear to the healthy pagan, had been changed into a term of reproach; ${ }^{1}$ in hymn and prayer and ritual the Church had kept before one's mind the thought of a salvation which meant renouncing the world with its affections and lusts, of a citizenship not here but in heaven, of a friendship with the world which was enmity toward God. Paganism had said "Yea," Christianity had said "Nay," to all that was natural." Under Constantine the Empire had been " converted," and was not the result writ large in the contempt of the body, the frenzies of asceticism, the cult of ugliness, the fear and hatred of knowledge-

1 Beyond Good and Evil, 195.

${ }^{2}$ Will to Power, 147. 
in a word, the darkness of a thousand years ? $1 \mathrm{Mr}$. A. C. Swinburne breathes the very spirit of Nietzsche when he writes:

Thou hast conquered, O pale Galilean; the world has grown grey from thy breath.

Again, Christianity had denied the heroic struggle of life, for it forbade the rivalry in which alone that which is noble can win its way. It cut at the root when it made a man a sinner for aiming at distinction, when it proclaimed all men as such to be equal. High culture meant a system of ranks, a full recognition that some are elevated, others low; its twin enemies were the anarchist and the Christian. The anarchist incited the mob to violence, the Christian worked more subtly but more surely, for he spread abroad the myth of a future state; he masked those natural inequalities which anyone could see behind the fiction that there somewhere sat an august tribunal before which all were alike. Immortality was the great invention of the priesthood, devised to invest the lower classes with artificial importance. Thus, Christianity had "appealed to all the cowardices and vanities of wearied souls "; far from being a new source of vitality, it was a growth that could proceed only in an exhausted stock. Let anyone look at the tragedy of Pascal, and he must be filled with anger against a creed that could so deform a noble spirit. ${ }^{3}$ Think of the foeda superstitio about an ugly body as the home of a beautiful soul, think of the fanatical but legitimate inference that sickness should at times

1 Will to Power, 154, 221, 250.

${ }^{2}$ Ibid., 252. 
be voluntarily induced! Contrast this with the pagan hero who, Prometheus-like, endures and challenges misfortune, ${ }^{1}$ with no grovelling thought about a spiritual "blessedness" which was higher than earthly heroism. Did not the whole stand exposed as an artifice by which the upper order might be forced to yield to the lower, the strong to forego their strength before the weak, the rich to impoverish themselves for the poor? To that end men had been taught a new vocabulary. In the workshop that fashioned Christian values, cowardice had been renamed " humility," powerlessness to resist had been called " forgiveness," enforced subjection had become dignified as "obedience." Thus, the strenuous competing world had been turned upside down. Could anything have been more subtly devised to paralyze the effort of those who have it in them to excel ?

And, lastly, the Christian ethic had denied the goal of life; for that goal, if it be worth reaching, meant a perfecting of the racial type; and such perfecting, by every law of Nature that we know, must involve elimination. From the Christian standpoint every life was of eternal value, the worth of each was precisely equivalent to that of every other; it was a lying eschatology that made the individual as such sacrosanct. Nature was " careful of the type, but careless of the single life"; hence Nature had brought types from strength to strength. Christianity, heedless of advance, concerned only for the comfort of the herd, had made an idol of the average man, had substituted a static mediocrity for an upward movement. The moment a society aims to be static it inevitably

1 Will to Power, 222. 
becomes decadent. And the back-wash of Christian ways of thinking had engulfed even those who ought to have risen superior to it all; even a Schopenhauer and a Strauss had been made to despair of humanity.

Thus, Nietzsche's indictment may be briefly summed up; the Christian morality is bad because it preaches pessimism, equality, and race decay.

Now, does it preach pessimism? Only in that sense in which, as it seems to me, pessimism must be the creed of every thoughtful mind. It declares that the world has much evil in it, evil of such a sort and of such magnitude that, in default of a cure, the world would not be worth preserving. Precisely the same view has appealed to many a keen thinker who had no Christian standpoint, but who has looked at life in the light of the great human values, and has simply stated what he found. To be a pessimist a man, as Nietzsche himself points out, does not need to say that the world contains on the whole more pain than pleasure. You may have other scales of valuation; whatever the thing is which you take to be the good for man-pleasure, virtue, knowledge, or a sum total of well-being in which these are elements-you are a pessimist if you conclude that the balance in regard to that thing is on the wrong side. Nietzsche, indeed, has devised a weigh-bridge which yields a positive result, but we have seen it to be a machine for evaluating the good in which the very meaning of good is falsified. And if one restricts his view to the facts of the natural order as we see it here and now, if one invokes no religious postulate, I can find no escape from pessimism for him who sees life steadily and sees it whole. It is sheer subterfuge to speak of such 
a view as the outcome of an unhealthy or morbid temperament; it is rather true that the mood of placid satisfaction springs from the narrow outlook of a man who cannot see beyond his own circle. "What's wrong with the world ?" asks Mr. Chesterton. One thing wrong with it is that the one half doesn't know how the other half lives; if they did they could answer his question with ease.

Nor is Nietzsche in the least justified when he charges Christianity with inspiring an exaggerated sensitiveness to pain. It is true that the mild feminine virtues, as they are sometimes called, acquired higher value when pagan morality gave place to Christian. Respect for womanhood rose, and with it respect for the qualities in which women are or should be superior. There was a softening of manners; there was a new reluctance to hurt the creatures that God had made. But one hears with astonishment that the value of suffering was not recognized in a religion whose ideal was a Man of Sorrows, and whose symbol was the Cross. There are not a few passages where Nietzsche depicts the moral uplifting effected through pain in words which breathe the very spirit of the Saints, not a few which-incongruously enough -remind us of the warning that he who loveth his life shall lose it, and that through great tribulation the kingdom of heaven is to be reached. One cannot help feeling that in his enmity to the Christian ideal he has attacked it with arguments that answer one another. Sometimes he calls it grovelling because it exalts the weak, the ill-constituted, the sickly; at other times he calls it morbid because it cannot find room for the element of pain. 
Thus, when Nietzsche speaks of the Christian contempt for life he is, in one sense, referring to that which both exists and is justified. It is not solely, or even chiefly, the lack of happiness that one has in view. Life has in it much that is sordid, motives that are vile, tyrannies that are intolerable, ambitions that are hateful, passions that are degrading. When we hear of original depravity, and of the flesh wherein dwelleth no good thing, we know what these lurid words stand for, and we know that what they stand for is real. Nietzsche meets such pessimism with a bold denial that the things it thinks evil are evil. The world as it stands is good enough for him, if only its scale were magnified; its pain, its disorder, its crime, are aspects of a grand æsthetic scene-let us enter joyously into the spirit of the whole. Such a view is, of course, inconsistent with all morality, with Nietzsche's own as much as with any other; if everything is good nothing is evil, and the very names good and evil become unmeaning. But what interests us at present is his charge that Christianity has so emphasized human worthlessness as to have produced a disregard of humanity's concerns, that it has concentrated thought on the concerns of an assumed other-world. Has it done so in any other sense than that of insisting that the concerns of life shall be viewed with a new seriousness, that the passions shall be controlled and the instincts guided? Have not the daily round and the common task thus become far more important than they could ever have been for one who thought of himself as a mere bundle of blind explosive impulses? Has not the spirit of brooding upon an after-life been discouraged by that 
meagreness of eschatological detail in which Christianity is so remarkable among religions? Is there any creed which emphasizes conduct so persistently, which so minimizes a mere performance of ritual, and so insists upon duty between man and man? If such an ethic has sometimes degenerated into a cunning calculation of consequences, into work with an eye to reward in future bliss, this is not the form in which it was enjoined by its Founder, and it is not the form in which it has since been preached by those who were most faithful to the Founder's spirit. One might fairly say that in no other system do we find so imperiously excluded that careless indifference which would call any part of man's life common or unclean. What we do find is that correction of the moral standpoint which was most sorely needed by the pagan conscience, and which the highest discernment of moral reason ever since has eagerly welcomed. There had been abundance of self-expression but little selfsacrifice, abundance of public spirit but little humility, abundance of culture but little benevolence and little restraint. These things, wrought by Christian influence into the fibre of conscience, have been found not to make the world less worthy but infinitely more worthy, not to debase society but to transfigure it. It is just for this that the New Testament morality seemed so complete to a philosopher of self-expression incomparably superior to Nietzsche; the maxim "Die to live" was for Hegel a perfect embodiment of the truth that the lower self must perish if the higher self is to be realized.

One feels in Nietzsche's references to this subject that what he generally has in view is not the ideal of 
the New Testament, but the practice of this or that section of the early Church. Sometimes he has in mind the Saints of the Desert, retiring from the world's affairs, anticipating every day the Second Advent, preparing to meet it through an austere ritual of prayer and fasting. Sometimes he has before him St. Thomas à Kempis, about whose book he seems unaware that Christian opinion itself is very various. "I can never," he says, "hold in my hand the Imitatio Christi without experiencing physiological resistance," a view from which I imagine many Protestant theologians would not dissent. Or, again, he is thinking of those who remained in the State, but refused to bear their part in its common work, the preachers who taught that a Christian cannot be a soldier, who encouraged an exaggeration of humility, and in doing so produced a self-consciousness, a spiritual pride which was the very reverse of the virtue they enjoined. Or, finally, he is inflamed by the Communists, the men who quote New Testament authority for a raid on their neighbours' goods. There is point in all these criticisms; amid the great upheaval of conscience which Christianity effected many a crude fanaticism took its rise. But for the correction of such fanaticisms nothing has been found so effective as a more thorough inquiry into the Christian ideal itself. Of such return to first principles Nietzsche has himself given an illustration, though in the judgment of every scholar a singularly unsuccessful one, in his effort to identify the changes introduced by St. Paul into the original teaching of Christ. But he constantly judges the Christian ethic, not by patient examination of what it contained. 
as inculcated by the Founder, but by a superficial glance at the expression given to it by this or that body of followers in their practice. It is enough for him that restraint of the passions was enjoined, and that anchorites mortified the body; it is enough that we are bidden to turn the other cheek to the smiter, and that some have refused to fight in any cause; it is enough that we are told of wisdom from the mouth of babes and sucklings, and that zealots have deduced contempt for learning. I confess myself unable to understand what is in the mind of those who admire Nietzsche's historical insight. What I observe in his work is the perpetual distortion of fact to suit a priori assumption. He discusses the growth of the Christian ethic with an ineptitude, a lack of historical sympathy, a failure to read literature in the light of the time and place of its origin, which if applied in any other field of research would render one's results practically valueless. Nor is it easy to preserve patience with a critic who so constantly imputes the most dishonourable motives to all who see a question differently from himself. Either theological prejudice or State-bribed subserviency is the invariable imputation. One must remember that he was equally dogmatic, equally careless of historical method, when he dealt with wholly secular problems; he never scrupled to bring a similar charge against thinkers as little disposed as himself to serve any interest but that of truth. One may ask, for example, whether it was religious terrors or Bismarckian largesses which forbade the philologists of Germany to follow him in his view that tragic drama was to be explained wholly in terms of music. 
Perhaps the clearest instance of what I mean is to be found in another charge which he has tabled, the charge that Christianity is in its essence hostile to freedom of opinion and to the growth of knowledge. "The Bible," he wrote, "opens with the story of God's mortal terror of science, Thou shalt not know." "nd he goes on, precisely in the strain of the crudest ighteenth-century Deism, to interpret this as a device of the priesthood for the maintenance of its own ascendancy. Intellectual doubt was made a sin, credulity became the first of virtues.

Now, such criticism is really not respectable at this time of day; it is parallel to the old explanation of the growth of Islam as secured by the sword alonethe very obviousness of both makes every thinking man distrust them. One can, of course, illustrate Nietzsche's case by many a sad chapter in the Church's history; many a fanatic has understood the Christian salvation as implying a surrender of reason, as obtained by submissiveness to dogma. But there is little to choose between him who estimates Christianity from the ecclesiastical corruptions and him who judges it from the immoral lives of individual Churchmen whom he knows. The argument about priestly cunning is one that we thought had been buried for ever with the works of Thomas Paine. It was surely the place of a philosopher, living in an age of historical progress, to ask how far this or that Christian spokesman had been faithful to the spirit of his religion, how far the things that he did were organically connected with the Faith that he professed. When Nietzsche attempts to base himself upon the text of Scripture his exegesis is so absurd in its literalness as to recall the 
old deduction of the Trinity from the words: "Let $U s$ make man in our own image." At the very time when he was writing his Antichrist many a writer in his own country was producing work which should have made that burlesque impossible. It was being clearly shown how salvation by dogma had travestied the Christian gospel, how great was the gulf between what Christ called " faith " and what we call " belief," how an attitude of will was elicited far more than a homage of the understanding, how religion has its root in judgments of value rather than in judgments of fact. In this way Christianity was being exhibited, not as a spiritual bondage, but as a spiritual freedom. I do not say that Nietzsche should have admitted this, but I do say that every competent critic of our time must take account of it, must shape his own view with such reconstructions before his mind. Of the great work of reinterpretation that was being done almost at his door by teachers like Albrecht Ritschl he shows not the least understanding.

Again, does Christianity preach that all men are equal ? Surely; and is not its message borne out by the conscience of mankind wherever that conscience has become developed? It is a slander on the pagan world to claim that such a thought belongs to Judæa alone. You get it clearly foreshadowed in the dramas of Euripides, in the Ethics of Aristotle, in the great Stoics, in the letters of Pliny, and in many another quarter that Tertullian had in mind when he coined the phrase: Anima naturaliter Christiana. GræcoRoman culture, to which Nietzsche so often appeals, can lend him at best a very partial countenance, and that rather in its practice than in its doctrine, for the 
best minds of heathenism were working toward the principle of human brotherhood.

But equal in what sense? For there are manifest differences of which note must be taken. We call men equal in that no accident of birth or place, of special circumstance or social opportunity, can override every man's intrinsic right to be equally considered with every other; they are equal in that each has an individual value apart from any use that can be made of him to serve a purpose in which he does not share. None can be another's property, none can be simply another's tool; this is that genuine individualism which is nowhere so explicitly repudiated as in the spurious individualism of Nietzsche. But does equality of this sort forbid competition? Does it not rather stimulate competition in so far as competition is healthy? It forbids the struggle in which one man's gain must be another man's loss, and it was because this element entered into the only sort of struggle which our author had in view that he would not hear of human equality. But it is an antiquated barbaric idea that we can only progress at our neighbour's expense. It is true of rivalry in warfare, it is true of the more sordid aspects of finance where warfare's crude injustice is reproduced, it is true of the conflict between nations for the material dominion of the earth. But there are higher fields than these, fields where every man's gain is gain for the whole. By emulation, as William James used to say, threefourths of the world's work is done, but it is emulation in the scientific laboratory, in the workshop, in artistic production, in inventiveness, in creative talent. Nothing could be more absurd than to suggest that a 
society organized in castes, in systematic subjection of rank beneath rank, is favourable to this sort of progress. It is rather fatal to it, as the stagnation of such societies has convincingly shown. For it means the depression of genius under iron barriers, it means the sterilizing of fields that might have brought forth abundantly. Nor is there the slightest risk that belief in the equality of mankind will obliterate or obscure the distinction of individuals. With all its faults our race has at least the quality of hero-worship; it pays a ready reverence to the men in whom it sees exceptional power, to its teachers in every province where teaching is of value. It recognizes the leadership of great poets, great statesmen, great thinkers, great artists; it realizes that the achievements of a Goethe, a Pasteur, a Darwin, or a Mozart, are works of no selfish ambition, but achievements for the world. It probably yields rather too much than too little homage to the men whose genius it is able to discern.

The truth is that metaphors from biology have become very dangerous in general thinking. Evolution has told us of the survival of the fittest, of the struggle for life, of the elimination of the weak. When Darwin used these phrases he had before him a single definite application; he was explaining the process by which animal and vegetable forms had been developed, and he saw that these figures were the most apt. He never attempted to push such formulæ into spheres to which they have no reference. If the misuse of biological terms has become the despair of clear thinkers on morality, if by this our ethical confusions have become worse confounded, the fault does not lie with Darwin; it lies with the smaller men who 
have caught up much of his language but little of his spirit. The primitive conflict by which man won his racial place contained many a repulsive factor which, we may thankfully observe, is not in its nature permanent; there was constant exploitation, constant supplanting, constant cruelty, but it is sheer dogmatism to assume that progress has just one law throughout, or that the same law has the same implications no matter how the material or the circumstances may vary. We have no evidence to prove this, and we have a great deal to disprove it.

Thus, while there is in Christianity much to forbid the competition which ignores justice, there is nothing to forbid, but much to encourage the competition which furthers culture. The man who thinks otherwise must have in view that which all developed morality, Christian or non-Christian, has long since repudiated; he must contemplate exclusive advantage for an individual or a group. Genuine progress implies improvement in the mild humane virtues; thus, in the absence of that influence by which such virtues are specially fostered, progress has commonly been hollow.

Finally, does the Christian religion promote development along a descending or along an ascending line? Is it an ethic of racial degeneration?

If what I have just said be true there can be only one reply. All depends upon the things you place at the top, and the things you place at the bottom of your scale of values. Do you admire individual strength, overweening, defiant, self-assertive, contemptuous of every interest but its own? If so, Christian morality will appear reaction, decadence, 
bondage. Do you admire, rather, the personality which "finds itself" just in proportion as other personalities are enabled to find themselves, which refuses any solitary goal, which is best satisfied when all that it has and all that it can effect are universally shared, which, in a word, can rest content with nothing less than this:

That not one life shall be destroyed

Or cast as rubbish to the void,

When God shall make the pile complete.

We are faced here with one of those ultimate differences of moral valuation which no argument can elucidate. He that cherishes one of these ideals need not dispute with him that cherishes the other, for there is no common measure to which they can appeal. Europe as a whole, on Nietzsche's own showing, has made its choice for the altruistic side.

Whilst, however, we stand, and are proud to stand, for the great human sympathies, we repudiate the thought that a man sympathetic in the Christian sense is one of lowered vitality, inferior in those qualities which flow from and minister to strength. We have not so misread the long tale of Christian heroisms; we have not seen there only the humility, the self-denials, the cultivation of a meek and contrite spirit. We have seen also the high courage, the proud sincerity, scorn of threats, tenacity of purpose, the commanding voice of the prophet, the " eagle eye " of the martyr. We have come, in short, to recognize that for all that is great in human impulses and resources a fuller and grander sphere is given by Him who said: "I have come that ye might have life, and that ye might have it more abundantly." 


\section{III.}

Nietzsche often derides Christianity as a "Buddhistic movement in favour of peace"; he suggests that those who submit to its influence will become too timid to face, if occasion should arise, the arbitrament of a battle-field, and that, if circumstance compel them to fight, they will readily succumb to a more virile non-Christian race. That a reluctance to draw the sword is one fruit of the religion of Galilee we have no wish to dispute. Our own ideal has long been peace, our affections have been set upon the things which only peace can foster, and we are convinced that herein we have done homage to the most sacred of national values. But have we not in these last months given the world a signal proof that such feelings, whose Christian source we gladly acknowledge, imply no lack of the sterner virtue which every people is from time to time called upon to display? Have we not before our eyes a striking crucial test by which the doctrine of religious enfeeblement may be judged ?

If Nietzsche is right the degenerative leaven should by this time have left unmistakable traces in the weakened morale of Europe. Men nourished so long on other-worldliness should have become apathetic to the things of value in life here and now; the emphasis laid for nineteen centuries upon kindness and brotherly love should have lowered courage and have intensified effeminacy; the thought of all mankind as equal should have cut the nerve of the pagan heroism that was fed by war, and the pagan progress that was 
maintained by rivalry. There is one place to-day where the morale of great masses of men is being tried as by fire, one place where surely no flaw and no weakness can escape detection. Do we find such tokens of lowered character upon the French and Belgian battle-fields?

I am not assuming any great Christian piety among the troops at the front; the passions to which war gives the rein are such as may easily darken such religious sentiments as a soldier feels. But we may grant, and gladly grant, to Nietzsche that in the character of the men from whom European armies are drawn-and I include the Germans not less than our own Allies-the influence of Christianity has made a difference. They come from countries where the Christian tradition is strong, the rank and file from that class which is least affected by new thinking. Whatever outlook upon life these men have, whatever grave thoughts visit their minds as they lie upon the bare ground, not knowing if they shall see another dawn, must come to them from the things they have heard in their churches at home or from their chaplains in camp. Many of them are tradesmen or artisans, farmers or clerks, or factory workers; the dull monotony of life's struggle has left them small room for what is called "culture," they have little time and less capacity for thought. But they have grown up in a certain atmosphere; there is one force at least which has stimulated their imagination and raised them above the cares of the immediate present. As Mr. Lecky has said: "Religion is the one romance of the poor." It is brought home to the very rudest among them with a refinement that belongs to nothing 
else in their daily round, for it has connected itself with the great events of their lives-their marriage, the baptism of their children, the burial of their dead. There is hardly one of them to whom these things are not impressive; however confused and however unintelligent be the way in which he regards them, they leave a mark which makes him to differ from a pagan. Now, as every clergyman can testify, it is just when a man knows himself in the near presence of death that these thoughts recur, however ignorant and however reckless has been his past. Conspicuous among them are the thoughts which Nietzsche derided as fit to ruin one's highest principle; to many a soldier the whole content of religion is acknowledgment of a God who in a life to come will reward the good and punish the evil, of a duty which means, above all, justice and good-will towards his fellow-creatures. Many and varied are the forms in which this idea is clothed. The Scottish Highlander as he recalls some fragment from the Psalms of the Kirk, the Guardsman from Yorkshire or Devon with dim memories of his Prayer-Book and clear memories of the churchyard where his fathers sleep, the Belgian with the crucifix by his side in the trenches, the Irish Catholic from Roscommon or Wexford as he pictures the Countenance his childhood long since adored in the Stations of the Cross, the Russian as he presses the icon to his heart and thinks he sees again the incense to the All-Father in the village chapel amid the snows of his home-all in their several ways paying a more or less ignorant and fitful homage at one holy shrine, all invoking more or less crudely in the supreme hour one gracious aid-do these men, I ask, compare 
unfavourably in all that we mean by courage and public spirit with Nietzsche's earth-loving pagan? Do they show the paralysis of other-worldliness? Do they blench at suffering? Do their commanders find that those of them in whom religious devotion is most ardent are the least to be trusted when the moment comes to " do all that may become a man"? Is not their loyalty to the trust that their king has given them made all the surer if they feel themselves in the presence of a higher King, charged with a responsibility such as no earthly State can impose? Was not the psalm and prayer around Cromwell's camp-fire a grim omen for the enemy on the morrow? Have we not proved on many an awful field that there is no arm so strong to smite as the arm that is nerved by Faith, no civic spirit so intense as the spirit that looks to a more abiding city, no courage so enduring as the courage that sees Him who is invisible?

There is another line of thought which must have suggested itself to most of us as we have been endeavouring in this course to compare Nietzsche's view of life with that of the Christian civilization in which we have been educated. One may ask: "What difference does it make whether we are theoretically Nietzscheans or theoretically the reverse? We are confronted in practice with a spectacle as savage, as blood-stained as any that the world could have produced if no man in it had ever heard of Galilee and its morality, if every soul had been nourished on the creed of "will to power." Many a sombre reflection will occur to the thoughtful minds of the future as they remember the Europe of 1914. Many a daring 
general inference will be hazarded. And the word that will rise most easily to the lips of some will be this, that the moral failure of Christianity has been demonstrated, for the Faith which began amid angelic songs of "Peace on earth, good-will toward men," had made trial of its power for twenty centuries; it had been cherished with apparent devotion by the Western nations, and it conducted them at the close to the most extensive and relentless slaughter in the history of the race. I should like to use the short, time that is left to me in looking at this fearful situation from a point of view which is suggested by the principles upon which I have dwelt.

To those who believe in the moral value of Christianity the scene before us is, of course, full of humiliation. We are disappointed, deeply and bitterly disappointed. We trusted that such a thing to-day could not have taken place, that the leaven of the Faith had penetrated too far into the fibre of Europe. That is the obvious reflection, and I need not draw it out; there is another and a more cheering side, especially when we look at it, as we should, from the standpoint of Great Britain, and ask ourselves whether the part that we have chosen is a part worthy or unworthy of the moral professions we make.

The longer this war lasts the more completely do we forget those political quarrels in the Near East by which it was originated, or at least occasioned, quarrels about which it may be that honest difference of opinion is possible. For what impresses us more clearly every day is that the conflict has become a conflict between ideals, between two rival conceptions 
of life, conceptions and ideals avowed without the slightest hesitation or ambiguity on one side and on the other. I invoke here no debatable evidence, no doubtful or ill-attested gossip circulated in this interest or in that. I rely upon no controversial diplomacy between Foreign Offices, through which the lay mind cannot be expected to thread any certain or confident way. I appeal simply to the explicit declaration of Germany's moral principles in statecraft, to the basis of her policy as affirmed in her press, in the official speeches, in the most influential literature. The men who are opposing us in the field stand, by their own avowal, for the rights of main force against peaceful arbitration, for the intrinsic glories of conquest, for the crushing of small nationalities, for calculated brutality on the battle-field. To put it very roughly and summarily, they stand for Nietzschean immoralism against Christian restraint.

This is the issue that has come to dwarf every other in our titanic struggle; it is this which has roused the spirit of war in those leaders of opinion throughout the churches of England, many of whom have spent a long life in the advocacy of international peace. Not to settle any racial feud in the Balkans, not to take territory or trade from one and to give it to another, but to hold the fortresses of Christian humanity and Christian justice, we have sent forth to France, to Belgium, and to the high seas, men who in such a cause count not their lives dear to them. We stand, indeed, at a thrilling juncture in the history of mankind, the juncture foreshadowed all unwittingly by the poet who cried: 
Oh, that the words which make the thoughts obscure

From which they spring, as clouds of glimmering dew

From a white lake blot heaven's blue portraiture,

Were stripp'd of their thin masks and various hue And frowns and smiles and splendours not their own,

Till in the nakedness of false and true

They stand before their Lord, each to receive his due."

Now, I wish to say no disrespectful word of those who honestly believe that under any provocation however severe, and for any cause however sacred, recourse to arms is contrary to the mind and will of the Founder of our Faith. I shall say, however, that such is not my reading of New Testament morality. On the contrary, I find in it no principle more fundamental than this, that there are evils to be feared more than we fear physical suffering, that there are causes which at times must be maintained even unto blood. Let us not forget who it was that said: "Think not that I am come to send peace upon earth;" who it was that spoke of the day when he who had no sword must sell his garment and buy one.

Will anyone dare to say that the men who fifty years ago laid down their lives on the battle-fields of America, that they might free the body and raise the soul of the negro, lacked the benediction of the Prince of Peace? Or that such a struggle was not far more a triumph than a condemnation of the Christian morality? There has, I grant, seldom been a cause of warfare so pure, so disinterested, so irreproachable, that it would not seem poor if named side by side with the great impulse which stirred the heart of Abraham Lincoln; but we venture to believe that the enterprise to which we have set our hands will bear even the fierce light of that comparison. I read 
some time ago in a newspaper which boasts of its public spirit that we are fighting to compel the German flag everywhere upon the seas to yield obeisance before the Union Jack. Perish the thought that for such an object our country is pouring forth the blood of her sons! It is not the flag that sanctifies the cause, it is the cause that sanctifies the flag. Not for the Union Jack, dear to us though it is, but for the things which the Union Jack symbolizes-for equal rights, for the franchises of mankind, for justice and freedom and public law, and the sanctity of the plighted word - things that are not ours alone, but the precious birthright of humanity of which an armed usurper would despoil us, things for which it is our proudest and our purest boast that as a nation we have aimed to stand. Aye, for these, and for the whole scheme of duty proclaimed nineteen centuries ago upon the hillside in Galilee, the spirit that breathed upon a dying paganism the very breath of life, the spirit which has created all that we value most in civilized order, the spirit to which we are often indifferent and often disobedient, but which in our deepest nature and at our best we adore, the spirit whose meaning never came home to us with such overwhelming power as when we were challenged to do battle for its sake. Looking at it in this light, coming generations will, I am sure, see in this war something more than the blood-lust of armed hosts, something higher than dark passions and reckless greed. They will see in it that which reminds them of the old heroisms and the old martyrdoms; they will see nothing to contradict but much to illustrate the Christian spirit in men who turned a deaf ear to 
the self-interest of the moment, who remembered the things for which one should even dare to die, who risked all for what they counted worthy of all risk. They will recognize, not with shame but with surpassing pride, that to their ancestors the call came to sacrifice their lives for that which is more precious than life, and that when the call came it was met.

The cynic may remind us that the past has seen many a war described as a "holy" war, that the fights which involved religion have been the worst of all. There is truth in this, just as there is truth in that other biting epigram that more suffering was caused through Ferdinand V.'s loyalty to his fanatical conscience than through Nero's indulgence of his lusts. These are the dark ironies of history, and let him who will find a satisfying moral in the thought that mankind is but the sport of a malicious and satirical fate; let him who will sum it all up in the words of Omar:

But helpless Pieces of the Game He plays

Upon this Chequer-board of Nights and Days;

Hither and thither moves, and checks, and slays,

And one by one back in the Closet lays.

This at all events is not the moral that appeals to the eye of faith, nor is it the moral that is seen by the man who believes that through fidelity to the right, as one understands it, no matter what may be the suffering involved, lies the world's only pathway leading upward.

When Peter the Hermit called Europe to a holy war against the Saracen, he wrought upon the imagination of simple but heroic souls who could not bear to think that profane feet should trample and profane hands 
should desecrate the sepulchre of Him who had redeemed the world. That spirit did not lack its nobleness, though in the light of a wiser age the purpose seems unworthy of the devotion. Amid the horrors of Europe to-day we may discern the same impulse working with a clearer vision, the vision that the holy things we must defend are no local sanctuaries, but the life-giving principle which was there enshrined; no objects that can be seen or touched, but the spirit of which the Tomb at Jerusalem is an abiding symbol. We trust that when it is all over mankind will have seen the last great challenge of might against right, and will recognize that to men of British blood it was given to go forth in that final issue, counting not the cost. 


\section{INDEX}

ACTON, LoRD, 151

Altruism, 50 ff., 68-72, 80-81, $104 \mathrm{ff}$.

Ambrose, St., 184

Anthropology, Nietzsche's incompetence in, $44 \mathrm{ff}$.

Antichrist, 26

"Apollonian spirit," 16

Aquinas, St. Thomas, 38

Aristocracy, 24; cf. $118 \mathrm{ff}$.

Aristotle, Nietzsche's view of his theory of tragedy, 17, 91, 218

Arnold, Matthew, 85

Asceticism, 9, 26-27, 40, 112, 122, 208-209

Bebel, Herr, 166

Belgium, 177-178

Benn, Mr. A. W., 59

Bentham, J., 87

Bernhardi, Gen. F. von, 105, 127, 149-152, 179, 181

"Bestowing virtue," 69-70

Biology, metaphors from, 220-221

"Birth of Tragedy," 16-18

Bismarck, Prince, 156, 166 ff.

"Blonde beast," 44

Bright, John, 179

Browning, R., 154

Bryce, Lord, 176

Buckle, 69

Burns, R., 115

Butler, Bishop, 78

Carlyle, T., 185

Chesterton, G. K., 212

Christianity, Nietzsche's attitude to, $1-2,12,30,40,66,73-74$, 135-136, 179 (n.), 181, $189 \mathrm{ff}$. See also Religion

Conscience, 37, $40 \mathrm{ff}$.

Conscription, 156, 186-187

Culture, contrasted with civilization, 160

German claims regarding, $171 \mathrm{ff}$.
Darwin, C., 92, 95 ff., 104 ff., 120 220

Darwin, Major L., 110

Decadence, 13, 19, 39, 60, 97-98

Deism, 217

Democracy, 28 ff., 142 ff., 190, 202

Dernburg, B., 149-153

"Dionysian spirit," 17, 18, 20

Effeminacy, 28, 212

Egoism, 50, 51, $67 \mathrm{ff}$.

Equality, 131 joint product of Christianity and herd-instinct, 134-136

" Eternal Return," 66-67

Ethics, inductive method in, $22 \mathrm{ff}$., $42 \mathrm{ff}$.

Eucken, Professor R., 154

Eugenics, 93 ff., 109-110

"European men," 156-157

Euthanasia, 65

Evolution. See Darwin

Feminism, 95

Förster-Nietzsche, Frau, $65(n$.

Franco-Prussian War, 166 ff., 173 174

Fraud-theory in morals, 22-23, $34 \mathrm{ff}$.

in religion, 48, $195 \mathrm{ff}$.

Frazer, Sir J. G., 47

Frederick the Great, 165, $174(n$.$) ,$ 184

French Revolution, 30, 69, 158

Garibaldi, 70

Garrod, Mr. H. W., 140

Germans, Nietzsche's estimate of, $161,171(n),. 173 \mathrm{ff}$.

Giddings, Professor, 46

Golden Rule, 71

Good and evil, a different antithesis from "good and bad," $23 \mathrm{ff}$.

Greeks, Nietzsche's view of, 13-14 
Greek tragedy. See " Birth of Tragedy"

Group-morality, 31 ff., 50-51

Guilt, 38

Happiness, 15, 65

Harden, Maximilian, 180

Harrison, Mr. F., 160

Hartmann, Edouard von, 6 (n.), 154

Harvey, Mr. Martin, 138

Hedonism, Nietzsche's attitude to, $10 \mathrm{ff}$.

Hegel, his system, 6-7, 214. See also Schopenhauer

Heine, Heinrich, 183

Herd-instinct, 30

Herd-morality, 28, 45, 50

Heredity, 119-120, 128-129, 147

Hobbes, T., 50

Honour, sense of, $136 \mathrm{ff}$.

Hume, David, 7

Immortality, 209

Individualism, 122-123, 155, 157 160

Instinct, 14, $52 \mathrm{ff}$.

James, William, 53, 206, 219

Jones, Sir H., 185

Jordan, Professor, 152

Justice, 86-88

Kant, 7, 32, 87, 123, 177

Kitchener, Lord, 187

Kosciusko, 163

Kulturkampf, Bismarck's, 169

Lassalle, 169

Lasson, Professor A., 172

Lea, Mr. H., 152

Lecky, W. E. H., 110, 224

Levy, Dr. O., 28, 146, 174 (n.)

Lichtenberger, Professor H., 43, $66,67,82,113(n), 123,$.

Lowell, J. R., 145

Ludovici, Mr. A. M., 96-97, 146

Luxemburg, 163

Macaulay,' Lord, 165

Mach, E. von, 152

Maine, Sir H., 46

Mandeville, 47, 110

Manu, Code of, 196

Marx, Karl, 169
Massinger, P., 128

Master-morality, 72 ff., 113, 133

Mencken, Mr. H. L., 26, 174

Militarism, 155-157. See also War

Mill, J. S., 58, 71, 72, 87

Moltke, von, 167

Mommsen, Th., 151

Moore, Mr. G. E., 88

"Moral axioms," $87 \mathrm{ff}$.

Morality, Nietzsche's account of its origin, $21 \mathrm{ff}$.

no first datum, but an artificial product, 34

different for masters and slaves, $72 \mathrm{ff}$.

as "interpretation, not text," 88

Napoleon, 69, 111, 159, 161

Nationality, Nietzsche's attitude to, $155,157,162 \mathrm{ff}$.

Natural selection. See Darwin

" Neue Moral," 33

Nihilism, 12, 19, 122, 207

Obligation, idea of, $34 \mathrm{ff}$.

Oligarchy, 134

Omar Khayyám, 231

Optimism, 9 sources of Greek, $16 \mathrm{ff}$.

Paine, T., 217

Pan-Germanism, 172

Pascal, 209

Paul, St., 215

Pessimism, its connection with ethics, 21, $207 \mathrm{ff}$. See also Schopenhauer

Philology, Nietzsche's use of, 12, 23-25

Philosophers, Nietzsche's view of the "academic chairs of virtue," $22 \mathrm{ff}$.

Pigou, Professor A. C., 103

Pity, $61 \mathrm{ff}$.

Plato, 109

Poland, 173

"Power," ambiguity in Nietzsche's use of word, 5 I

Pragmatism, Nietzsche's anticipation of, 122

Pride, 126

Priesthood, origin of, $26 \mathrm{ff}$. See also Religion 
Prussia, her historical policy, $165 \mathrm{ff}$.

her predominance in German Empire, 181-182

Psychology, Association School, 23,56

Nietzsche's weakness as psy. chologist, $48 \mathrm{ff}$.

Public spirit, 138-139

Punishment, 38

Quietism, 14

Rashdall, Dr. H., 80 (n.), 144

Realpolitiker, 176

Reformation, the, 158

Religion, Nietzsche's account of its origin, 29-30, $44 f f$. 135-136, $189 \mathrm{ff}$.

Responsibility, idea of, $36 \mathrm{ff}$.

Revenge, a plebeian vice, 29,130 , 201

Ritchie, Professor D. G., 89

Ritschl, A., 218

Rousseau, 34,46

Russia, 162, 175

Sabatier, M. P., $188(n$.

Salter, Mr. W. M., 63, 80

Sarolea, Dr. C., 158

Schiller, Dr. F. C. S., 14, 55, 123

Schopenhauer, his opposition to Hegel, 7, 8

his pessimism, 8,9

Nietzsche's attitude to, 8-12, $39,52,61,93,101,206$

Science, Nietzsche's criticism of, $15,120 \mathrm{ff}$.

Self-development, 76-80

Self-sacrifice, 67-68, 76 ff., 111 112

Shaftesbury, (3rd) Lord, 50

Shaw, Mr. G. B., 146

Shelley, P. B., 193

Sidgwick, H., 80, 111 (n.)

Simmel, Professor, 110

Slave-morality, $72 \mathrm{ff}$.

Social Democrats, 170

Socialism, 19, 98, 169, 202

Socrates, 13,16
Spencer, Herbert, 25, 49, 65, 105

Spencer and Gillen, Messrs., 45

State, Nietzsche's view of its origin, 34 ff., 46, 103, 156 . 157

opposed to civilization, 156

Stewart, H. L., 116

Stoicism, 69, 85, 91, 162

Strauss, David, 197-198

Suffering, 65, 75-76, 99, 212

Superman, $91 \mathrm{ff}$.

Swinburne, A. C., 146

Sybel, von, 151

Sympathy, 61 ff., 104 ff., 186 (n.)

Tennyson, 3, 204

Tertullian, 38, 218

Theism. See Religion

Theognis, 144-146

Thomas à Kempis, St., 215

Thucydides, 14, 190

Treitschke, von, 149, 151, 155, $157,166,171(n$.

Truthfulness, an aristocratic virtue, 24

different in masters and in slaves, 129

Tylor, E. B., 47

Tyrants, Greek, 146

Utilitarianism, 58

Values, theory of, 11-12, 21, $32 \mathrm{ff}$., $51-52,55,58 \mathrm{ff} ., 68,81-82,107$, $202 f f ., 211$

Wagner, 150

War, in general, 19, 98, 156, 161, $163,179,181,183,207,223$

the Franco-Prussian, 156

the present European, 2-3, $228 \mathrm{ff}$.

Wergild, 35

Westermarck, Professor E., 43, 45

Wilde, 0., 77-78, 205

Willamowitz-Moellendorf, 18

"Will to life," contrasted with " will to power," 25

Wordsworth, W., 206

Wright, Sir A., 95 


PNDING SECT. APR 291964

\section{PLEASE DO NOT REMOVE}

\section{CARDS OR SLIPS FROM THIS POCKET}

\section{UNIVERSITY OF TORONTO LIBRARY}


